Surface Infiltration and Unsaturated Zone Characterization in Support of Managed Aquifer Recharge in Bedell Flat, Washoe County, Nevada-
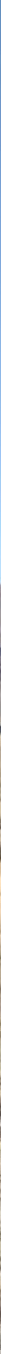

Scientific Investigations Report 2021-5137 
Cover:

Front. Bedell Flat in Washoe County, Nevada with Seven Lakes Mountain in the background, March 1, 2019. Photograph taken by Christian Kropf.

Back. Sunset in Bedell Flat in Washoe County, Nevada with Freds Mountain in the background, November 6, 2019. Photograph taken by Christian Kropf. 


\section{Surface Infiltration and Unsaturated Zone Characterization in Support of Managed Aquifer Recharge in Bedell Flat, Washoe County, Nevada}

By Todd Caldwell, Ramon Naranjo, David Smith, and Christian Kropf

Water Availability and Use Science Program

Prepared in cooperation with the Truckee Meadows Water Authority

Scientific Investigations Report 2021-5137 


\section{U.S. Geological Survey, Reston, Virginia: 2021}

For more information on the USGS - the Federal source for science about the Earth, its natural and living resources, natural hazards, and the environment—visit https://www.usgs.gov or call 1-888-ASK-USGS.

For an overview of USGS information products, including maps, imagery, and publications, visit https://store.usgs.gov/.

Any use of trade, firm, or product names is for descriptive purposes only and does not imply endorsement by the U.S. Government.

Although this information product, for the most part, is in the public domain, it also may contain copyrighted materials as noted in the text. Permission to reproduce copyrighted items must be secured from the copyright owner.

Suggested citation:

Caldwell, T., Naranjo, R., Smith, D., and Kropf, C., 2021, Surface infiltration and unsaturated zone characterization in support of managed aquifer recharge in Bedell Flat, Washoe County, Nevada: U.S. Geological Survey Scientific Investigations Report 2021-5137, 52 p., https://doi.org/10.3133/sir20215137.

Associated data for this publication:

Naranjo, R.C., Smith, D.W., and Caldwell, T.G., 2021, Documentation of VS2DH seepage models—Surface infiltration and unsaturated zone characterization in support of managed aquifer recharge, Washoe County, Nevada: U.S. Geological Survey data release, https://doi.org/10.5066/P9U905PC.

Smith, D.W., Naranjo, R.C., Caldwell, T.G., and O'Connor, K.E., 2021, Supplemental data- Surface infiltration and unsaturated zone characterization in support of managed aquifer recharge, Bedell Flat, Washoe County, Nevada: U.S. Geological Survey data release, https://doi.org/10.5066/P90AF8L8.

ISSN 2328-0328 (online) 


\section{Acknowledgments}

This study was supported by the Truckee Meadows Water Authority and the U.S. Geological Survey Cooperative Water Program. The authors wish to acknowledge Greg Pohl, John Enloe, Nicolas White, and Lauren Jones from the Truckee Meadows Water Authority for their assistance with the project. 



\section{Contents}

Acknowledgments ……...................................................................................................................

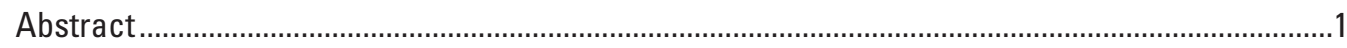

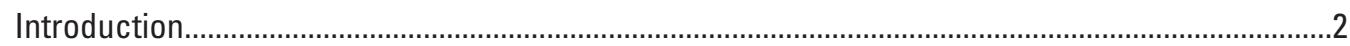

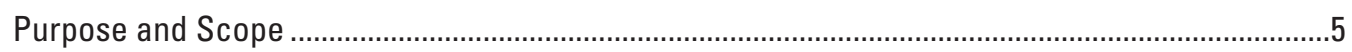

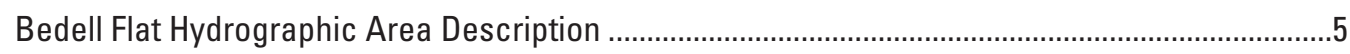

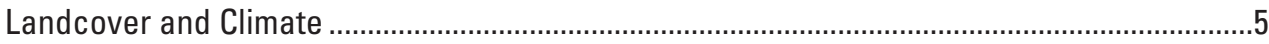

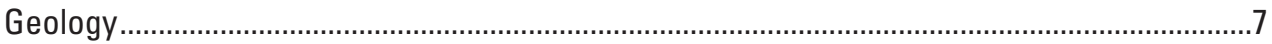

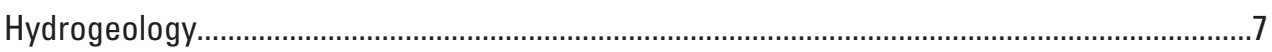

Existing Well Logs .............................................................................................

Aquifer Testing and Groundwater Modeling by the Truckee Meadows Water

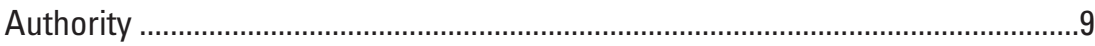

Methods of Investigation......................................................................................................

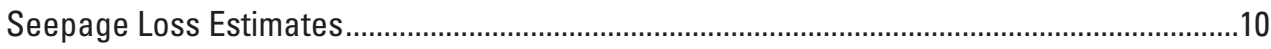

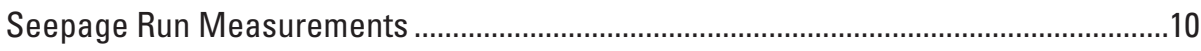

Flow Stage and Duration ......................................................................................... 10

Sediment Temperature at Transects ...........................................................................11

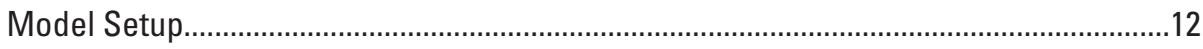

Model Calibration and Parameter Estimation ..................................................................13

Borehole Sediment Characterization ...................................................................................14

Field Characterization of Continuous Sediment ..........................................................

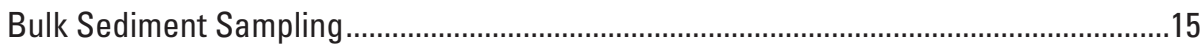

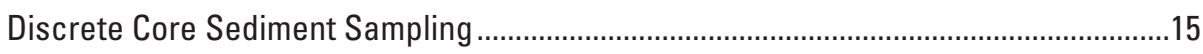

Laboratory Analysis of Sediments ..............................................................................15

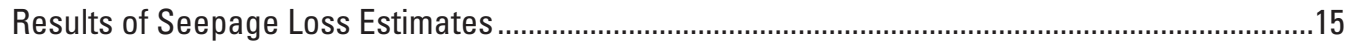

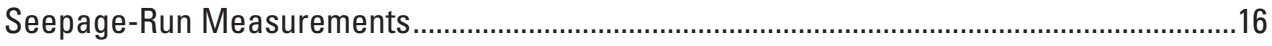

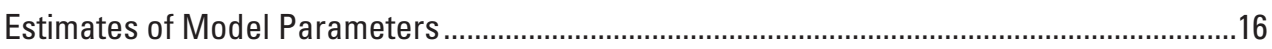

Seepage Loss Estimates at Transects using Calibrated Models..............................................17

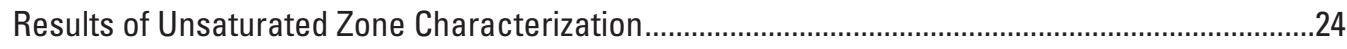

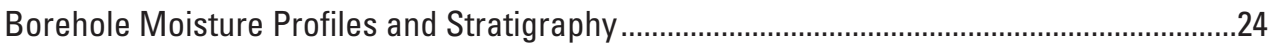

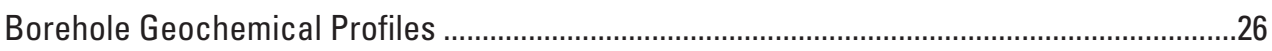

Comparison of Sediment Sample Collection Methods ...........................................................28

Conceptual Recharge Model for the Bird Springs and Sand Hills Drainages...............................29

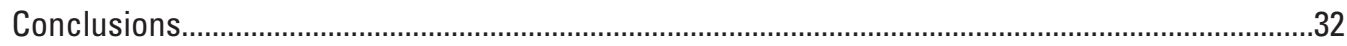

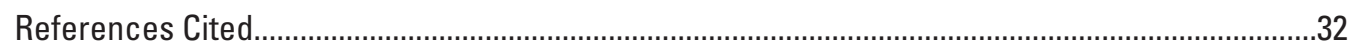

Appendix 1. Measured and Simulated Thermographs for Channel Sediments............................36

Appendix 2. Borehole Characterization Data …….................................................................41

Appendix 3. Chip Trays from Roto-Sonic Boreholes.................................................................4

Appendix 4. Field Procedure for Roto-Sonic Borehole Field Characterization..............................50

Appendix 5. Field Textural Lookup Table .............................................................................51 


\section{Figures}

1. Map showing the Bedell Flat hydrographic area in Washoe County, 30 kilometers north of Reno, Nevada...

2. Map showing the bedrock geology of the Bedell Flat hydrographic area and lines of equal combined thickness of basin-fill deposits and volcanic rocks.

3. Graphs showing the interannual variability in water year precipitation and the ranked WY for the Bedell Flat HA ..

4. Map showing locations of the Bedell Flat monitoring wells where the prior infiltration test was conducted, the new Truckee Meadows Water Authority test well, the old Bureau of Land Management livestock well, and the Quaternary geologic map units and faults

5. Photographs showing seepage run measurement sites in the Bird Springs channel for Reach 1 inflow and outflow on March 7, 2017; Reach 2 inflow and outflow on March 14, 2017; and Reach 3 inflow and outflow on March 14, 2017

6. Map showing the measured and modeled seepage locations along the Bird Springs channel.

7. Image showing two-dimensional conceptual model used to derive seepage estimates from the Bird Springs channel using specified time variable head and temperature boundary conditions.

8. Graphs of simulated and observed sediment temperatures at Transect 1 for depths $0.10,0.20,0.50,0.75$ and 1.00 meter below land surface during the calibration period from February 3, 2017, at 4:00 a.m. to February 8, 2017, at 11:00 p.m

9. Graphs showing observed runoff stage and simulated seepage loss rates for Transect 1 and Transect 2 from February 3, 2017, to March 15, 2017...

10. Graphs showing observed stage and simulated seepage loss rates for Transect 3, Transect 4, , Transect 5, and Transect 6 from March 21, 2018, to March 24, 2018,.....21

11. Graphs showing simulated steady-state seepage loss rates for standardized stage conditions.

12. Graphs showing stage-discharge regressions estimated from Manning's equation for Transects 1-6.

13. Graphs showing physical characterization of the unsaturated zone from field measurements, bulk sediment samples, and core samples for soil water content, matric potential, sand, and clay at BF-MW-04 in the Bird Springs drainage; and SWC, matric potential, sand, and clay at BF-MW-07 in the Sand Hills drainage.

14. Graphs showing geochemical characterization from field characterization, bulk sediment samples, and core samples for electrical conductivity, pore-water nitrate as nitrogen, pore-water chloride, and molar ratios of chloride to nitrate at BF-MW-04 and BF-MW-07

15. Graphs showing compiled borehole lithologies corrected for elevation and the new conceptual recharge model for the Bird Springs and Sand Hills drainages 


\section{Tables}

1. Seepage-run site identifiers and locations used to estimate infiltration in Bird Springs channel

2. Domestic well summary for Bedell Flat ..................................................................9

3. Sediment descriptions from soil core sampling near temperature probes......................12

4. Summary of hydraulic and thermal parameters as input into the parameter-estimation model to calibrate the VS2DH transect models............................14

5. Measured seepage losses in March 2017.................................................................16

6. Model calibration root mean square difference for each temperature sensor at

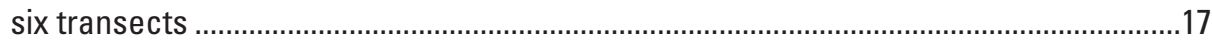

7. Optimized and default model parameters used for model simulations at each

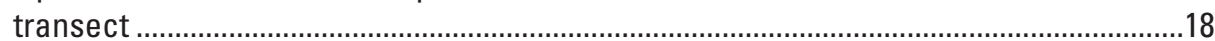

8. Estimated seepage losses along the Bird Springs channel for 4 cubic feet per second of imported water from Transects 1 to 6

9. Summary statistics for bulk sediment analyses for BF-MW-04 and BF-MW-07 ............26

10. Summary statistics of physical and geochemical properties between field measurements, bulk sediment samples, and core samples. 


\section{Conversion Factors}

U.S. customary units to International System of Units

\begin{tabular}{|c|c|c|}
\hline Multiply & By & To obtain \\
\hline \multicolumn{3}{|c|}{ Length } \\
\hline inch (in) & 2.54 & centimeter $(\mathrm{cm})$ \\
\hline inch (in) & 25.4 & millimeter $(\mathrm{mm})$ \\
\hline foot $(\mathrm{ft})$ & 0.3048 & meter $(\mathrm{m})$ \\
\hline mile (mi) & 1.609 & kilometer $(\mathrm{km})$ \\
\hline \multicolumn{3}{|r|}{ Area } \\
\hline acre & 0.4047 & hectare (ha) \\
\hline acre & 0.004047 & square kilometer $\left(\mathrm{km}^{2}\right)$ \\
\hline square mile $\left(\mathrm{mi}^{2}\right)$ & 2.590 & square kilometer $\left(\mathrm{km}^{2}\right)$ \\
\hline \multicolumn{3}{|c|}{ Volume } \\
\hline gallon (gal) & 3.785 & liter $(\mathrm{L})$ \\
\hline million gallons (Mgal) & 3,785 & cubic meter $\left(\mathrm{m}^{3}\right)$ \\
\hline cubic inch $\left(\mathrm{in}^{3}\right)$ & 16.39 & cubic centimeter $\left(\mathrm{cm}^{3}\right)$ \\
\hline cubic foot $\left(\mathrm{ft}^{3}\right)$ & 28.32 & cubic decimeter $\left(\mathrm{dm}^{3}\right)$ \\
\hline acre-foot (acre-ft) & 1,233 & cubic meter $\left(\mathrm{m}^{3}\right)$ \\
\hline \multicolumn{3}{|c|}{ Flow rate } \\
\hline foot per second (ft/s) & 0.3048 & meter per second $(\mathrm{m} / \mathrm{s})$ \\
\hline foot per hour (ft/h) & 0.3048 & meter per hour $(\mathrm{m} / \mathrm{h})$ \\
\hline cubic foot per second $\left(\mathrm{ft}^{3} / \mathrm{s}\right)$ & 0.02832 & cubic meter per second $\left(\mathrm{m}^{3} / \mathrm{s}\right)$ \\
\hline \multicolumn{3}{|r|}{ Mass } \\
\hline ounce, avoirdupois (oz) & 28.35 & gram $(\mathrm{g})$ \\
\hline pound, avoirdupois (lb) & 0.4536 & kilogram (kg) \\
\hline \multicolumn{3}{|c|}{ Density } \\
\hline pound per cubic foot $\left(\mathrm{lb} / \mathrm{ft}^{3}\right)$ & 0.01602 & gram per cubic centimeter $\left(\mathrm{g} / \mathrm{cm}^{3}\right)$ \\
\hline \multicolumn{3}{|c|}{ Energy } \\
\hline joule $(\mathrm{J})$ & 0.00095 & British thermal units (Btu) \\
\hline joule (J) & 0.2388 & calorie (cal) \\
\hline watt per square meter $\left(\mathrm{W} / \mathrm{m}^{2}\right)$ & 0.00142 & calorie per square centimeter per minute $\left(\mathrm{cal} / \mathrm{cm}^{2} \cdot \mathrm{min}\right)$ \\
\hline watt per square meter $\left(\mathrm{W} / \mathrm{m}^{2}\right)$ & 0.00529 & $\begin{array}{l}\text { British thermal unit per square foot per minute } \\
\left(\mathrm{Btu} / \mathrm{ft}^{2} \cdot \mathrm{min}\right)\end{array}$ \\
\hline kilowatthour (kWh) & $3,600,000$ & joule $(\mathrm{J})$ \\
\hline \multicolumn{3}{|c|}{ Hydraulic conductivity } \\
\hline foot per day $(\mathrm{ft} / \mathrm{d})$ & 0.3048 & meter per day $(\mathrm{m} / \mathrm{d})$ \\
\hline
\end{tabular}

Temperature in degrees Celsius $\left({ }^{\circ} \mathrm{C}\right)$ may be converted to degrees Fahrenheit $\left({ }^{\circ} \mathrm{F}\right)$ as follows:

$$
{ }^{\circ} \mathrm{F}=\left(1.8 \times{ }^{\circ} \mathrm{C}\right)+32 .
$$




\section{Datum}

Vertical coordinate information is referenced to North American Vertical Datum of 1988 (NAVD 88).

Horizontal coordinate information is referenced to the North American Datum of 1983 (NAD 83), and the World Geodetic System of 1984 (WGS 84) where noted.

Altitude, as used in this report, refers to distance above the vertical datum.

\section{Supplemental Information}

Specific conductance is given in deciSiemens per meter at 25 degrees Celsius ( $\mathrm{dS} / \mathrm{m}$ at $25^{\circ} \mathrm{C}$ ).

Concentrations of chemical constituents in water are given in milligrams per liter (mg/L). 


\section{Abbreviations}

\begin{tabular}{ll} 
ASR & Aquifer storage and recovery \\
bls & Below land surface \\
BLM & Bureau of Land Management \\
Cl & Chloride \\
EC & Electrical conductivity \\
ERS & Electrical resistance sensors \\
GPS & Global Position System \\
h & hour \\
HA & Hydrographic Area \\
KCI & Potassium chloride, standard reference solution \\
MAR & Managed aquifer recharge \\
MGD & Million gallons per day \\
MW & Monitoring well \\
$N$ & Number of samples or observations \\
NLCD & National Land Cover Database \\
NO ${ }_{3}$-N & Nitrate as nitrogen \\
$R$ & Pearson rank correlation coefficient \\
$R^{2}$ & Coefficient of determination \\
PEST & Parameter-ESTimation software suite \\
$p$ & Statistical probability value \\
RIB & Rapid infiltration basin \\
RMSD & Root-mean square difference \\
RPD & Relative percent difference \\
SO ${ }_{4}-\mathrm{S}$ & Sulfate as sulfur \\
SWC & Soil water content \\
TMWA & Truckee Meadows Water Authority \\
TROD & Temperature rod \\
USGS & U.S. Geological Survey \\
WY & Water Year (October-September) \\
\hline
\end{tabular}




\title{
Surface Infiltration and Unsaturated Zone Characterization in Support of Managed Aquifer Recharge in Bedell Flat, Washoe County, Nevada
}

\author{
By Todd Caldwell', Ramon Naranjo ${ }^{1}$, David Smith ${ }^{1}$, and Christian Kropf ${ }^{2}$
}

\section{Abstract}

Aquifer storage and recovery (ASR) expands the portfolio of public water supply and improves resiliency to drought and future water demand. This study investigated the feasibility of ASR in the Bedell Flat Hydrographic Area using land-based methods including in-channel managed aquifer recharge (MAR) and rapid infiltration basins (RIB). Bedell Flat, one of two flow-through groundwater basins near Reno, Nevada, was a likely candidate for ASR because of its deep basin fill, proximity to supplemental water sources and infrastructure, and lack of development. In-channel MAR feasibility was determined from seepage losses along the Bird Springs ephemeral channel measured using Parshall flumes and heat-as-a-tracer inverse modeling. The feasibility of RIB was evaluated by characterizing vadose zone boreholes installed with roto-sonic drilling to water table. Field characterization of sediment and lithologic descriptions was accomplished at 1-foot (ft) increments. Bulk sediment samples were collected every $5 \mathrm{ft}$ and cores from a split spoon were sampled at 10, 20, 30, 40, 60 and $100 \mathrm{ft}$ below land surface (bls). Collected samples were analyzed for texture, moisture content, and geochemistry.

Infiltration rates in Bird Springs channel increased downgradient with the hydraulic conductivity of the upper reaches ranging from 0.002 to 0.14 meter per hour $(\mathrm{m} / \mathrm{h})$

${ }^{1}$ USGS Nevada Water Science Center

${ }^{2}$ Truckee Meadows Water Authority and the lower reaches from 0.5 to $1.5 \mathrm{~m} / \mathrm{h}$. Differences in discharge measurements indicate that seepage losses also increase down channel. When normalized to $1 \mathrm{ft}$ of channel stage, modeled seepage loss rates ranged from 0.02 to 5.34 cubic feet per second ( $\left.\mathrm{ft}^{3} / \mathrm{s}\right)$ per mile (mi). Perched zones of soil moisture residing on top of dry fine-textured, clay-rich layers were prevalent in the Bird Springs drainage, indicating complicated flow paths for any supplement recharge water. Characterization of boreholes in Bird Springs drainage indicates low permeability clay layers $1-10 \mathrm{ft}$ thick interbedded within extensive, grussy sands of high permeability. The presence of low permeability clay layers (1-10 ft thick) prompted a shift in analysis to the adjacent Sand Hills drainage where four additional boreholes indicated fewer perched water zones and at greater depths. Nitrates in the sediment pore-water (a condition that would discourage ASR) were integrated with depth to the aquifer $180 \mathrm{ft}$ bls. Wells BF-MW-04 (Bird Springs) and BF-MW-07 (Sand Hills) contained 4,270 and 2,436 kilograms per hectare of nitrogen, respectively, which could potentially load excessive nitrogen to a receiving aquifer.

An economically viable ASR project requires a minimum input of 2 million gallons per day (approximately $3 \mathrm{ft}^{3} / \mathrm{s}$ ), which either channel appears to have the sufficient capacity to infiltrate such a volume before reaching the valley bottom of Bedell Flat. However, the trajectory of the infiltrated water is complicated by the lithology and lateral transmissivity of the underlying sediments. There is also concern that this volume of infiltrated water may cause undesirable groundwater levels at the outflow in less than 5 years. 


\section{Introduction}

As population centers grow in arid western United States, public water providers are looking to broaden options available for effective management of limited water resources. Because drought frequency and duration are increasing, water management requires resiliency that may be achieved or enhanced through aquifer storage and recovery (ASR; Fetter and Holzmacher, 1974; Bouwer, 2002; Sheng, 2005). Surface water can be stored in suitable aquifers and recovered for public supply during times of need because the timing of excess waters from spring snowmelt does not necessarily coincide with water demand. Wastewater is a consistent water resource for ASR but requires substantial treatment before subsurface injection; however, surface applications can improve water quality through soil-aquifer treatment as recharge water percolates through the unsaturated zone. This project provided technical assistance to Truckee Meadows Water Authority (TMWA) to evaluate the feasibility for a successful ASR program in the Bedell Flat Hydrographic Area in northern Nevada, ideally using advanced purified water (that is, reused water treated to drinking water standards by filtration, reverse osmosis, and disinfection) from more populated, adjacent closed basins.

The feasibility of managed aquifer recharge (MAR; Dillon and others, 2019) using in-channel (Standen and others, 2020), rapid infiltration basins (RIB; Andres and Sims, 2013), or subsurface injection depends on the hydrogeologic characteristics of the aquifer and overlying vadose zone (Bouwer, 2002). Recharging advanced purified water through the unsaturated zone (that is, soil-aquifer treatment) reduces unwanted constituents while also encouraging microbial reduction of contaminants (Bouwer and Rice, 1984; Dillon, 2005; Sharma and Kennedy, 2017). The goal of ASR is to provide a resilient water supply and improve water-system sustainability to adapt to the changing climate and increasing demand. However, feasibility depends on scientific and economic considerations, also known to cooperators as "Deal Breakers." In feasibility studies, deal breakers for ASR present themselves along various pathways to project implementation, including (1) environmental or regulatory issues,

(2) permitting or access issues, (3) availability of water and required infrastructure to artificially recharged groundwater, (4) the capacity of the unsaturated zone to receive and store recharged water, (5) sufficient aquifer storage capacity, (6) flooding hazard at the ASR facility, (7) compatible water chemistry between infiltrating water and groundwater, and

(8) sufficient recovery potential.

Furthermore, ASR efficiency can be affected by degradation of aquifer properties caused by biosolids and chemical reactions between recharged and native groundwaters/aquifer materials, which can clog pores and reduce infiltration and groundwater recovery capacity. Other common water-quality concerns with ASR projects are that introduced water may lead to elevated concentrations of dissolved solids in the native groundwater and mobilize naturally occurring constituents such as nitrate, arsenic, and perchlorate from unsaturated sediments. Lastly, there are logistical considerations related to site access, infrastructure protection, and local permitting.

Bedell Flat in Washoe County, Nevada (fig. 1), was a top candidate for a large-scale ASR project by the TMWA. The populated basins to the south (that is, Cold Springs, Lemmon Valley West, and Lemmon Valley East) have water treatment facilities on playas located on the basin floor at Swan and Silver Lakes (fig. 1); both of which filled with excessive runoff from the combination of an exceptional water year (WY) 2017 and changes to impervious cover and land-use, flooding the treatment facilities. The effluent remaining in these playas, which has no escape but through evaporation, could serve as a supplemental water source for ASR to proximal basins like Bedell Flat. Preliminary assessments of Bedell Flat were encouraging. The area was undeveloped, consisting almost entirely of public land managed by the Bureau of Land Management (BLM), and it was not hydrologically closed. Available groundwater-quality data indicated good quality water suitable for drinking without additional treatment, and the presence of a nearby water infrastructure in the valley that could eventually export recovered water (Fish Springs Pipeline in fig. 2). The Bird Springs channel is well defined for 10 kilometers through the upper drainage (southeast) before it loses definition over the thick basin deposits in the Bedell Flat valley bottom. Groundwater flow parallels in the Bird Springs channel to the northeast then turns northwest into thinning alluvial deposits, ultimately discharging to a seep at Tod Hunter Spring. Berger and others (2001) found no presence or evidence of fine-grained materials such as lacustrine or playa deposits, and available water-level data indicated a thick unsaturated zone up to 200 feet (ft).

This study focused on the feasibility of ASR in the Bedell Flat by quantifying natural seepage losses along the Bird Springs ephemeral channel (table 1) for in-channel MAR and characterizing the unsaturated zone (Smith and others, 2021) for the implementation of RIB galleries. This report was prepared in cooperation with the TMWA, the public authority providing regional water supply for the greater Reno-Sparks metropolitan area. The TMWA has identified the need to implement long-term, sustainable water management practices including several ASR options within the North Valleys, and in particular, the Bedell Flat (fig. 1). The North Valleys are a geographical term for the 9 closed hydrologic basins located $30 \mathrm{~km}$ north of Reno, Nev., and serviced by TMWA. These options would include infiltration of advanced purified water either along a natural ephemeral channel (that is, in-channel MAR) or in an engineered RIB gallery, along with direct injection of imported potable water. A thorough understanding of site hydrologic, hydrogeologic, and geochemical characteristics was needed to determine the potential success of a long-term ASR program before making the substantial capital investments necessary to import advanced purified water from more populated North Valleys of the Reno metropolitan area. 
$120^{\circ}$

45

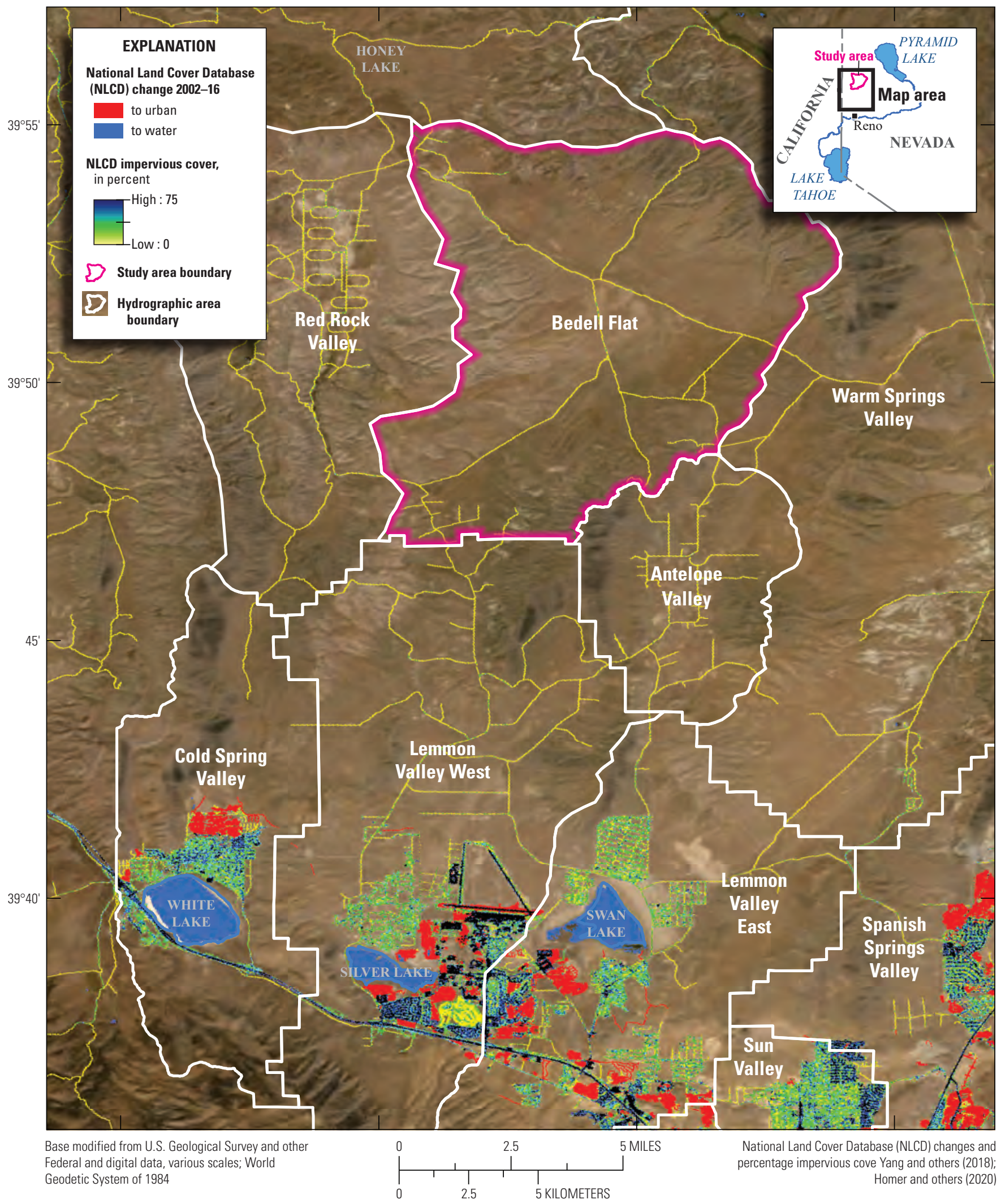

Figure 1. The Bedell Flat hydrographic area in Washoe County, 30 kilometers north of Reno, Nevada. 


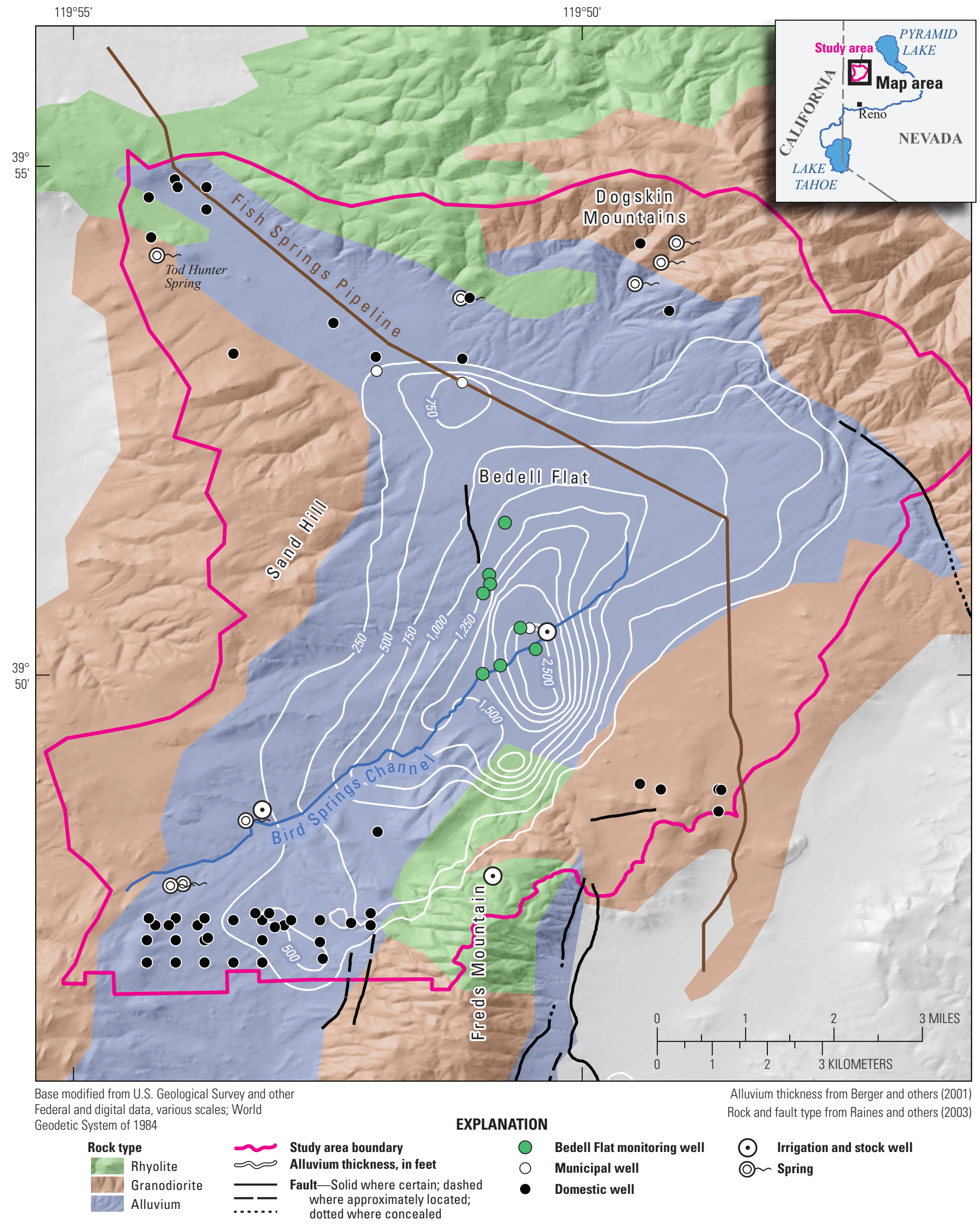

Figure 2. Bedrock geology of the Bedell Flat hydrographic area and lines of equal combined thickness of basin-fill deposits and volcanic rocks, in feet. 
Table 1. Seepage-run site identifiers and locations used to estimate infiltration in Bird Springs channel.

[NAD 83, North American Datum of 1983; NAVD 88, North American Vertical Datum of 1988]

\begin{tabular}{clccc}
\hline \multicolumn{1}{c}{ Site number } & \multicolumn{1}{c}{ Site name } & $\begin{array}{c}\text { Latitude } \\
\text { (NAD 83) }\end{array}$ & $\begin{array}{c}\text { Longitude } \\
\text { (NAD 83) }\end{array}$ & $\begin{array}{c}\text { Elevation } \\
\text { (NAVD 88) }\end{array}$ \\
\hline 394812119533101 & BIRD SPRINGS DRAINAGE REACH 1 INFLOW & 39.803 & -119.892 & $5,489.0$ \\
394815119532601 & BIRD SPRINGS DRAINAGE REACH 1 OUTFLOW & 39.804 & -119.891 & $5,472.1$ \\
394857119522301 & BIRD SPRINGS DRAINAGE REACH 2 INFLOW & 39.816 & -119.873 & $5,324.3$ \\
394908119520501 & BIRD SPRINGS DRAINAGE REACH 2 OUTFLOW & 39.819 & -119.868 & $5,286.9$ \\
394909119520401 & BIRD SPRINGS DRAINAGE REACH 3 INFLOW & 39.819 & -119.868 & $5,284.4$ \\
394914119515001 & BIRD SPRINGS DRAINAGE REACH 3 OUTFLOW & 39.821 & -119.864 & $5,269.0$ \\
\hline
\end{tabular}

The original feasibility objective was to be completed using a combination of methods including infiltration experiments, seepage-loss estimates, borehole characterization, surface and borehole geophysics, along with numerical simulations to simulate the capacity of the alluvium to accept water. Seepage measurements using in-stream monitoring and differential gaging (the difference in measured discharge at two stations) began in 2017 and 2018, while 2019 did not generate any runoff events. Borehole characterization was completed in 2019. Following this phase, TMWA conducted an aquifer test and found the primary aquifer was semi-confined and infeasible for ASR (Kropf and others, 2020).

\section{Purpose and Scope}

The purpose of this report is to provide TMWA information on natural channel and vadose zone infiltration to determine the feasibility for ASR using in-channel MAR or a RIB gallery within Bedell Flat in Washoe County, Nevada. Water imported to Bedell Flat for ASR would either be discharged to the Bird Springs channel and allowed to naturally infiltrate, delivered to the RIB gallery for concentrated surface infiltration, or directly injected into the aquifer. One of several feasibility targets is importing 2 million gallons per day (MGD; $4 \mathrm{ft}^{3} / \mathrm{s}$ ), which would ideally fully infiltrate before imported surface water reached the valley floor. The scope of this report is to quantify seepage loss rates along the Bird Springs ephemeral channel and characterize the unsaturated zone using borehole data within the Bird Springs and Sand Hills drainages (fig. 2). The goal of the unsaturated zone characterization was to update the long-accepted conceptual model of groundwater recharge to the underlying aquifer and determine the potential trajectory of MAR water through the vadose zone (Nawikas and others, 2016).

\section{Bedell Flat Hydrographic Area Description}

The hydrographic areas (HA) in the North Valleys of Reno, Nevada, are structurally closed, hydrologic basins that drain to ephemeral playa lakes including White, Silver, and Swan Lakes (fig. 1). Spring snowmelt runoff entering these terminal lakes can only leave through evapotranspiration or groundwater pumping. North-south trending extensional faults differentiate each HA between uplands of Cenozoic-Mesozoic rock and valleys of thick basin fill of Quaternary alluvium. Bedell Flat is an elongated, northeast trending depression with alluvial deposits extending nearly $2,500 \mathrm{ft}$ below land surface (bls; Berger and others, 2001). The Bedell Flat HA is 51 square miles and bounded to the north and east by Dogskin Mountain, to the south by Freds Mountain, and the west by Sand Hill (fig. 2).

\section{Landcover and Climate}

Population growth in the Reno-Sparks metropolitan area has pushed urban expansion into the once rural North Valleys. In particular, Cold Spring Valley and Lemmon Valley West have seen a considerable increase in the percentage of impervious area and conversion to urban cover (fig. 1), according to the National Land Cover Database (Yang and others, 2018; Homer and others, 2020). Such growth has been particularly dense around the ephemeral playas to the south, which are typically dry. The average annual water year (WY, the period from October 1 through September 30 named for the year in which the period ends) precipitation during 1980-2020 was 11.7 inches (in.; 296 millimeters ; Abatzoglou, 2013; Moffet and others, 2019) with the majority falling as snow between November and March (fig. 3C). Daily mean air temperature in the valley is 47.8 degrees Fahrenheit $\left({ }^{\circ} \mathrm{F}\right.$; 8.8 degrees Celsius, ${ }^{\circ} \mathrm{C}$ ) reaching a maximum of $71.6^{\circ} \mathrm{F}$ $\left(22^{\circ} \mathrm{C}\right)$ in July and minimum of $33.1^{\circ} \mathrm{F}\left(0.6^{\circ} \mathrm{C}\right)$ in December. 

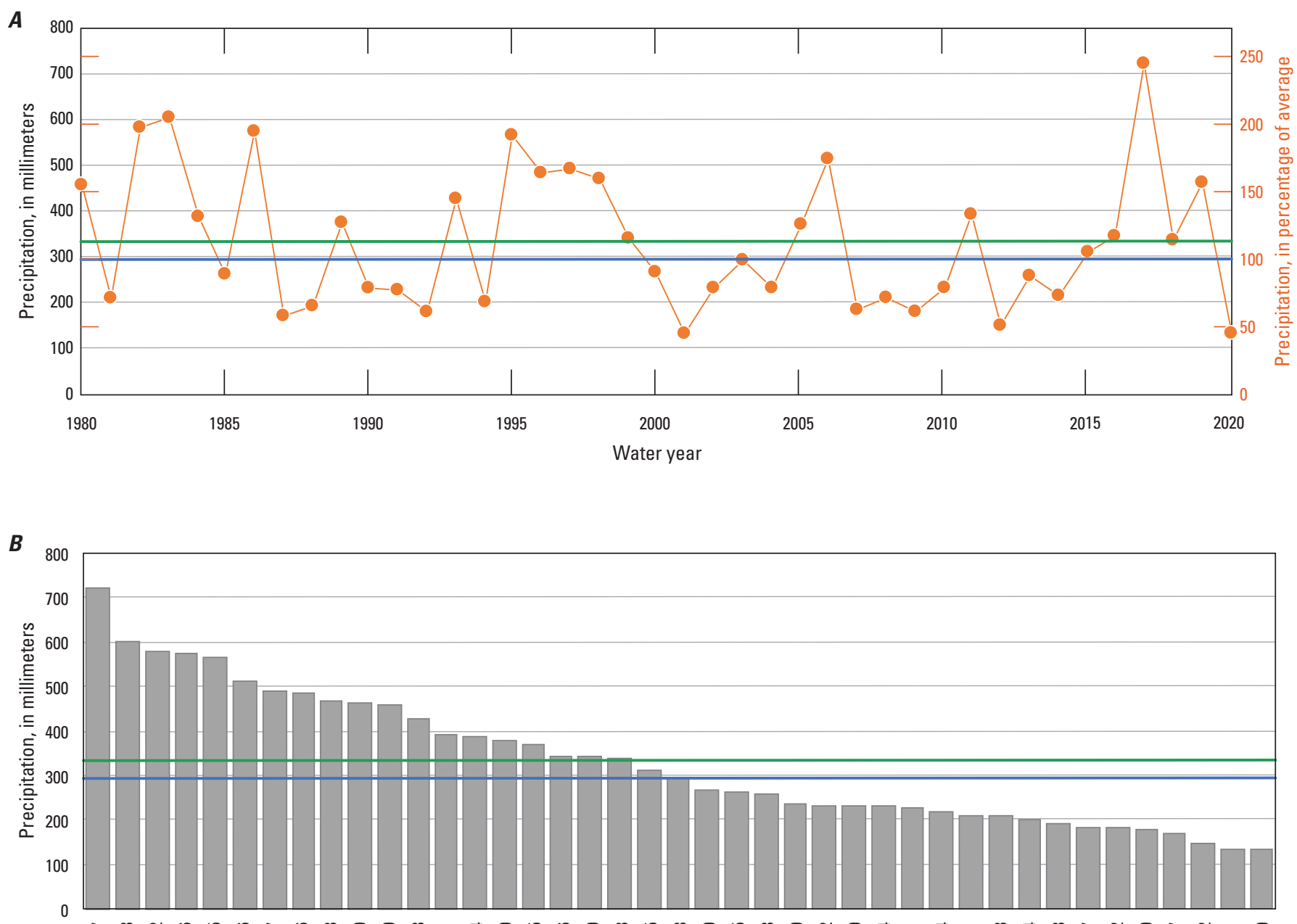

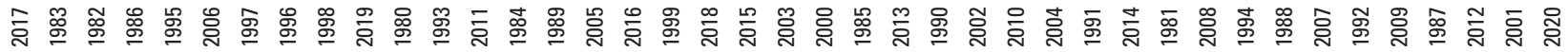

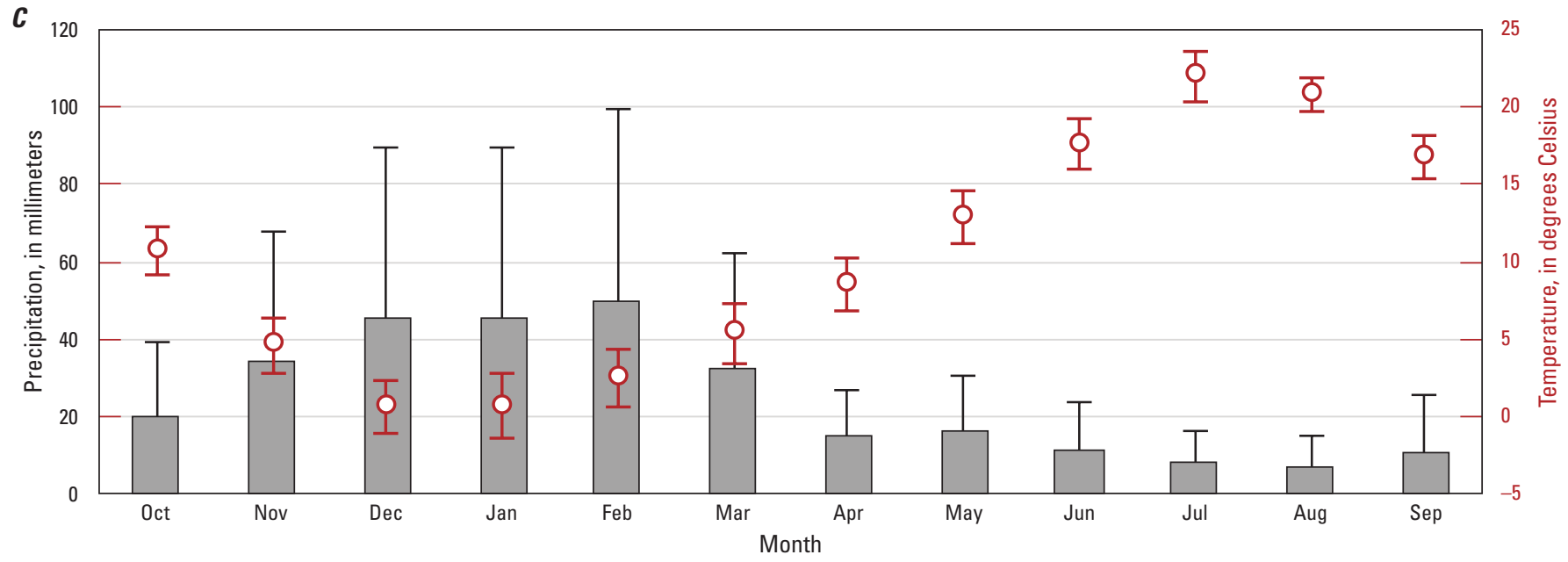

Figure 3. $A$, Interannual variability in water year (WY) precipitation and $B$, ranked WY for the Bedell Flat HA. The 40-year annual average and median are shown by the green and blue horizontal lines, respectively. $C$, The monthly mean and standard deviation (error bars) climatology for precipitation (bars) and air temperature (circles). Obtained from Moffet and others (2019). 


\section{Geology}

The North Valleys lie at the westernmost extent of the Great Basin Desert and the Basin and Range Province. The mountain ranges are generally parallel, linear features that rise steeply between wide valleys of broad alluvial plains and axial washes ultimately terminating in playas. The crests of these mountains are extrusive volcanic rock or sedimentary limestones that overtop intrusive igneous Cenozoic and Mesozoic rocks. Extensional tectonic forces created broad intermontane structural basins that filled with alluvium. The closed hydrologic basins produce pans, flats, depressions, and deflation basins along with relict Pleistocene features related to long-lived lake stands during wetter, pluvial periods (Peterson, 1981).

Bedell Flat has a similar structural framework with granodiorite mountains offset by northwest trending normal faults (fig. 2) according to Raines and others (2003). Freds Mountain and the north side of Dogskin Mountain are capped with 24-million-year-old Cenozoic rhyolitic rocks, whereas the thick basin deposits are primarily alluvium (Henry and others, 2009). Key Quaternary units and exposed bedrock along Bird Springs drainage, from young to old, include (Garside, 1993):

- Qa: Active alluvium consisting of cobble-pebble gravels and sands typically 1.6-10-ft thick along defined drainage channels.

- Qf: Undifferentiated and undissected alluvial fan deposits that may exceed a thickness of $65 \mathrm{ft}$.

- Qof: Older alluvial fan deposits with arkosic clastic material from granitic rocks.

- Qopg: Highly dissected, older pediment deposits consisting of muddy (clay-rich) sands.

- Ts: Tertiary sedimentary rocks including lacustrine and fluvial conglomerate, sandstone, and tuffaceous siltstones.

- Mzqm: Quartz monzonite, possibly a Cretaceous intrusion into granodiorite rocks (Mzgd).

- Mzgd: Granodiorite, resistant to weathering, forming blocky to spheroidal corestone surrounded by grus (that is, decomposed granite).

The valley floor of Bedell Flat is $4,800 \mathrm{ft}$ above sea level. Pluvial Lake Lahontan reached its highest elevation of 4,391 ft about 13,000 years ago, covering much of the floor of the Great Basin with fine-grained lake deposits (Adams and Wesnousky, 1998). Unlike the closed basins in the North Valleys, Bedell Flat drains north toward Honey Lake and lacks any shoreline features, beach ridges, or Quaternary lacustrine deposits as it was likely well above the historical highstand of Lake Lahontan (Berger and others, 2001). Such deposits tend to be laterally extensive, thick and fine grained, and unlikely to support surface infiltration or RIB operations. Thus, Bedell Flat HA was an attractive flow-through basin for MAR.

Recently, Henry and others (2009) revisited the area as part of an investigation of the northern Walker Lane fault system, a northwest-trending belt of active, right-lateral strike-slip faults, which they mapped running through the valley floor of Bedell Flat, accommodating 6-8 $\mathrm{mm}$ per year of movement; they also mapped the Freds Mountain faults shown in figure 4 (Garside, 1993). Henry and others (2009) showed the Freds Mountain normal faults offsetting older Mesozoic granitic and metamorphic rocks (for example, Mzqm and Mzgd) on the west side with younger Miocene-Pliocene sedimentary rocks (for example, Ts) on the east side. The sandstone parent rocks of the Sand Hills drainage (fig. 4) produce coarse sands and little clay, whereas Bird Springs drainage is more complex. The source rock in Bird Springs drainage is primarily grussy granodiorite, and the drainage is incised into the muddy material of Qopg, which makes Bird Springs Road nearly impassable even after light rains. Furthermore, Henry and others (2009) indicated that the entire North Valleys may have been a continuous extension of the Honey Lake Basin before active faulting in the Quaternary, after which ponded deposition of fines were likely to occur locally.

\section{Hydrogeology}

The Bedell Flat and other North Valley HAs were originally studied for their water resource potential by Rush and Glancy (1967). They estimated the annual water balance of Bedell Flat by assuming inputs of 1,100 acre-feet (acre-ft) of natural inflow from Antelope Valley and 28,000 acre-ft of direct precipitation with approximately 4 percent of the input becoming groundwater recharge (1,100 acre-ft). Water losses included 30 acre-ft consumed by groundwater evapotranspiration and interbasin groundwater flow west into Red Rock Valley at approximately 250 acre-ft. Annual surface water discharge was estimated at 70 acre-ft. They noted an imbalance of 900 acre-ft is likely because of an overestimate of recharge (Rush and Glancy, 1967). There is currently no noticeable surface water in Bedell Flat, even following WY 2017-the wettest year on record. Perennial springs are located throughout the margins of Bedell Flat generally at or near the contact between consolidated bedrock and alluvium. For example, basin fill pinches out to the northwest resulting in groundwater discharge as a seep at Tod Hunter Spring (fig. 2), but the majority of outflow from Bedell Flat is likely underflow to adjacent valleys (Rush and Glancy, 1967). 


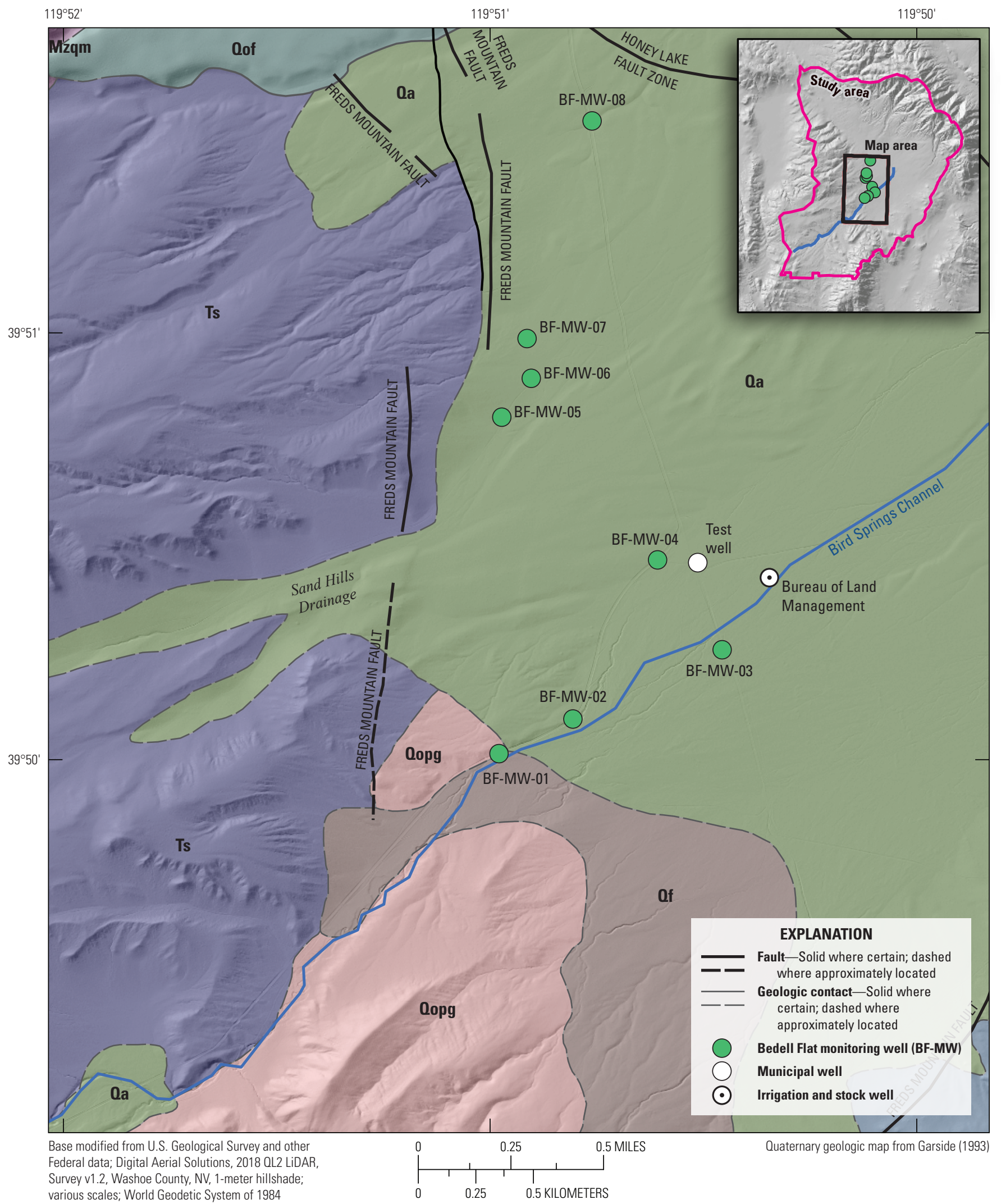

Figure 4. The locations of the Bedell Flat monitoring wells (BF-MW) where the prior infiltration test was conducted (GeoSystems Analysis, 2019), the new Truckee Meadows Water Authority (TMWA) test well, the old Bureau of Land Management (BLM) livestock well, and the Quaternary geologic map units and faults (Garside, 1993). 
Berger and others (2001) noted five hydrogeologic units in Bedell Flat including (1) Jurassic/Triassic metamorphic rocks, (2) Mzgd, (3) Tertiary volcanics, (4) older Quaternary alluvium (Qof), and (5) younger Quaternary alluvium (Qa). The pre-Cenozoic basement (units 1 and 2) are fractured and may have locally high transmissivity but are not very productive. Cenozoic basin fill (units $3-5$ ) is thick (approximately 2,500 ft) in the central basin (fig. 2), but only the younger alluvium (less than $300 \mathrm{ft}$ ) is an important water-bearing formation (Berger and others, 2001).

\section{Existing Well Logs}

A query of well logs (http://water.nv.gov/ welllogquery.aspx, accessed August 1, 2019) from the State of Nevada Division of Water Resources for Bedell Flat (Basin 094) produced 71 domestic wells, 3 irrigation wells, and 2 municipal wells. As shown in figure 2, domestic wells are sparse and primarily in the south and northwest portions of the Bedell Flat HA. Beginning in 1978, domestic wells were typically drilled to 300 or $400 \mathrm{ft}$ reaching a maximum total depth of $945 \mathrm{ft}$ with a mean static water level of $175 \mathrm{ft}$ (table 2). Bedrock was only noted in 14 logs, ranging from 9 to $822 \mathrm{ft}$ bls. The first municipal well (permit number [no.] 26274) was installed in 1972 and later reestablished in 2007 in the northwest corner near the discharge point of the basin. Both well records indicated shallow static water depths (50-60 ft) and total well depths of 950 and $400 \mathrm{ft}$, respectively, but after minimal pumping time, both went dry. In general, urban expansion into Bedell Flat has likely been limited by federally controlled public lands and low aquifer yield, particularly around the rim of the basin.

Three irrigation stock wells were completed in the 1950s including the original BLM stock well in the center of the Bedell Flat. The original BLM well (well log no. 4830) was completed to $224 \mathrm{ft}$ with a static water level of $207 \mathrm{ft}$. In 2018, TMWA completed a new BLM stock well to a depth of $405 \mathrm{ft}$ with a static water level of $181 \mathrm{ft}$ (well log no. 129394). The new BLM Test Well is $800 \mathrm{ft}$ from the original stock well, which is still in use for existing grazing permits, whereas the

Table 2. Domestic well summary for the Bedell Flat Hydrographic Area, Washoe County, Nevada.

[fbls, feet below land surface]

\begin{tabular}{cccccc}
\hline Category & Mean & Median & Maximum & Minimum & Number \\
\hline $\begin{array}{c}\text { Static water } \\
\text { level, in fbls }\end{array}$ & 175 & 79 & 690 & 5 & 66 \\
$\begin{array}{c}\text { Bedrock depth, } \\
\quad \text { in fbls }\end{array}$ & 220 & 209 & 822 & 9 & 14 \\
$\begin{array}{c}\text { Total well } \\
\text { depth, in fbls }\end{array}$ & 383 & 300 & 945 & 120 & 71 \\
\hline
\end{tabular}

new TMWA test well (fig. 4) is large enough (6-in. diameter) and screened from 200 to $400 \mathrm{ft}$ to accommodate a pump sufficient for aquifer testing.

\section{Aquifer Testing and Groundwater Modeling by the Truckee Meadows Water Authority}

In 2019, eight monitoring wells (BF-MW-01 through -08) were installed in the Bedell Flat (fig. 4), five of which reached the saturated zone (BF-MW-02, -03, -04, -07, and -08). In December 2019, TMWA conducted a multi-well aquifer test using the new Test Well for pumping at 415 gallons per minute with instrumentation in five nearby wells (including shallow and deep well pairs at BF-MW-04 and BF-MW-07; fig. 4). Water-level drawdown was observed within 10 minutes and rapidly increased to $5 \mathrm{ft}$ during the course of the 45 -h test at BF-MW-04, $440 \mathrm{ft}$ from the pumping well. Monitoring well BF-MW-07, which is 3,700 ft from the pumping well, showed a response to pumping after 200 minutes and a total drawdown of $0.1 \mathrm{ft}$. These data (Kropf and others, 2020) were used by TMWA to estimate hydraulic conductivity and storativity values of $30 \mathrm{ft} /$ day and 0.001 , respectively. The combination of rapid response to pumping in distal wells and low storativity led TMWA to designate the aquifer as semi-confined to confined (Kropf and others, 2020).

A three-dimensional groundwater flow model (MODFLOW-NWT) was constructed by TMWA (Kropf and others, 2020) to simulate aquifer response to recharge activities of $2 \mathrm{MGD}$ - the feasibility target for ASR in Bedell Flat. Under confined aquifer conditions, their results indicated that artificial recharge could potentially create rapid transmission of hydraulic pressure responses throughout large portions of Bedell Flat and could cause undesirable shallow groundwater conditions at the groundwater discharge area (Tod Hunter Spring) at the north end of the valley. Kropf and others (2020) concluded that TMWA would need at least 10 years of storage before recovery operations would begin and that volume of water exceeded the estimated aquifer capacity and was therefore a "deal breaker" for ASR facility in Bedell Flat.

\section{Methods of Investigation}

This section describes the methods used to estimate seepage rates along the ephemeral Bird Springs channel and the methods used to characterize properties of sediments in Bedell Flat. Seepage measurements and borehole characterization data are available as a U.S. Geological Survey (USGS) data release at https://doi.org/10.3133/sir20215137 (Smith and others, 2021). Input and output files for the VS2DH numerical model are available as a USGS data release at https://doi.org/10.3133/sir20215137 (Naranjo and others, 2021). 


\section{Seepage Loss Estimates}

Seepage along the Bird Springs channel was estimated by monitoring runoff events using direct (fig. 5) and indirect methods during runoff in the WY 2017 and 2018. No measurements were made in 2019 due to lack of runoff. The direct methods involve seepage runs, where flow was measured and differenced at inflow and outflow locations between reaches (fig. 6). Indirect methods involve monitoring thermal gradients and stage at six transects then using inverse modeling and heat-as-a-tracer methods (Constantz, 2008). Hydraulic and thermal soil properties were optimized using measured and simulated temperatures in the objective function for inverse model calibration (Naranjo and others, 2021).
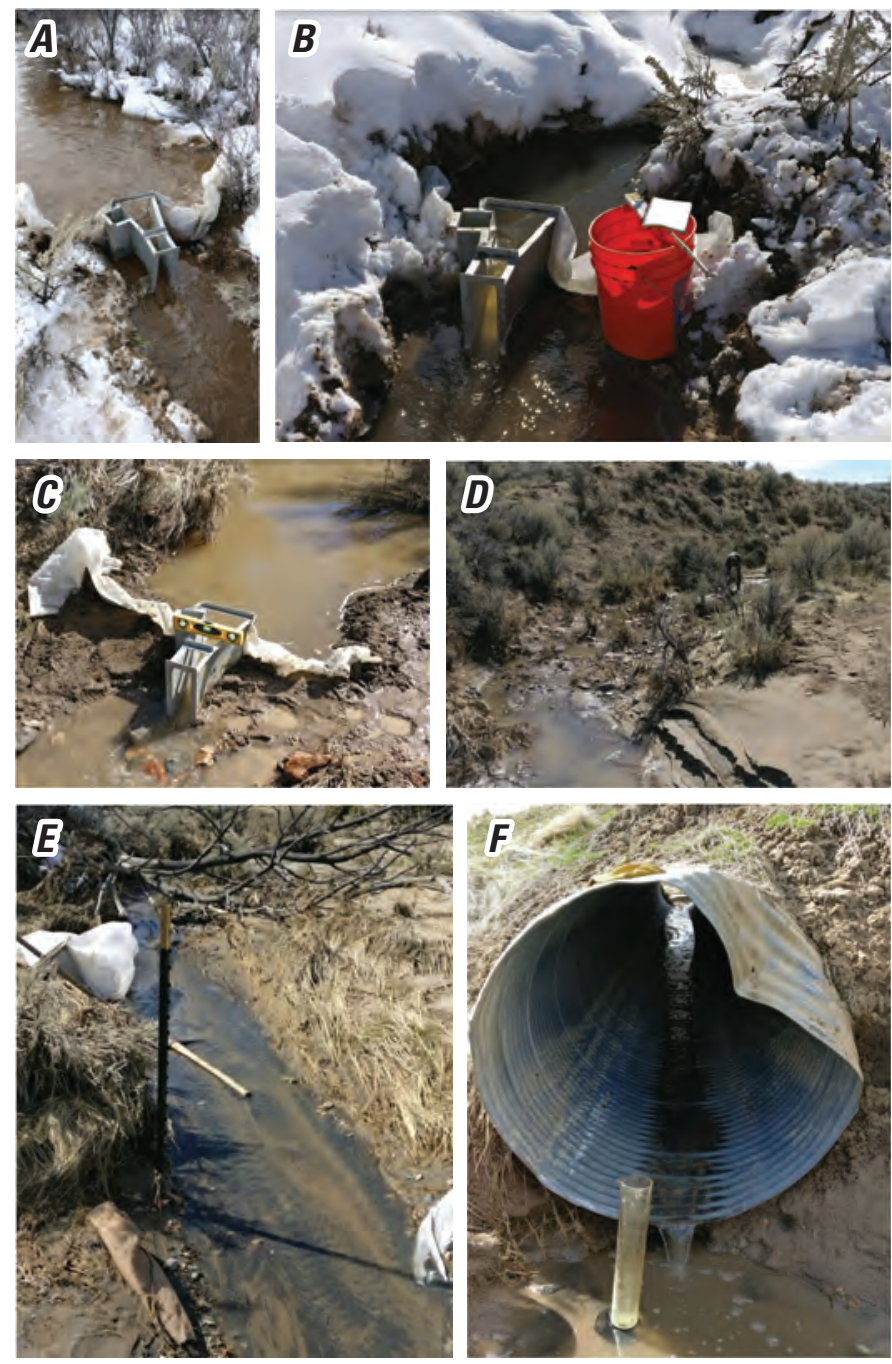

Figure 5. Seepage run sites in the Bird Springs channel for the Reach $1 A$, inflow and $B$, outflow on March 7, 2017; Reach 2 $C$, inflow and $D$, outflow on March 14, 2017; and Reach $3 E$, inflow and $F$, outflow on March 17, 2017. Photographs by David Smith, U.S. Geological Survey.
Calibrated models were then used to estimate reach loss rates over a range of prescribed stage conditions to develop stage-loss regressions. Herein, we define "reach losses" as measured losses over a known length of channel as determined from inflow minus outflow discharge measurements between flumes (Smith and others, 2021) and "transect losses" as model-based estimates from continuous measurements of head and sediment temperatures (Naranjo and others, 2021; fig. 6).

\section{Seepage Run Measurements}

Seepage runs were used to measure flow losses between specific reaches of the Bird Springs channel (fig. 6). Discharge was measured by two, 3-in-modified Parshall flumes between three reaches of the Bird Springs channel installed in advance of anticipated flow events (table 1; fig. 5). Flow measurements were limited to less than $1 \mathrm{ft}^{3} / \mathrm{s}$ because of the size of the flumes used. Episodic flow events were primarily driven by rain on snow, which required the use of a combination of methods to confirm the presence and duration of runoff. During sustained flow events in 2017, flumes were used to measure discharge at three reaches in the Bird Springs channel. A seepage run reach is identified as the length of channel between the inflow and outflow flume locations. Discharge measurements at the inflow and outflow flumes were simultaneously collected during a 15-minute period using methods outlined by Turnipseed and Sauer (2010). Seepage loss rate along each reach was calculated by dividing the flow lost between the respective inflow and outflow discharge measurements by the respective reach lengths (Rosenberry and LaBaugh, 2008).

\section{Flow Stage and Duration}

Stage and duration of flow at each transect in Bird Spring channel was monitored using pressure transducers supplemented with time-lapse cameras and electrical resistance sensors (ERS). Time-lapse cameras and ERS were used to verify the presence of surface-water flow, duration, and wetted area during runoff events (Smith and others, 2021). Multiple approaches were necessary given that the pre-flow conditions usually consisted of snow accumulation and ice around the sensors. Also, during no-flow conditions, snow accumulation and atmospheric barometric fluctuations add noise to pressure transducer data, making it difficult to determine the precise time when flow initiated. Pressure transducers attached to T-posts were positioned 5 centimeters $(\mathrm{cm})$ above the channel sediments and could potentially miss the onset of flow if the stage was not high enough to submerge the sensor (fig. 5E). Therefore, ERS and time-lapse cameras were also deployed at each transect. Electrical resistance sensors were made by modifying Onset Hobo Pendant waterproof light and temperature loggers (Model UA-002-64) based on methods described by Chapin and others (2014). 


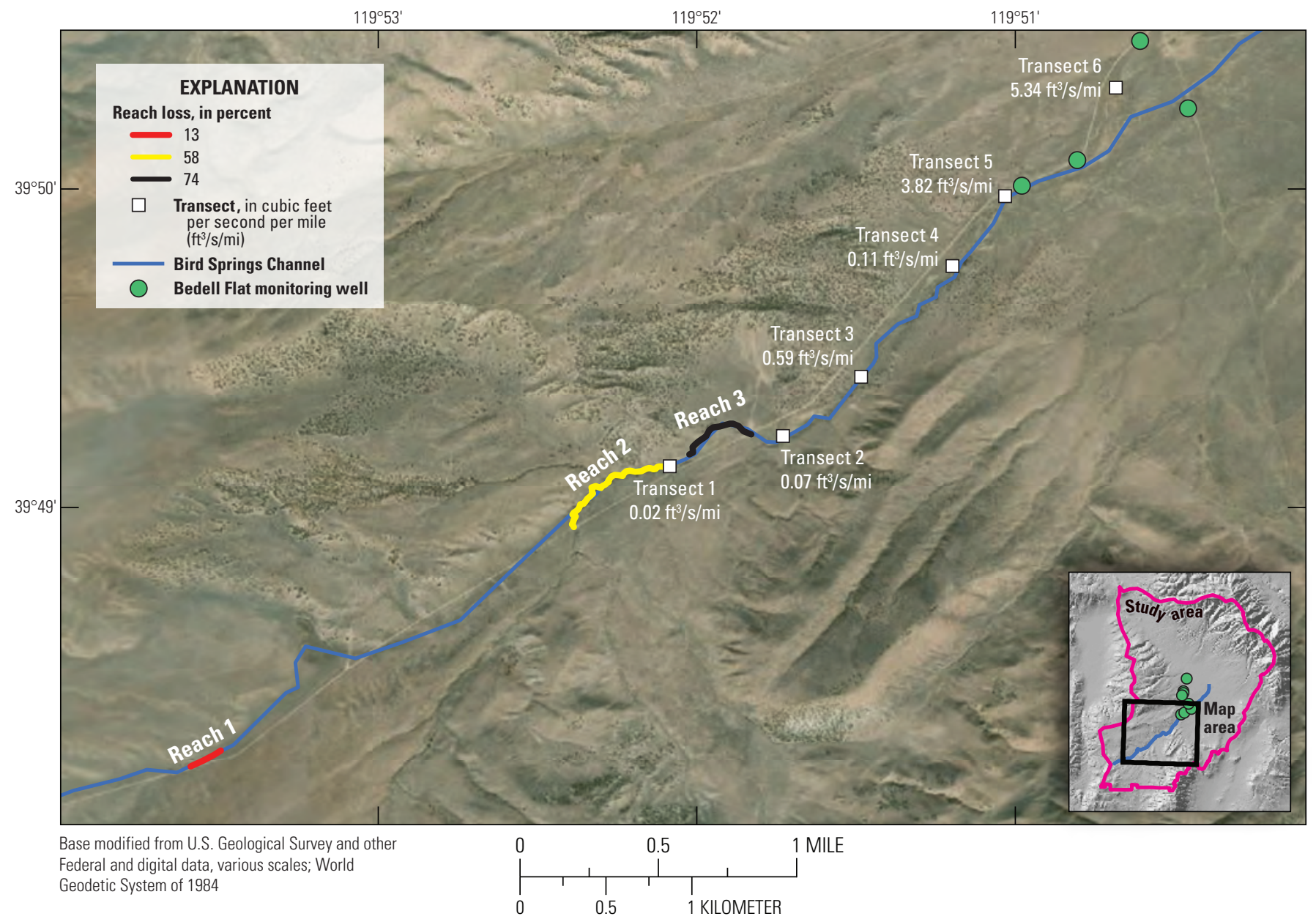

Figure 6. Measured (Reach loss) and modeled (Transect loss) seepage locations along the Bird Springs channel. Seepage run measurement were made for Reach 1 inflow and outflow on March 7, 2017; Reach 2 inflow and outflow on March 14, 2017; and Reach 3 inflow and outflow on March 14, 2017.

The sensors were placed inside a 1-in. polyvinyl chloride pipe with 0.25 -in-diameter perforations and rounded endcaps to prevent damage from debris during runoff. The housing and sensors were flush mounted with rebar in the active channel across from the pressure transducer. Time-lapse cameras were installed on off-channel to vegetation and oriented toward staff gage in the channel. Pressure transducers, ERS, and time-lapse cameras were collected at 10-minute intervals.

\section{Sediment Temperature at Transects}

Temperature rods (TRODs; Naranjo and Turcotte, 2015) containing six sensors spaced at $0,4,8,20,30$, and 40 in. depth were inserted into the bottom of the Bird Springs channel using methods described in Naranjo (2019). The temperature was recorded every 15 -minutes and retrieved from the loggers monthly (Smith and others, 2021). Prior to deployment, the temperature sensors were independently calibrated in a water bath using a five-point linear regression.

Sediments were described at each transect by taking grab samples or by extracting cores. Descriptions were made of each profile to a maximum depth of $2.3 \mathrm{ft}$ to provide visual descriptions of the soil profile, determine textural classification, and identify any visible fine-grained deposits beneath the active channel (table 3 ). The temperature and stage data were used to calibrate numerical seepage models, simulate seepage patterns, and to identify potential low hydraulic conductivity lithologies limiting downward infiltration. 
Table 3. Sediment descriptions from soil core sampling near temperature sensors, Bird Springs channel, Bedell Flat, Washoe County, Nev. Recovery (\%) is the recovered depth divided by the total depth. Total depth is in feet below land surface.

[Recovery (percent) is the recovered depth divided by total depth. Abbreviations: $\mathrm{mm} / \mathrm{dd} / \mathrm{yyyy}$, month/day/year; PST, pacific standard time; ft bls, feet below land surface; ft, foot; - , denotes classification done by hand and not by soil core sampler]

\begin{tabular}{|c|c|c|c|c|c|c|c|}
\hline $\begin{array}{l}\text { Transect } \\
\text { number }\end{array}$ & $\begin{array}{c}\text { Date } \\
\text { sampled } \\
\text { (mm/dd/yyyy) }\end{array}$ & $\begin{array}{l}\text { Time } \\
\text { (PST) }\end{array}$ & $\begin{array}{c}\text { Total } \\
\text { depth } \\
\text { (ft bls) }\end{array}$ & $\begin{array}{l}\text { Recovered } \\
\text { depth } \\
\text { (ft) }\end{array}$ & $\begin{array}{l}\text { Recovery } \\
\text { (percent) }\end{array}$ & $\begin{array}{c}\text { Depth } \\
\text { interval } \\
\text { (ft) }\end{array}$ & Description \\
\hline 1 & $05 / 02 / 2017$ & $16: 15$ & 2.29 & 1.73 & 76 & $\begin{array}{c}0-1.5 \\
1.5-1.73\end{array}$ & $\begin{array}{l}\text { Coarse to fine sand } \\
\text { Silty clay }\end{array}$ \\
\hline 2 & $05 / 02 / 2017$ & $14: 30$ & 2.29 & 1.53 & 67 & $\begin{array}{c}0-0.42 \\
0.42-1.42\end{array}$ & $\begin{array}{l}\text { Coarse to fine sand } \\
\text { Silty clay }\end{array}$ \\
\hline 3 & $05 / 02 / 2017$ & $12: 42$ & 2.29 & 1.76 & 77 & $0-1.76$ & Coarse well-sorted sand \\
\hline 4 & $05 / 02 / 2017$ & $13: 27$ & 2.29 & 1.72 & 75 & $\begin{array}{c}0-0.94 \\
0.94-1.72\end{array}$ & $\begin{array}{l}\text { Coarse sand } \\
\text { Silty loam }\end{array}$ \\
\hline 5 & $06 / 06 / 2018$ & 09:30 & 1.65 & - & - & $0-1.65$ & Coarse sand \\
\hline 6 & $06 / 06 / 2018$ & $10: 15$ & 2.0 & - & - & $0-2.0$ & Coarse sand \\
\hline
\end{tabular}

\section{Model Setup}

Channel seepage rates were estimated by numerical inversions of the VS2DH model (Healy and Ronan, 1996; Hsieh and others, 2000; Naranjo and others, 2021) based on stage and sediment temperature measurements. A cross-sectional channel survey was conducted at each transect using differential Global Position System (GPS) and digital level surveys to define the physical boundaries of the cross-section using USGS survey techniques and methods (Rydlund and Densmore, 2012).

At each transect, the model grids defined in VS2DH were refined near the sediment water interface (fig. 7). Variable grid spacing was used in the vertical and horizontal direction between 0.1 and $0.5 \mathrm{~m}$. The total model domain varied in width depending on the cross-sectional geometry. The model extent varied for each transect in the horizontal and vertical direction between 20 and $50 \mathrm{~m}$, and 10 and $20 \mathrm{~m}$, respectively.

Initial conditions were defined by the temperature observations from the TROD and by assuming initial moisture contents were slightly greater than the residual moisture content of the soil textures defined by the general soil database in VS2DH. The initial moisture content among the different cross-sectional models ranged from 0.05 to 0.15 cubic meter per cubic meter $\left(\mathrm{m}^{3} / \mathrm{m}^{3}\right)$ for the Zone 1 near the sediment-water interface (fig. 7).

Conceptual models for each transect were represented by one to two soil zones with varying head and temperature at the sediment water interface (fig. 7). Lateral extents of the model domain were placed at distances far away from the active channel so that no-flow boundary conditions could be assumed. At the lower boundary, a gravity drainage boundary condition was specified. Channel sediments within each transect were represented by soil zones with uniform hydraulic and thermal properties based on soil texture classifications. Thermal and hydraulic properties are provided in the graphical user interface for VS2DH based on values reported in the literature (Carsel and Parrish, 1988) or were determined by parameter estimation.

Hydraulic parameters that define each soil zone consist of saturated horizontal hydraulic conductivity, porosity, the vertical to horizontal ratio of saturated hydraulic conductivity (henceforth referred to as the anisotropy), and the thermal properties including thermal conductivity at residual and saturated water contents (table 4). The base units used in the model are meters per hour $(\mathrm{m} / \mathrm{h})$, which requires thermal conductivity values as reported in the literature to be converted for unit consistency from watts per meter per degrees Celsius $\left(\mathrm{W} \mathrm{m}^{-1}{ }^{\circ} \mathrm{C}^{-1}\right)$, which is equivalent to joules per second per meter per degrees Celsius $\left(\mathrm{J} \mathrm{s}^{-1} \mathrm{~m}^{-1}{ }^{\circ} \mathrm{C}^{-1}\right)$, to joules per hour per meter per degrees Celsius $\left(\mathrm{J} \mathrm{h}^{-1} \mathrm{~m}^{-1}{ }^{\circ} \mathrm{C}^{-1}\right)$. Measurements of thermal conductivity were taken at residual moisture contents using a thermal conductivity probe (KD2 Pro, Decagon Devices, Pullman, Washington) at the surface, 0.1 and $0.5 \mathrm{~m}$ depths in the field. These measured values were specified in the model as initial estimates for the parameter estimation process. 


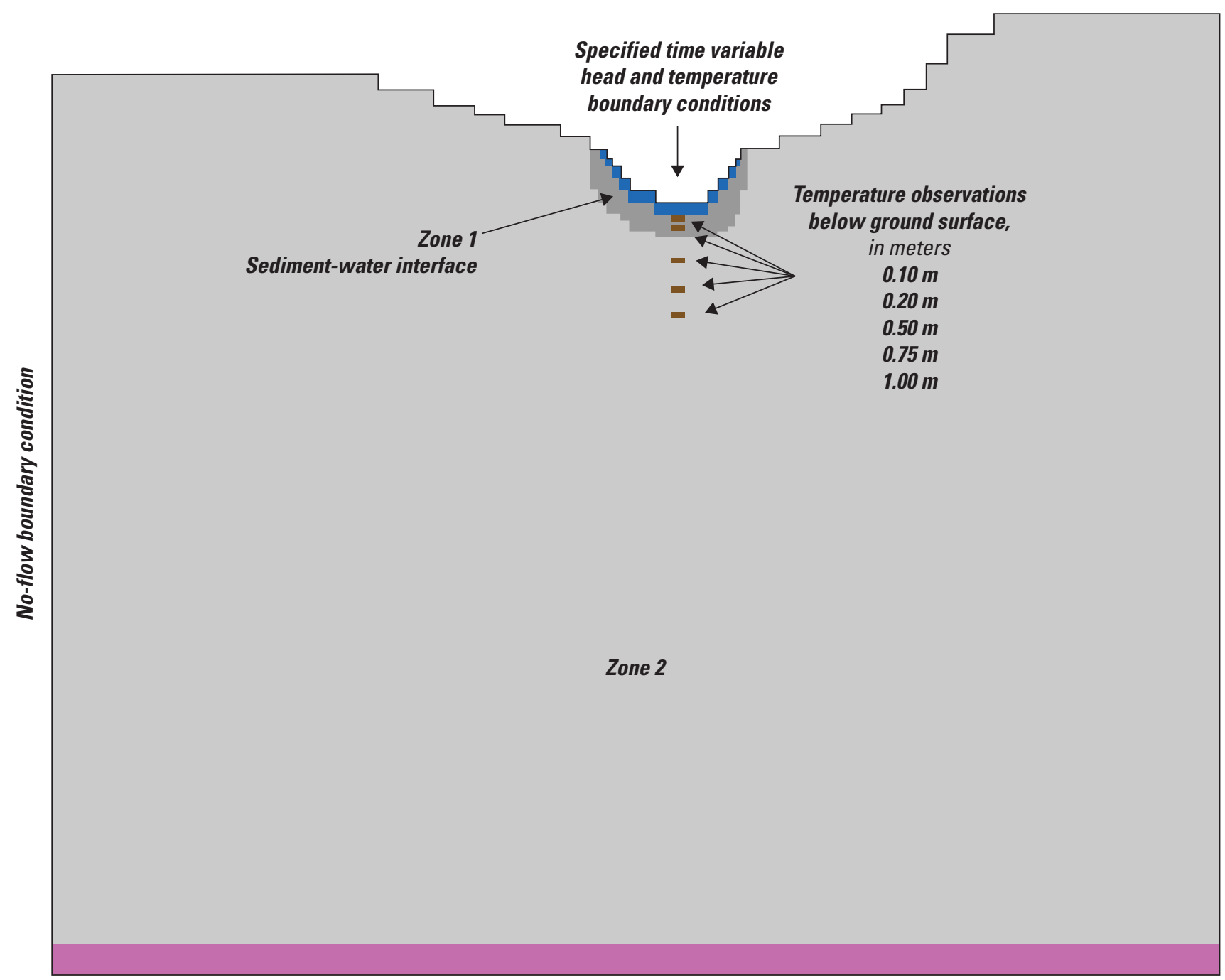

Gravity drainage boundary condition

Figure 7. Two-dimensional conceptual model used to derive seepage estimates from the Bird Springs channel using specified time variable head and temperature boundary conditions.

\section{Model Calibration and Parameter Estimation}

Flow stage, flow duration, and sediment temperature data collected during episodic runoff events were used to estimate hydraulic and thermal properties of channel sediments. The parameter-estimation model, PEST++ (Welter and others, 2015), was applied during model calibration to minimize the root mean square difference (RMSD) between observed and simulated sediment temperatures by automatically adjusting four model parameters: hydraulic conductivity, thermal conductivity at residual moisture, thermal conductivity at saturation, and soil volumetric heat capacity. The PEST ++ is an independent, object-oriented parameter estimation software that executes the VS2DH model and adjusts the parameters using the Gauss-Marquardt-Levenberg optimization algorithm by comparing the simulated temperatures to the observed through a weighted least-squares objective function. The PEST++ automatically re-runs the VS2DH model until the objective function is minimized and provides the final set of estimated parameters. The duration of flow events and the daily variation in temperatures were not substantial enough to use observation and time varying weights, as applied in Naranjo and Smith (2016). Thus, each observation in space and time were given equal weight in the objective function. Default values were specified for soil properties (table 4) not optimized in PEST ++ , based on reported values in Carsel and Parrish (1988) for general soil textural classifications included in VS2DH. Initial parameters values and parameter ranges for PEST++ are also shown in table 4. Individual simulation results are presented in appendix 1. 
Table 4. Summary of hydraulic and thermal parameters as input into the parameter-estimation model to calibrate the VS2DH transect models.

$\left[\mathrm{m} \mathrm{h}^{-1}\right.$, meter per hour; - , dimensionless; $\mathrm{m}^{3} / \mathrm{m}^{3}$, cubic meter per cubic meter; $1 / \mathrm{m}$, one per meter; $\mathrm{m}$, meter; $\mathrm{J} \mathrm{m}^{-3}{ }^{\circ} \mathrm{C}^{-1}$, joules per cubic meter per degree Celsius; $\mathrm{W} \mathrm{m}^{-1}{ }^{\circ} \mathrm{C}^{-1}$, watt per meter per degrees Celsius]

\begin{tabular}{|c|c|c|c|c|}
\hline Parameter description & Symbol & Unit & Value & Source \\
\hline \multicolumn{5}{|c|}{ Hydraulic parameters } \\
\hline Saturated horizontal hydraulic conductivity & $\mathrm{Kx}$ & $\mathrm{m} \mathrm{h}^{-1}$ & $1.0 \times 10^{-4}-10$ & Calibration \\
\hline Specific storage & Ss & $\mathrm{m}^{-1}$ & $1.0 \times 10^{-4}$ & Niswonger and Prudic (2003) \\
\hline Porosity & $\mathrm{n}$ & $\mathrm{m}^{3} / \mathrm{m}^{3}$ & $0.3-0.45$ & Carsel and Parrish (1988) \\
\hline van Genuchten Alpha & $\alpha$ & $\mathrm{m}^{-1}$ & $2-14.5$ & Carsel and Parrish (1988) \\
\hline van Genuchten Beta & $\beta$ & - & $1.4-2.6$ & Carsel and Parrish (1988) \\
\hline \multicolumn{5}{|c|}{ Thermal parameters } \\
\hline Longitudinal dispersivity & $\alpha \mathrm{L}$ & $\mathrm{m}$ & 0.01 & Niswonger and Prudic (2003) \\
\hline Transverse dispersivity & $\alpha \mathrm{T}$ & $\mathrm{m}$ & 0.01 & Niswonger and Prudic (2003) \\
\hline Volumetric heat capacity of water & $\mathrm{Cw}$ & $\mathrm{J} \mathrm{m}^{-3}{ }^{\circ} \mathrm{C}^{-1}$ & $4.2 \times 10^{6}$ & Niswonger and Prudic (2003) \\
\hline
\end{tabular}

${ }^{1}$ Specified in each textural class within VS2DHi (Hsieh and others, 2000) as reported in Carsel and Parrish (1988).

\section{Borehole Sediment Characterization}

Eight boreholes (fig. 4) were drilled and completed as 3 -in. monitor wells (MW) using a roto-sonic boring rig over a period of 5 weeks, beginning on September 23, 2019, and ending on October 31, 2019. Roto-sonic drilling uses a drill head that imparts high-frequency, high-force vibrations into a 10-ft steel pipe, which is rotated and advanced to obtain a continuous, relatively undisturbed sediment sample that is extruded in 2-ft intervals (Barrow, 1994). All wells were completed using 3 -in. polyvinyl chloride, screened (plus or minus $10 \mathrm{ft}$ ) in the water table with only a gravel pack. No grout was used for well completion because the goal of these MWs was primarily for borehole geophysics. Continuous sediment characterization was made in the field. Sediment sample collection was done by (1) form extruded bulk sediment samples collected every 5 -ft (table 2.1 and 2.2), and (2) discrete core samples at 10, 20,30,60, and $100 \mathrm{ft}$ bls collected in advance of the roto-sonic bit (table 2.3). The sonic drilling method requires no fluids for penetration or extrusion, except the occasional need for water to cool the bit as it advances through tight formations. Roto-sonic drilling with a 6-in-diameter bit creates a minimal annular drilling disturbance, which would have allowed the resonant shell of the nuclear magnetic resonance borehole tool to extend into the natural formation. Borehole sediment characterization data, including field and laboratory analyses are available in Smith and others (2021).

\section{Field Characterization of Continuous Sediment}

Continuous sediment samples were extruded in $10-\mathrm{ft}$ sections and bagged at 2-ft intervals. Sediment in each 2-ft bag was photographed (appendix 3), analyzed using a portable soil water content (SWC) sensor, and described for obvious breaks in texture, aggregation or cohesion, and color. Next, field texture was determined using the ball and ribbon tests (appendix 4) in accordance with Soil Science Division Staff (2017). 
A handheld sensor (CS659, Campbell Scientific, Inc., Logan, Utah) was inserted into the extruded sample at 1-ft increments to measure field SWC and bulk electrical conductivity (EC). The sensor uses a transmission line oscillator that sends a square-wave electromagnetic pulse down two, 12-cm rods (Caldwell and others, 2018). The returning pulse triggers subsequent pulses or oscillations which relates SWC to dielectic permittivity, whereas the decrease in pulse amplitude is used to determine the bulk EC. The bulk EC measurement from the sensor was not directly available in the stored data table, only signal attenuation (A). The manufacturer supplied empirical equation (J. Ritter, Campbell Scientific, oral commun., August 30, 2019), used to derive EC from $A$ for the 12 -cm rods of the CS659 probe, is described in the empirical equation below.

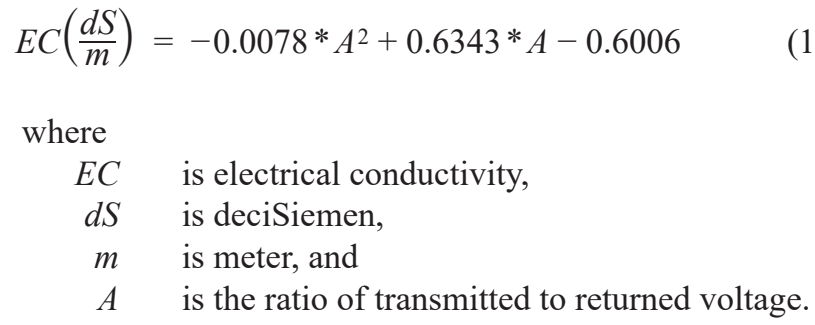

\section{Bulk Sediment Sampling}

A bulk sediment sample (approximately 0.5 kilograms $[\mathrm{kg}])$ was collected from the material extruded from the sonic casing at 5-ft intervals. Bulk sediment samples from the primary wells in Bird Springs (BF-MW-04) and Sand Hills (BF-MW-07) were submitted for laboratory analysis.

\section{Discrete Core Sediment Sampling}

Sediment cores were collected at 10, 20,30,60, and $100 \mathrm{ft}$ bls using a hammer-driven, 18-in. split spoon sampler. The sampler housed three brass cylindrical liners each 6-in. tall and 1.5-in. diameter. The center liner was trimmed, capped, sealed with tape, and secondarily bagged for laboratory analysis. All cores were collected ahead of the sonic bit and beyond any casing advancement. Cores from BF-MW-04 and BF-MW-07 were submitted for commercial laboratory analysis. All other cores were analyzed for water content and bulk density (BD) only.

\section{Laboratory Analysis of Sediments}

Bulk sediment samples were first analyzed in the USGS Nevada Water Science Center soil laboratory for soil moisture using a 20-gram (g) subsample in a stainless-steel sample cup. Matric potential was determined using a WP4C water activity meter (Gee and others, 1992), followed by oven drying for $24 \mathrm{~h}$ at $105^{\circ} \mathrm{C}$ to obtain gravimetric SWC in grams of water per gram of sediment (Gardner, 1986). In addition, 49 discrete sediment cores were emptied to determine SWC and BD by the total wet and dry soil mass and the sampler volume (Grossman and Reinsch, 2002). Volumetric SWC $\left(\mathrm{m}^{3} / \mathrm{m}^{3}\right)$ was determined by multiplying gravimetric SWC by the BD.

Laboratory analyses for geochemical properties were performed by A\&L Western Laboratories (Modesto, California). This laboratory participates in the Soil Science Society of America, North American Proficiency Testing Program, which furnishes agricultural and environmental laboratories with quality control and quality assurance tools through quarterly blind and double-blind statistical evaluation of soil, plant, and water samples. Each method number (for example, S-1.10) below is from Miller and others (2013). Bulk sediment and cores from Bird Springs (BF-MW-04) and Sand Hills (BF-MW-07) drainages were further analyzed for saturated-paste $\mathrm{pH}$ (S-1.10), organic matter by loss-on-ignition (S-9.20), ammonium acetate extractable (S-5.10) ions $\left(\mathrm{K}^{+}\right.$, $\left.\mathrm{Na}^{+}, \mathrm{Ca}^{2+}, \mathrm{Mg}^{2+}\right)$, sulfate as sulfur $\left(\mathrm{SO}_{4}-\mathrm{S}\right)$, nitrate as nitrogen $\left(\mathrm{NO}_{3}-\mathrm{N}\right)$ by $2 \mathrm{~N}$ standard reference solution of potassium chloride $(\mathrm{KCl})$, cadmium reduction (S-3.10), chloride using saturate paste extraction and ion chromatography (S-1.40), total soluble salts (S-1.2) using EC, and particle size (S-14.10) via hydrometer. The soluble anion content (in parts per million) for $\mathrm{NO}_{3}-\mathrm{N}, \mathrm{Cl}^{-}$, and $\mathrm{SO}_{4}-\mathrm{S}$ was converted to pore-water concentration in milligrams per liter $(\mathrm{mg} / \mathrm{L})$ based on the SWC content measured in the laboratory immediately after sampling.

Laboratory quality-assurance methods included verification of the calibration of the analytical balance, thermometers, WP4, drying ovens, and periodic analysis of a 0.5 molal $\mathrm{KCl}$ solution. Instruments were re-calibrated as appropriate, and analyses showed no sources of measurable systematic bias to the environmental samples. Laboratory duplicate analysis was performed on 10 percent of the bulk sediment samples, including those submitted to A\&L Western Labs. For each laboratory duplicate pair, the relative percentage difference (RPD) was calculated as the absolute difference divided by their mean. The mean RPD was then determined for all duplicate pairs, which is considered ideal for soil analyses if RPD less than 30 percent.

\section{Results of Seepage Loss Estimates}

Direct estimates of seepage loss along the Bird Springs channel were made using differential gaging. Indirect estimates were obtained using the numerical model VS2DH and parameter optimization of hydraulic properties by reducing the error between simulated and observed in-channel measurement of sediment temperatures with depth. The model results were used to estimate seepage loss at standardized stages and then compared to direct loss estimates. 


\section{Seepage-Run Measurements}

In March 2017, seepage runs were measured at three reaches (fig. 6) in the Bird Springs drainage to estimate seepage loss (table 5). Seepage loss rates for reaches along the Bird Springs channel varied from 0.1 to $0.29 \mathrm{ft}^{3} / \mathrm{s} / \mathrm{mi}$ for flow rates ranging from 0.01 to $0.24 \mathrm{ft}^{3} / \mathrm{s}$. The channel water-column depth was less than $0.5 \mathrm{ft}$ for all seepage run measurement locations. Reach losses tended to increase down the Bird Springs channel (fig. 6).

Seepage rates estimated by runoff events provide valuable insight into the spatial variability; however, they also require considerable effort and logistics to overcome with remote field sites in arid climates. For example, seepage runs were not possible in WY 2018 because of flow rates exceeding the upper limits of the flumes $\left(1 \mathrm{ft}^{3} / \mathrm{s}\right)$ and multiple inputs from minor tributaries and roads between reaches that were infeasible to measure during the short runoff events (fig. 5F). Additionally, the "flashy" drainage response to episodic events made minimizing flow measurement error impractical, or greater than 10 percent, when flows were greater than $1 \mathrm{ft}^{3} / \mathrm{s}$. For WY 2017 and WY 2018, estimates of seepage losses could be made along instrumented transects where stage and sediment temperatures were used in the VS2DH numerical heat and flow models. Because seepage loss rates can be highly dependent on stage, estimates made by VS2DH provided a more useful comparison between transect seepage rates.

\section{Estimates of Model Parameters}

The objective of parameter optimization was to estimate hydraulic and thermal properties of channel sediment during natural runoff events then allow the model to solve for the volume of water loss into the channel sediments. The calibrated models were then used to estimate seepage-loss rates for prescribed conditions of uniform stage; this was done because short duration runoff events may have rapid changes in stage and lead to seepage rates that have not reached steady state. Thus, the calibrated models at each transect were used to predict seepage rates at steady state conditions for multiple stage levels; this allowed a more consistent comparison between transects. Model accuracy is dependent on initial conditions, such as moisture content and temperature, as well as initial hydraulic and thermal properties. Parameters such as hydraulic conductivity, porosity, and heat capacity are among the parameters most sensitive to temperature simulations (Naranjo and Smith, 2016). The hydraulic conductivity predominantly influences seepage rates under saturated conditions (Constantz, 2008).

Table 5. Seepage losses between reaches of the Bird Springs channel measured in March 2017.

[mm/dd/yyyy, month/day/year; $\mathrm{ft}^{3} / \mathrm{s}$, cubic feet per second; $\mathrm{ft}$, foot; mi, mile]

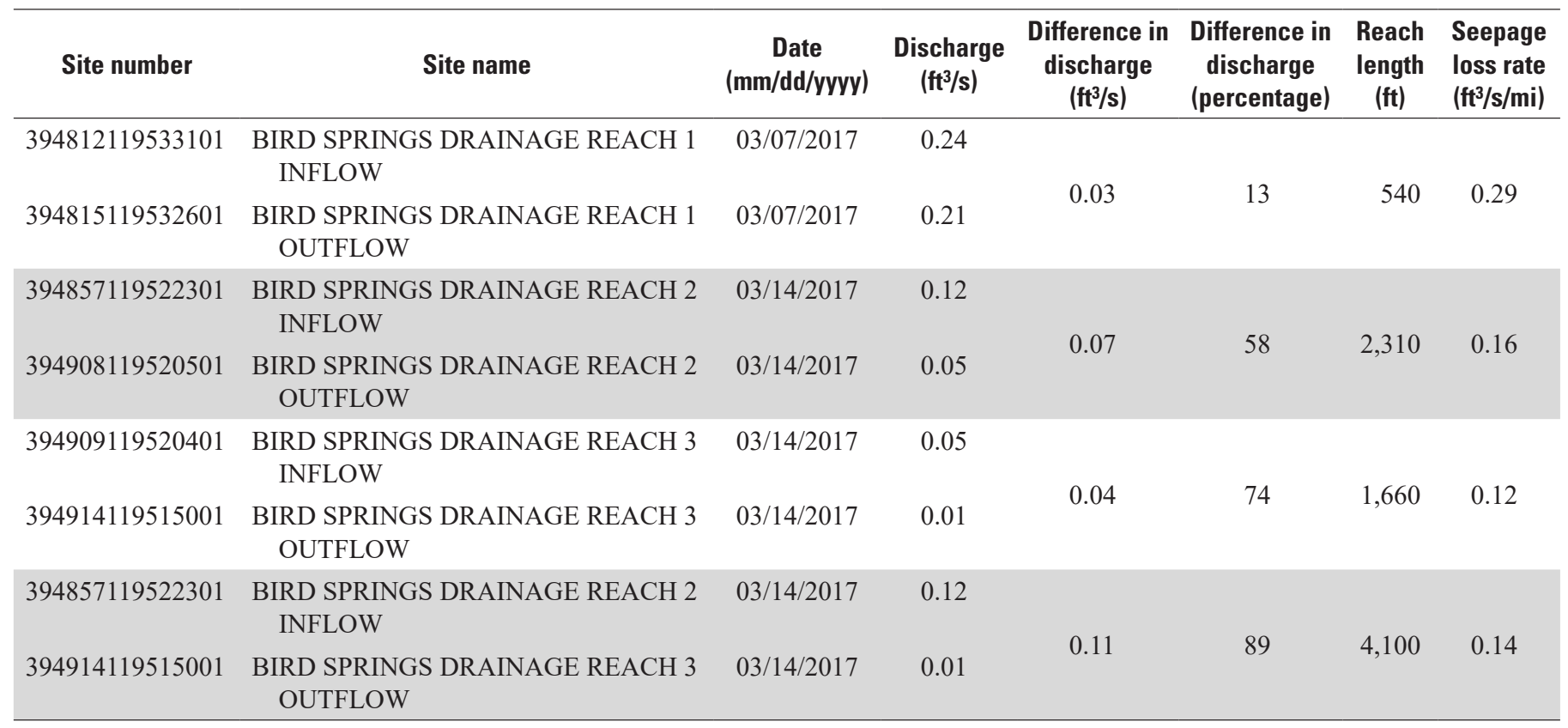


For flow events that are less than $48 \mathrm{~h}$ in duration, uncertainty of simulated temperature and seepage rates is introduced by inadequately defining the onset and termination of flow and potential changes in permeability resulting from scour or sedimentation. To determine the flow duration in the channel, data collected by pressure transducers, time-lapse cameras, and flow sensors were evaluated (Smith and others, 2021). At Transects 1 and 2 (fig. 6), the duration of model calibration was $148 \mathrm{~h}$. For Transects 3-6, a single flow event that lasted $22 \mathrm{~h}$ was used to estimate hydraulic and thermal properties. The RMSD, a measure of how well the model reproduces the measured sediment temperatures, during calibration ranged from 0.1 to $1.1^{\circ} \mathrm{C}$ (median equals $0.3{ }^{\circ} \mathrm{C}$ ) for all observations (table 6). With equal weights assigned to all observations, the model objective function was minimized by the optimal set of hydraulic and thermal parameters.

The optimized thermal and hydraulic properties estimated for each transect (fig. 6) are shown in table 7. The optimized hydraulic conductivity of channel sediments at Transects 1 and 2 were among the lowest values $(0.001-0.14 \mathrm{~m} / \mathrm{h})$. The sediment cores taken from Transect 1 were identified as having a silty clay material between 0.46 and $0.53 \mathrm{~m}$ bls with coarse to fine sediment from 0 to $0.46 \mathrm{~m}$ (table 3). At Transect 2 , silty clay was present at $0.13-0.47 \mathrm{~m}$ below a coarse-to-fine sand from 0 to $0.13 \mathrm{~m}$. Overall, model estimates of hydraulic conductivity were consistent with qualitative descriptions of the soil cores. Further, Transects 1 and 2 were located downgradient of surface drainage from the Bird Springs Road where lateral erosion also may have contributed fine sediment to channel sediments. At Transects 5 and 6, the sediment core sampling identified a relatively homogeneous coarse sand from the surface to $0.61 \mathrm{~m}$ and one zone was used to

Table 6. Model calibration root mean square difference (RMSD) for each temperature sensor depth below land surface at the six transects. All RMSD values are in degrees Celsius.

[m, meter]

\begin{tabular}{lcccccc}
\hline Transect & $\mathbf{0 . 1 0} \mathbf{~}$ & $\mathbf{0 . 2 0} \mathbf{~}$ & $\mathbf{0 . 5 0} \mathbf{~}$ & $\mathbf{0 . 7 5} \mathbf{~}$ & $\mathbf{1 . 0 0} \mathbf{~}$ & $\begin{array}{c}\text { Total } \\
\text { RMSD }\end{array}$ \\
\hline 1 & 0.59 & 0.53 & 0.25 & 0.54 & 0.23 & 0.51 \\
2 & 0.18 & 0.23 & 0.16 & 0.29 & 0.68 & 0.22 \\
3 & 0.29 & 0.23 & 0.44 & 0.33 & 0.16 & 0.21 \\
4 & 0.44 & 0.29 & 0.09 & 0.19 & 0.31 & 0.29 \\
5 & 0.44 & 0.32 & 0.34 & 0.29 & 0.47 & 0.38 \\
6 & 0.54 & 1.05 & 0.85 & 0.16 & 0.38 & 0.73 \\
\hline Minimum & 0.18 & 0.23 & 0.09 & 0.16 & 0.16 & 0.21 \\
Maximum & 0.59 & 1.05 & 0.85 & 0.54 & 0.68 & 0.73 \\
Median & 0.44 & 0.30 & 0.29 & 0.29 & 0.34 & 0.33 \\
\hline
\end{tabular}

estimate bulk hydraulic and thermal properties during model calibration. The estimated hydraulic conductivity was among the highest for these transects at 0.5 and $0.6 \mathrm{~m} / \mathrm{h}$.

Subsurface temperatures measured and simulated by VS2DH at Transect 1 during the calibration period from February 3, 2017, at 4:00:00 a.m. to February 8, 2017, at 11:00:00 p.m. (140 h) are shown on figure 8 (similar figures for Transects 2-6 are available in appendix 1). At Transect 1, the best solution from PEST between simulated and observed temperatures resulted in a RMSD of $0.5^{\circ} \mathrm{C}$ (table 6). Overall, the simulated temperatures were within reasonable agreement with measured temperatures (RMSD $0.1-0.7^{\circ} \mathrm{C}$ ).

\section{Seepage Loss Estimates at Transects using Calibrated Models}

During WY 2017, instrumentation was deployed for temperature-based estimates of seepage at Transects 1 and 2 during three periods from February 3, 2017, to March 16, 2017 (fig. 9). The average loss rate estimated at Transect 1 was $0.025 \mathrm{ft} /$ day given an average stage of $0.33 \mathrm{ft}$ (fig. $9 A$ ). During the same period of simulation, the seepage rates were estimated to be $0.074 \mathrm{ft} /$ day at Transect 2 given an average stage of $0.33 \mathrm{ft}$ (fig. 9B). The estimated seepage rates at both transect sites are influenced by the presence of low permeability sediments as observed in the sediment cores.

Instrumentation placed in the channel in WY 2018 captured only one runoff event at Transects 3-6 on March 22, 2018 (fig. 10). The observed stage at these transects was less than $1 \mathrm{ft}$ during this $22 \mathrm{~h}$ runoff event. At Transect 3 , the average seepage rate estimated was $1.2 \mathrm{ft} /$ day, 16 times greater than Transect $2(0.074 \mathrm{ft} /$ day $)$ for a similar average stage $(0.33 \mathrm{ft})$. Despite the average stage at Transect $4(0.6 \mathrm{ft})$ being nearly two times greater than Transect $3(0.35 \mathrm{ft})$, the average seepage rates were $0.51 \mathrm{ft} / \mathrm{day}$, a decrease of 56 percent compared to Transect 3 . At Transect 5 and 6 , where channel sediments consisted mostly of coarse sand, seepage rates increased an order of magnitude from Transect 4 to 5.2 and $5.6 \mathrm{ft} /$ day, respectively. Average stage conditions for Transect 5 and 6 during this runoff event were 0.4 and $0.5 \mathrm{ft}$, respectively.

As illustrated in these natural runoff events (figs. 9 and 10), the observed runoff stage fluctuates as snowmelt and watershed conditions alter the amount of runoff to the channel. The simulated seepage loss rates increase with stage in the channel and a direct comparison between transects is not possible because each location has a different stage-seepage loss relation. In-channel MAR would create a more constant stage as discharge would be remain at 2 MGD at the top of the reach but would progressively decrease in flow and stage with distance down gradient as more water is lost to seepage. 
Table 7. Optimized and default model parameters used for model simulations at each transect.

$[\mathrm{Kx}$, saturated horizontal hydraulic conductivity; *, optimized parameter obtained from Parameter-ESTimation code (PEST); $\mathrm{mh}^{-1}$, meters per hour; $\mathrm{n}$, porosity; $\mathrm{m}^{3} / \mathrm{m}^{3}$, cubic meter per cubic meter; $\varphi$, residual moisture content; $\alpha$, van Genuchten Alpha; m, meter; $\beta$, van Genuchten Beta; $\mathrm{Cs}$, volumetric heat capacity of solids; $\mathrm{J} \mathrm{m}^{-3}{ }^{\circ} \mathrm{C}^{-1}$, joules per cubic meter per degrees Celsius; Ktr, thermal conductivity of sediments at residual moisture content; $\mathrm{W} \mathrm{m}^{-1}{ }^{\circ} \mathrm{C}^{-1}$, watt per meter degrees Celsius; Kts, thermal conductivity of saturated sediments]

\begin{tabular}{|c|c|c|c|c|c|c|c|c|}
\hline $\begin{array}{l}\text { Soil } \\
\text { zone }\end{array}$ & $\begin{array}{c}K x^{*} \\
\left(\mathbf{m h}^{-1}\right)\end{array}$ & $\begin{array}{c}n \\
\left(m^{3} / m^{3}\right)\end{array}$ & $\begin{array}{c}\varphi \\
\left(\mathrm{m}^{3} / \mathrm{m}^{3}\right)\end{array}$ & $\underset{\left(m^{-1}\right)}{\alpha}$ & $\beta$ & $\begin{array}{c}\mathrm{Cs}^{*} \\
\left(\times 10^{6} \mathrm{~J} \mathrm{~m}^{-3}{ }^{\circ} \mathrm{C}^{-1}\right)\end{array}$ & $\begin{array}{c}\mathrm{Ktr}^{*} \\
\left(\mathrm{~W} \mathrm{~m}^{-1}{ }^{\circ} \mathrm{C}^{-1}\right)\end{array}$ & $\begin{array}{c}\mathrm{Kts}^{*} \\
\left(\mathrm{~W} \mathrm{~m}^{-1}{ }^{\circ} \mathrm{C}^{-1}\right)\end{array}$ \\
\hline \multicolumn{9}{|c|}{ Transect 1: Sandy loam } \\
\hline 1 & 0.001 & 0.41 & 0.15 & 7.5 & 1.9 & 1.10 & 1,900 & 9,720 \\
\hline 2 & 0.02 & 0.41 & 0.15 & 7.5 & 1.9 & 1.10 & 300 & 2,000 \\
\hline \multicolumn{9}{|c|}{ Transect 2: Sandy loam } \\
\hline 1 & 0.002 & 0.41 & 0.00 & 7.5 & 1.9 & 0.50 & 502 & 7,880 \\
\hline 2 & 0.14 & 0.41 & 0.00 & 7.5 & 1.9 & 2.83 & 321 & 3,161 \\
\hline \multicolumn{9}{|c|}{ Transect 3: Loamy sand } \\
\hline 1 & 0.09 & 0.35 & 0.06 & 8.0 & 2.3 & 1.10 & 1,859 & 9,720 \\
\hline 2 & 0.07 & 0.35 & 0.10 & 8.0 & 2.3 & 1.10 & 1,900 & 7,069 \\
\hline \multicolumn{9}{|c|}{ Transect 4: Loamy sand } \\
\hline 1 & 0.13 & 0.35 & 0.06 & 10.1 & 2.3 & 0.59 & 1,248 & 6,700 \\
\hline 2 & 0.01 & 0.35 & 0.06 & 11.7 & 2.3 & 3.00 & 1,615 & 4,747 \\
\hline \multicolumn{9}{|c|}{ Transect 5: Loamy sand } \\
\hline 1 & 0.50 & 0.35 & 0.06 & 6.6 & 2.3 & 3.00 & 730 & 8,340 \\
\hline \multicolumn{9}{|c|}{ Transect 6: Loamy sand } \\
\hline 1 & 0.59 & 0.35 & 0.06 & 8.1 & 2.3 & 2.99 & 1,774 & 8,326 \\
\hline
\end{tabular}

Calibrated model simulations at each transect were run for $500 \mathrm{~h}$ at prescribed stage levels (fig. 11). The stage-seepage loss relation was calculated by fitting a first- or second-order regression through the simulated seepage loss rates. For comparison, at $1 \mathrm{ft}$ of stage, the loss rates at each transect ranged from 0.02 to $5.3 \mathrm{ft}^{3} / \mathrm{s} / \mathrm{mi}$, with Transect 1 and 2 resulting in minimal loss. At Transect 5 and 6 , loss rates were two orders of magnitude greater, 3.8 and $5.3 \mathrm{ft} 3 / \mathrm{s} / \mathrm{mi}$ for $1 \mathrm{ft}$ of stage, respectively.

These stage-seepage regressions were used to evaluate the seepage losses associated with imported water for in-channel MAR down the Bird Springs channel and to estimate the distance 2 MGD $\left(4 \mathrm{ft}^{3} / \mathrm{s}\right)$ would travel starting from Transect 1. To account for a stage reduction that occurs with downstream seepage loss, a stage-discharge relation was estimated (fig. 12) using a Manning's roughness coefficient of 0.04 based on the cobbles and bank vegetation observed and applied to the wetted cross-sectional area at each transect (Chow, 1959). Using the stage-discharge and the stage-seepage regressions (fig. 11), an estimate of the losses down the channel can be made. For example, $4 \mathrm{ft}^{3} / \mathrm{s}$ would result in $0.3 \mathrm{ft}$ of stage at Transect 1 based on the stage-discharge regression. Appling the stage-seepage regression, $0.3 \mathrm{ft}$ would result in $0.01 \mathrm{ft} / \mathrm{s} / \mathrm{mi}$ or 0.1 percent loss per reach between Transect 1 and 2 (table 8 ). However, from Transect 3 to 5,6 to 8 percent of $4 \mathrm{ft}^{3} / \mathrm{s}$ discharge would be reduced by seepage loss. A more substantial 40 percent of the flow would be lost to seepage between Transect 5 and Transect 6 . Based on this analysis, 100 percent of the $4 \mathrm{ft}^{3} / \mathrm{s}$ discharge imported into Bird Springs channel at Transect 1 would infiltrate by $0.6 \mathrm{mi}$ downgradient of Transect 6 . 


\section{Transect 1}
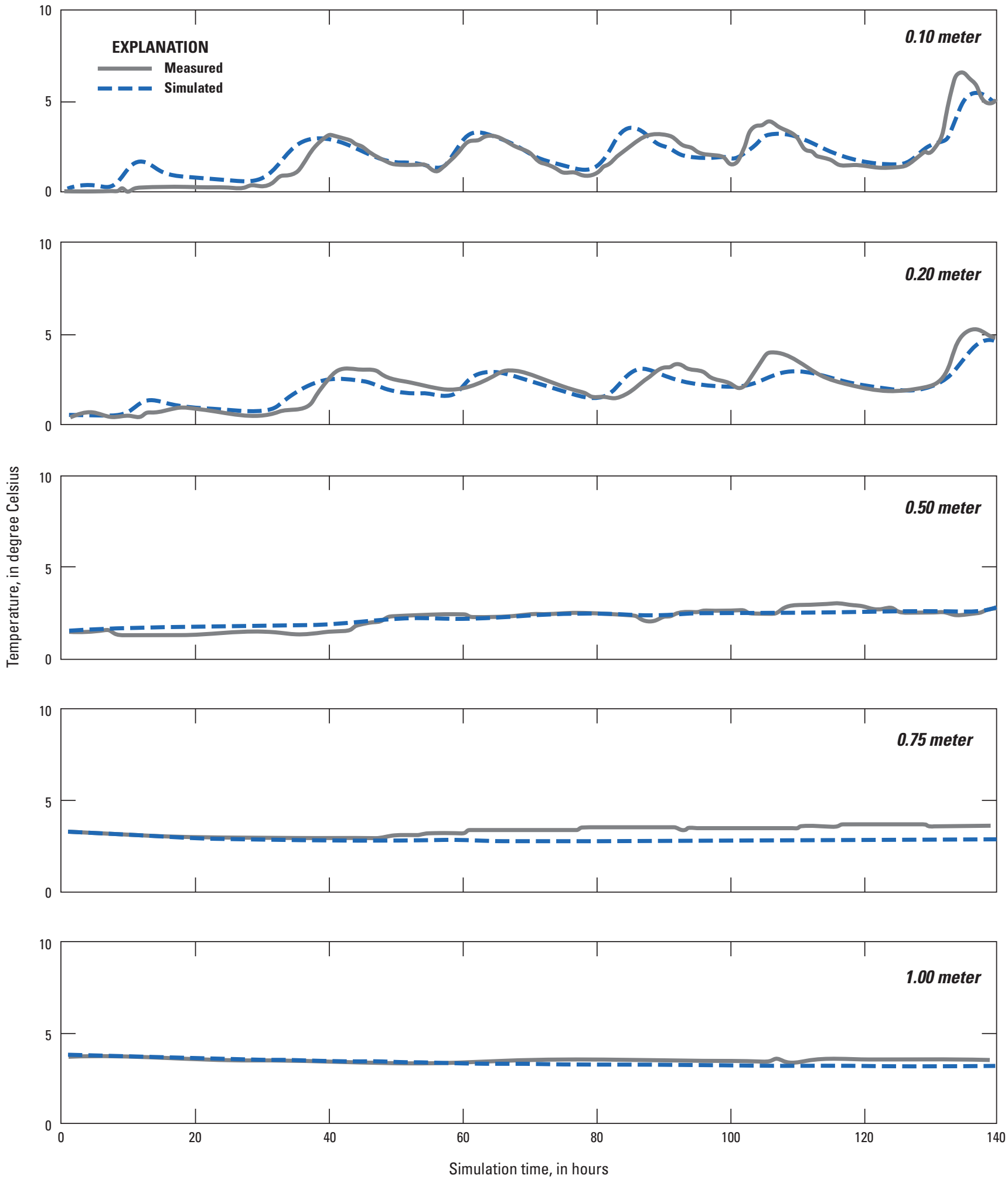

Figure 8. Simulated and observed sediment temperatures at Transect 1 for depths $0.10,0.20,0.50,0.75$ and $1.00 \mathrm{~meter}(\mathrm{~m})$ below land surface during the calibration period from February 3, 2017, at 4:00 a.m. to February 8, 2017, at 11:00 p.m. 
$\boldsymbol{A}$
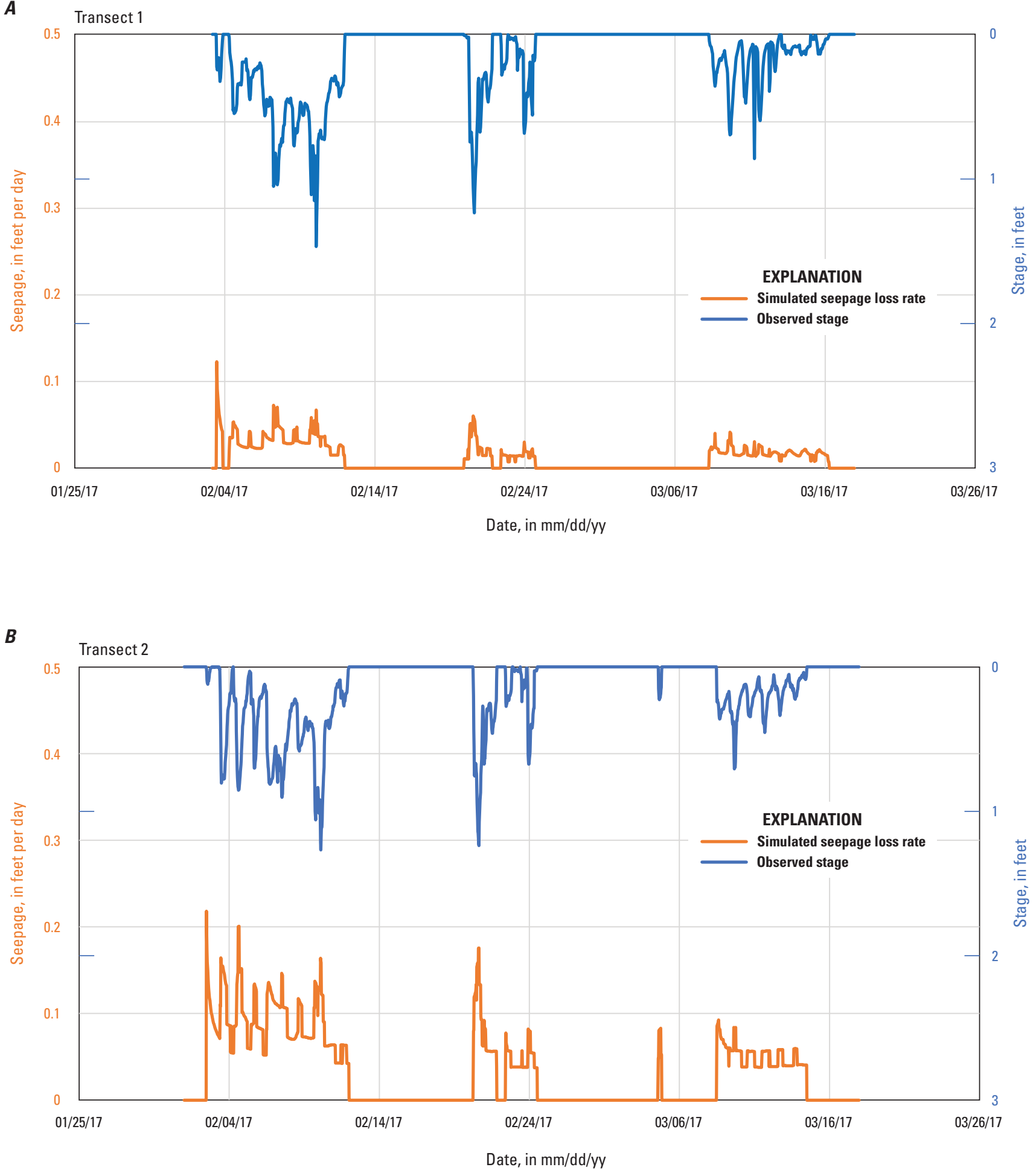

Figure 9. Observed runoff stage (blue line) and simulated seepage loss rates (orange line) for $A$, Transect 1 and $B$, Transect 2 from February 3, 2017, to March 15, 2017. Zero stage corresponds to no flow in channel. 
$\boldsymbol{A}$

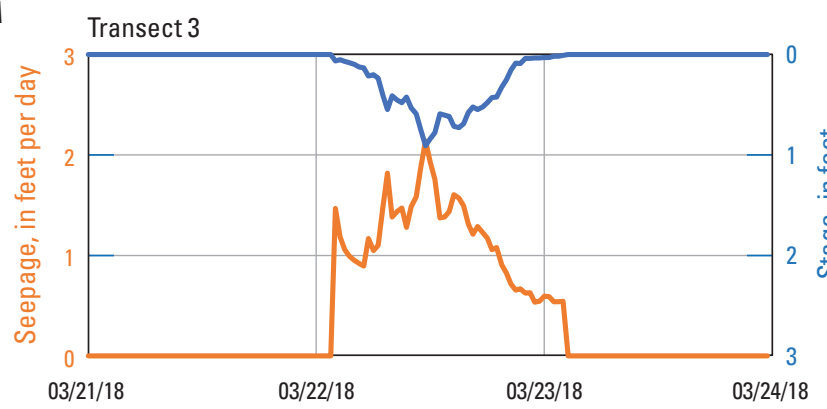

c

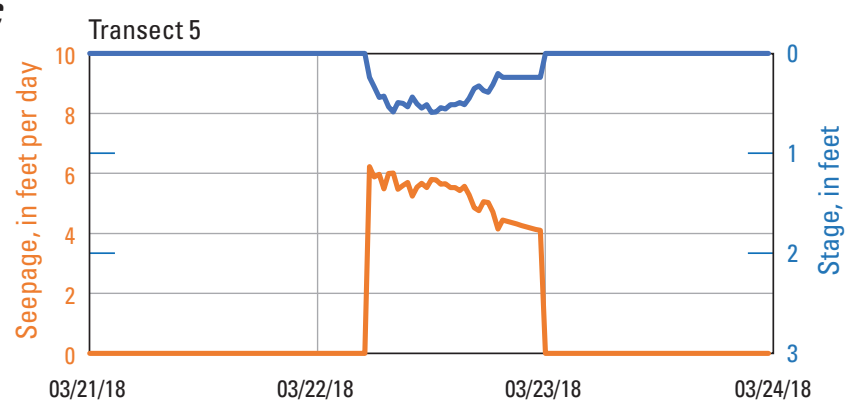

B

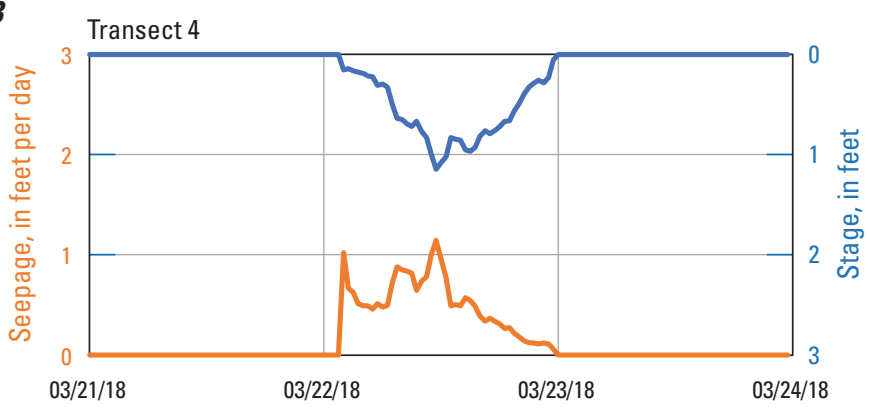

D Transect 6

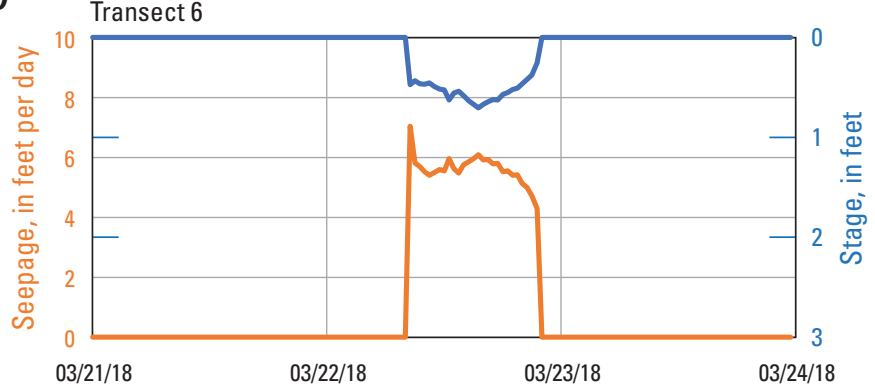

EXPLANATION

Simulated seepage loss rate

Observed stage

Figure 10. Observed stage (blue line) and simulated seepage loss rates (orange line) for $A$, Transect 3, $B$, Transect 4, $C$, Transect 5 , and $D$, Transect 6 from March 21, 2018, to March 24, 2018. Zero stage corresponds to no flow in channel.

Table 8. Estimated seepage losses along the Bird Springs channel from Transect 1 to 6 assuming 4 cubic feet per second of imported water.

[ft, foot; $\mathrm{ft}^{3} / \mathrm{s}$, cubic foot per second; mi, mile]

\begin{tabular}{|c|c|c|c|c|c|c|}
\hline Channel reach & $\begin{array}{c}\text { Distance } \\
\text { (mile) }\end{array}$ & $\begin{array}{c}\text { Stage based } \\
\text { on inflow } \\
\text { (ft) }\end{array}$ & $\begin{array}{c}\text { Seepage } \\
\text { loss } \\
\left(\mathrm{ft}^{3} / \mathrm{s} / \mathrm{mi}\right)\end{array}$ & $\begin{array}{c}\text { Seepage loss } \\
\text { per reach } \\
\left(\mathrm{ft}^{3} / \mathrm{s}\right)\end{array}$ & $\begin{array}{c}\text { Discharge } \\
\text { estimate } \\
\left(\mathrm{ft}^{3} / \mathrm{s}\right)\end{array}$ & $\begin{array}{c}\text { Reduction in } \\
\text { discharge } \\
\text { (percent) }\end{array}$ \\
\hline Transect 1 to 2 & 0.5 & 0.31 & 0.02 & 0.0 & 3.99 & 0 \\
\hline Transect 2 to 3 & 0.4 & 0.19 & 0.03 & 0.0 & 3.98 & 1 \\
\hline Transect 3 to 4 & 0.6 & 0.61 & 0.4 & 0.2 & 3.76 & 6 \\
\hline Transect 4 to 5 & 0.3 & 0.65 & 0.2 & 0.1 & 3.69 & 8 \\
\hline Transect 5 to 6 & 0.5 & 0.38 & 2.5 & 1.3 & 2.44 & 39 \\
\hline Transect 6 to downstream & 0.6 & 0.44 & 3.5 & 2.5 & 0 & 100 \\
\hline
\end{tabular}



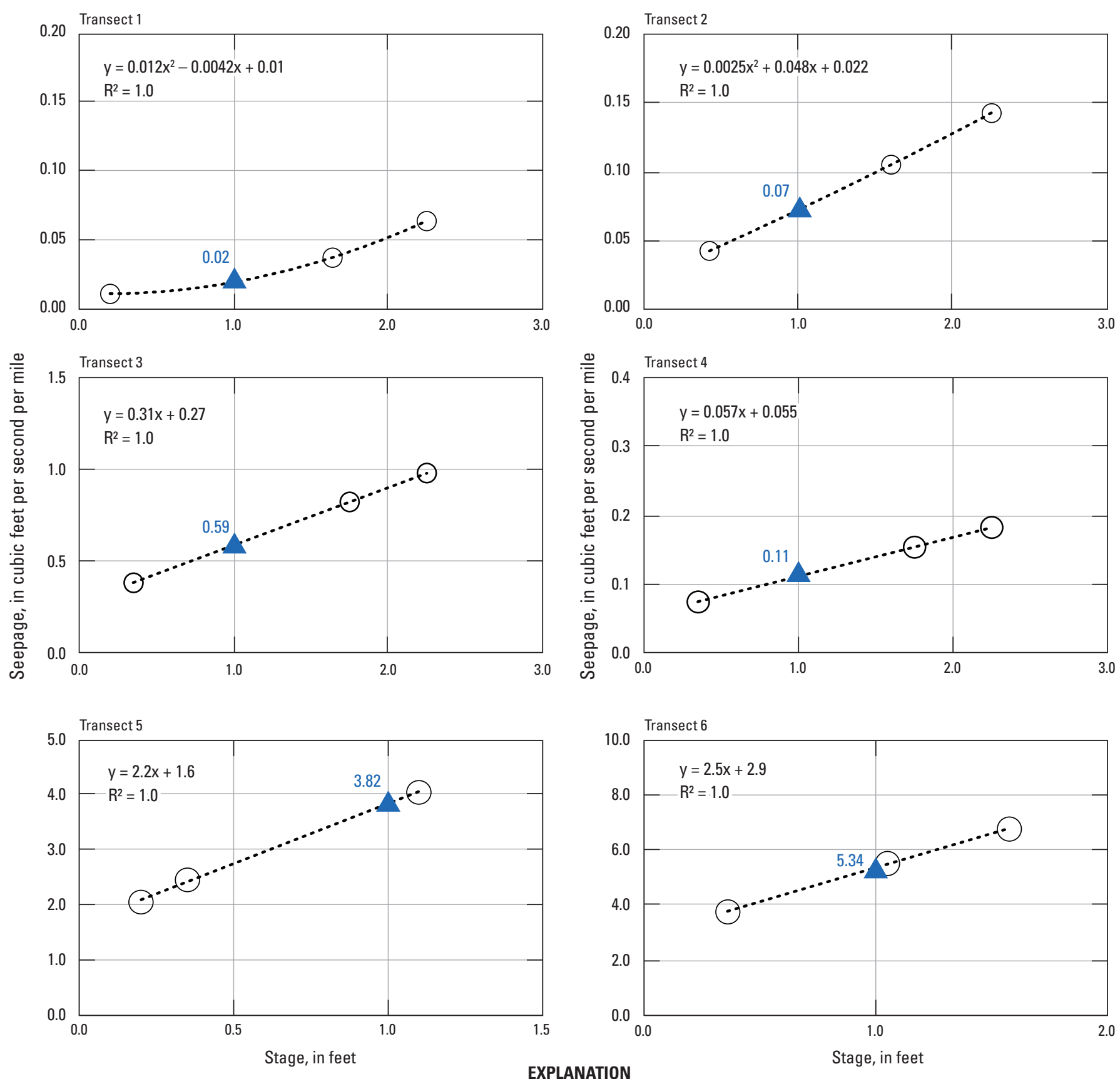

\section{EXPLANATION}

Stage, in feet

Standardized seepage loss rate for 1 foot of stage

Simulated steady-state stage

Figure 11. Simulated steady-state seepage loss rates for standardized stage conditions. The coefficient of determination, $R^{2}$, is shown for each equation. 

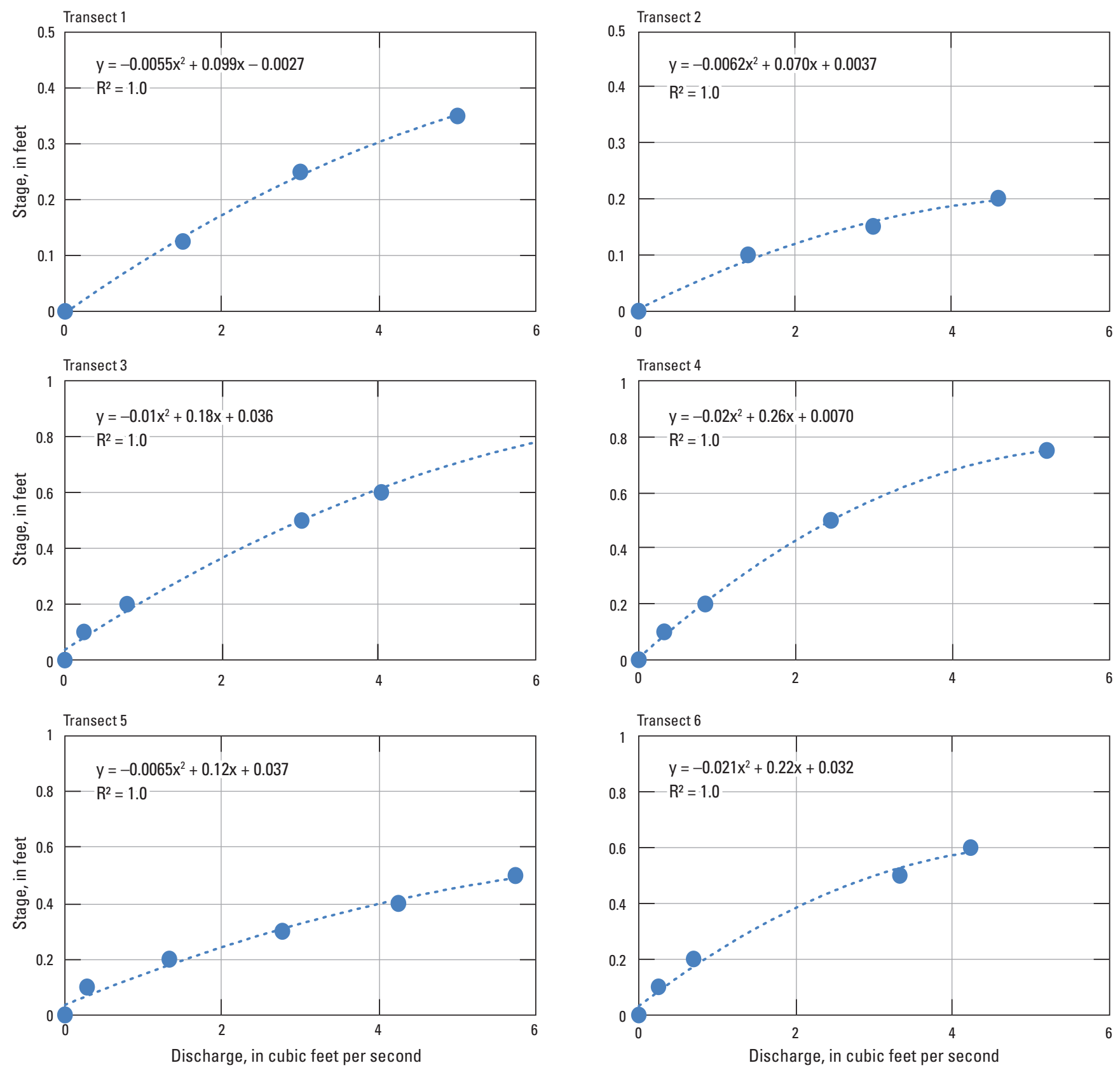

Figure 12. Stage-discharge regressions estimated from Manning's equation for Transects 1-6. 


\section{Results of Unsaturated Zone Characterization}

Borehole locations were chosen by TMWA to represent potential areas for RIB locations. More conductive zones of sand and gravel are typically targeted for RIBs, but these deposits tend to be lenticular and challenging to spatially characterize and model (Maples and others, 2019). Any heterogeneity or anisotropy of the unsaturated zone for in-channel MAR or RIB should be identified and evaluated to ensure efficient ASR (Bouwer and others, 1999). For the purposes of this study, unsaturated zone characterization data were collected from (1) field characterization of continuous sediment samples, (2) laboratory analysis of bulk sediment at 5 - $\mathrm{ft}$ intervals to the water table, and (3) discrete soil cores at 10, 20, 30, 40, 60, and $100 \mathrm{ft}$. These datasets were evaluated by comparing field characterization of continuous soil moisture and texture with discrete samples and laboratory analyses of sediment particle size, moisture, and geochemical profiles.

\section{Borehole Moisture Profiles and Stratigraphy}

Eight boreholes, four along Bird Springs and four along Sand Hills drainages, were drilled to the water table using roto-sonic technology (fig. 4). Detailed analyses were focused on the two boreholes situated at the most ideal locations for potential RIBs, which include BF-MW-04 in the Bird Springs drainage and BF-MW-07 in the Sand Hills drainage.

The SWC and field texture from nearly continuous extruded sediment provided detailed stratigraphic information (appendix 2; Smith and others, 2021), particularly related to perched zones of moisture residing on dry, fine-textured clays. These layers were more evident at BF-MW-04 in the granitic/ volcanic watershed of Bird Springs (fig. 13A) than BF-MW-07 in the Sand Hills drainage (fig. 13E). For example, at borehole BF-MW-04, the first $28 \mathrm{ft}$ bls of sediment were coarse sands or loamy sands with progressively increasing SWC reaching $0.30 \mathrm{~m}^{3} / \mathrm{m}^{3}$ (fig. 13A) until a fine-grained 5-ft-thick layer of silt loam was encountered (fig. 13C). The laboratory SWC in bulk samples and cores showed similar increases in SWC with depth; however, the heterogeneity of these datasets was less pronounced than the continuous field SWC data. The cores had a nearly constant SWC of $0.40 \mathrm{~m}^{3} / \mathrm{m}^{3}$ from 30 to $150 \mathrm{ft}$ bls, whereas continuous field SWC indicated at least six layers with SWC exceeding $0.30 \mathrm{~m}^{3} / \mathrm{m}^{3}$. However, matric potentials remained nearly constant around values of $-10 \mathrm{~m}$ to a depth of $80 \mathrm{ft}$ bls, then $-20 \mathrm{~m}$ to $150 \mathrm{ft}$ bls (fig. 13B). The hydraulic gradient (change in matric potential with depth) was consistent indicating a low vertical flux. The relatively substantial increase in matric potential (presented in absolute units e plotted in log scale) from 140 to $150 \mathrm{ft}$ corresponds to a thick layer of clay loam (fig. 14E) making it very unlikely that any natural recharge has percolated vertically through these layers in some time. The variability in SWC and matric potential are primarily related to changes in soil texture with wet conductive sands sitting atop drier clays impeding downward percolation and creating perched zones of water that move laterally along the sand-clay contact.

In the sandstone-derived sediments of the Sand Hills drainage, the lithology at BF-MW-07 was a more homogeneous, coarse sand to $150 \mathrm{ft}$ bls with two discrete layers of sandy loam at 30-35 and 41-48 ft bls, and a thin layer of sandy clay loam from 74 to $76 \mathrm{ft}$ bls (fig. 14H). Each of these layers of low permeability impede vertical flow and create an elevated SWC, indicating a perched zone of moisture. Within this first zone of sandy loam, matric potential increases from -10 to $-80 \mathrm{~m}$, indicating little flux has moved vertically below $40 \mathrm{ft}$ bls (fig. 14F). An 8-ft-thick layer of sandy clay loam at $160 \mathrm{ft}$ bls had very low matric potential $(-1,000 \mathrm{~m})$ indicating water was neither percolating down as potential recharge nor wicking upward from the saturated zone beneath.

The land surface elevation of boreholes BF-MW-04 and BF-MW-07 were 5,096 and 5,087 ft, respectively, with the same depth to water of $180 \mathrm{ft}$ bls. When the deepest clay layers above the water table were penetrated during drilling, sands and loamy sands were saturated beneath and groundwater rose into the sonic core barrel at both sites, indicating some confining pressure in the aquifer.

Summary statistics for the physical characterization of the bulk sediment samples collected at boreholes BF-MW-04 and BF-MW-07 included SWC, matric potential, and particle-size distribution (table 9). Volumetric SWC, assuming BD from the collocated soil core was 0.14 plus or minus $0.07 \mathrm{~m}^{3} / \mathrm{m}^{3}$, ranged from 0.05 to $0.39 \mathrm{~m}^{3} / \mathrm{m}^{3}$. Matric potential (pore-water pressure in absolute value) ranged from very dry $(2,400 \mathrm{~m})$ near the surface to nearly saturated $(0.01 \mathrm{~m})$ above impeding layers of sandy clay loam. Sediments generally were coarse grained with sand content ranging from 38 to 96 percent with a mean of 78 plus or minus 11 percent, whereas clay content ranged from 2 to 26 percent with a mean of 13 plus or minus 6 percent. The mean RPD for duplicates was less than 30 percent for all physical sediment parameters. 


\section{BF-MW-04}
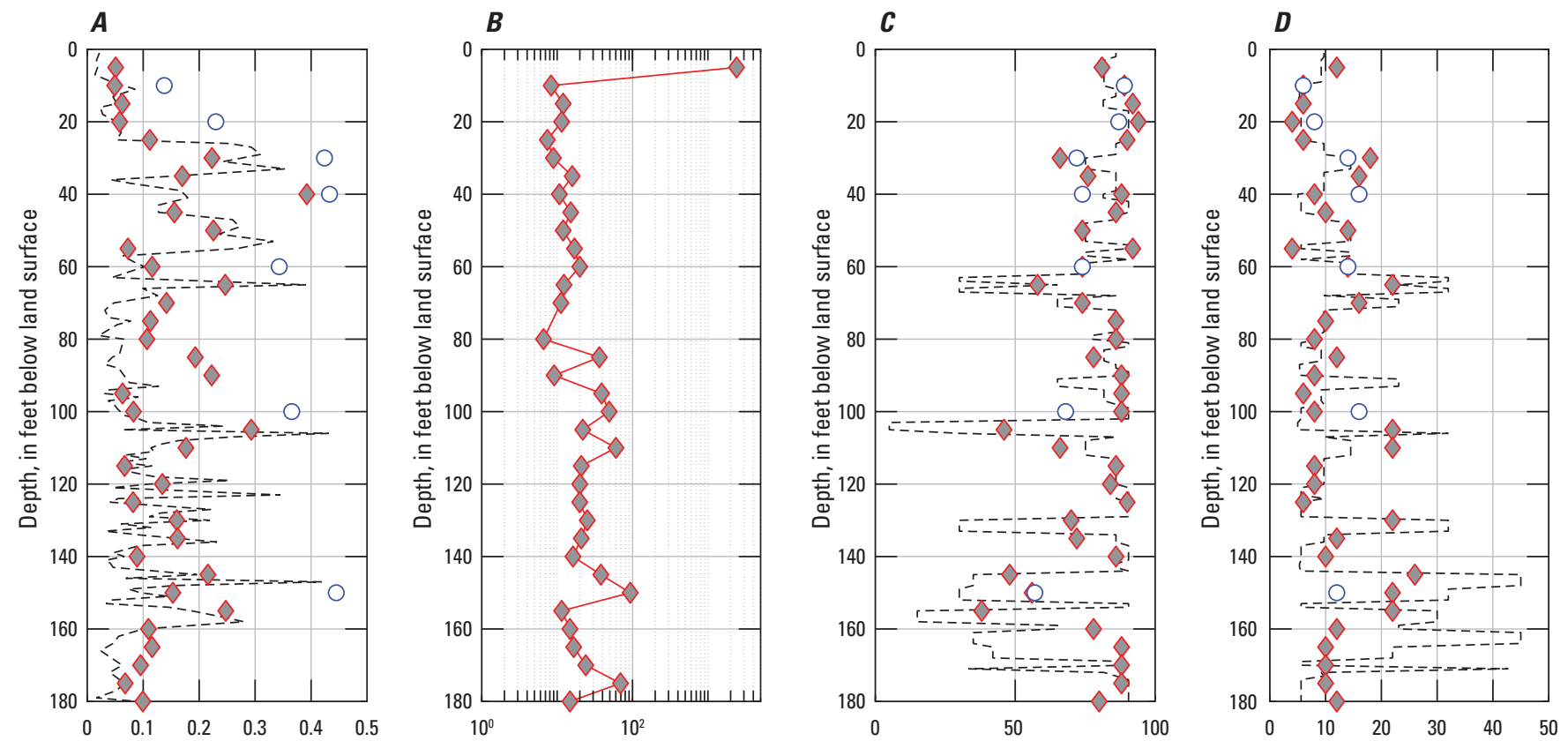

\section{BF-MW-07}
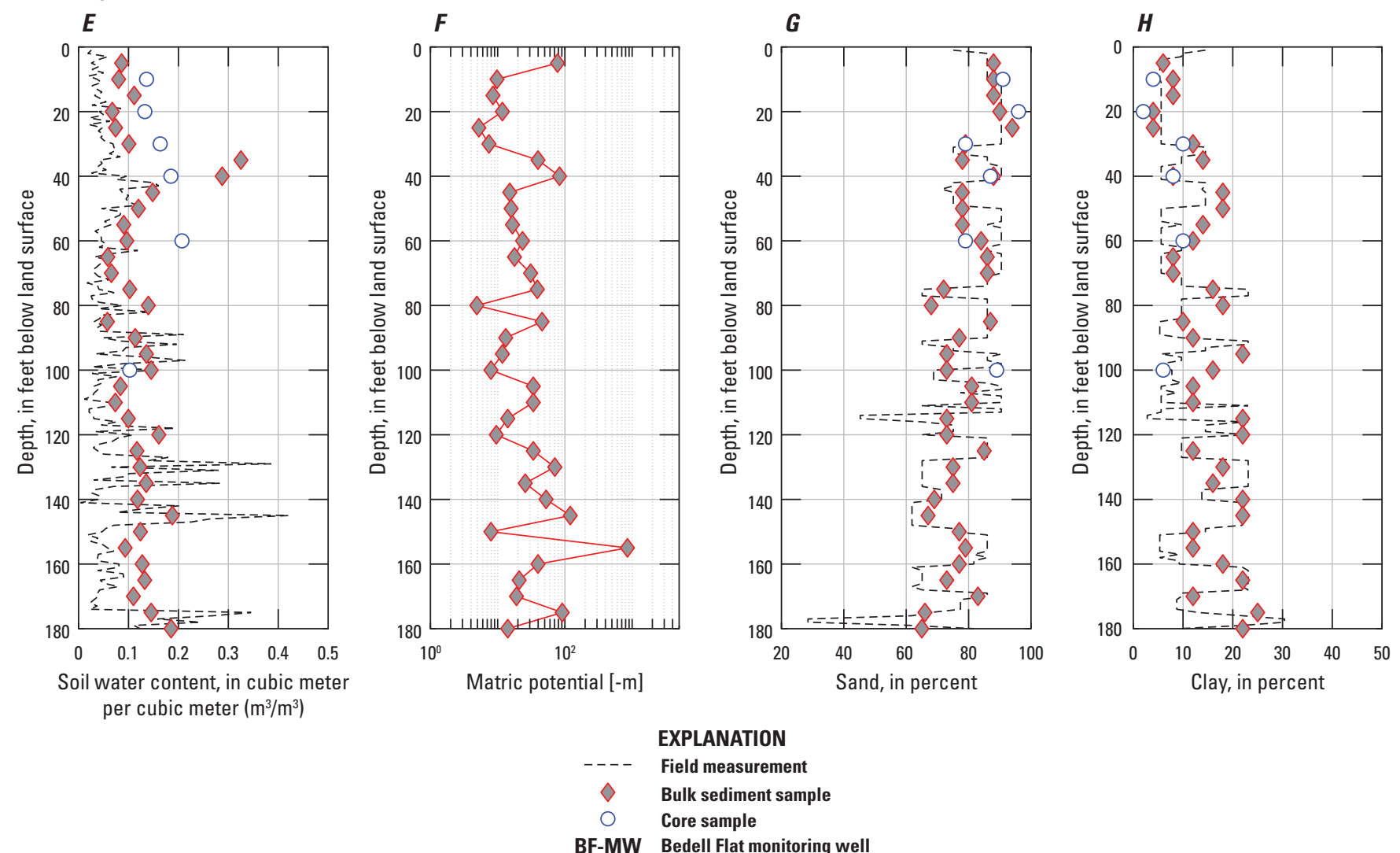

Figure 13. Physical characterization of the unsaturated zone from field measurements, bulk sediment samples, and core samples for $A$, soil water content (SWC), $B$, matric potential, $C$, sand, and $D$, clay at BF-MW-04 in the Bird Springs drainage; and $E$, SWC, $F$, matric potential, $G$, sand, and $H$, clay at BF-MW-07 in the Sand Hills drainage. 
Table 9. Summary statistics for bulk sediment analyses for BF-MW-04 and BF-MW-07 and mean relative percent difference (RPD) between laboratory duplicates.

$\left[\%\right.$, percent; SWC, soil water content; $\mathrm{m}^{3} / \mathrm{m}^{3}$, cubic meter per cubic meter; $-\mathrm{m}$, negative meters; EC, electrical conductivity; $\mathrm{dS} / \mathrm{m}$, deciSiemens per meter; $\mathrm{mg} / \mathrm{kg}$, milligrams per kilogram soil; $\mathrm{NO}_{3}-\mathrm{N}$, nitrate as nitrogen; $\mathrm{SO}_{4}-\mathrm{S}$, sulfate as sulfur; $\mathrm{Cl}$, chloride; - , no units; $\mathrm{CEC}$, cation exchange capacity; meq/100g, milliequivalents per 100 grams soil]

\begin{tabular}{lcccccc}
\hline \multicolumn{1}{c}{ Parameter } & Units & Mean & $\begin{array}{c}\text { Standard } \\
\text { deviation }\end{array}$ & Maximum & Minimum & $\begin{array}{c}\text { Mean RPD } \\
\text { (\%) }\end{array}$ \\
\hline SWC & $\mathrm{m}^{3} / \mathrm{m}^{3}$ & 0.139 & 0.070 & 0.392 & 0.049 & 9.1 \\
Matric potential & $-\mathrm{m}$ & 66.3 & 273 & 2,399 & 0.01 & 22.1 \\
Sand & Percent & 78 & 11 & 96 & 38 & 2.8 \\
Silt & Percent & 9 & 7 & 40 & 2 & 27.1 \\
$\mathrm{Clay}$ & Percent & 13 & 6 & 26 & 2 & 5.6 \\
$\mathrm{EC}$ & $\mathrm{dS} / \mathrm{m}$ & 0.2 & 0.1 & 0.4 & 0.1 & 8.3 \\
$\mathrm{NO}{ }_{3}-\mathrm{N}$ & $\mathrm{mg} / \mathrm{kg}$ & 1 & 1 & 8 & 1 & 32.7 \\
$\mathrm{SO}{ }_{4}-\mathrm{S}$ & $\mathrm{mg} / \mathrm{kg}$ & 2 & 1 & 7 & 1 & 21.7 \\
$\mathrm{Cl}$ & $\mathrm{mg} / \mathrm{kg}$ & 8 & 3 & 18 & 2 & 21.7 \\
Organic matter & $\mathrm{Percent}$ & 0.4 & 0.2 & 0.9 & 0.1 & 37.5 \\
$\mathrm{pH}$ & - & 7.5 & 0.4 & 8.4 & 6.5 & 1.2 \\
$\mathrm{CEC}$ & $\mathrm{meq} / 100 \mathrm{~g}$ & 7.4 & 3.2 & 17.3 & 2.8 & 5.1 \\
Sodium & $\mathrm{mg} / \mathrm{kg}$ & 42 & 20 & 118 & 17 & 4.7 \\
Potassium & $\mathrm{mg} / \mathrm{kg}$ & 80 & 45 & 254 & 16 & 6.7 \\
Calcium & $\mathrm{mg} / \mathrm{kg}$ & 1,029 & 437 & 2,388 & 425 & 5.4 \\
Magnesium & $\mathrm{mg} / \mathrm{kg}$ & 224 & 110 & 573 & 57 & 5.6 \\
\hline & & & & & &
\end{tabular}

\section{Borehole Geochemical Profiles}

Bulk sediments samples had low salinity (EC less than 0.1 deciSiemens per meter, $\mathrm{dS} / \mathrm{m}$ ) and anion content (less than $20 \mathrm{mg} / \mathrm{kg}$; table 9). Nitrate, as nitrogen, ranged from 1 to $8 \mathrm{mg} / \mathrm{kg}$, whereas sulfate as sulfur $\left(\mathrm{SO}_{4}-\mathrm{S}\right)$ ranged from 1 to $7 \mathrm{mg} / \mathrm{kg}$, and chloride ranged from 2 to $18 \mathrm{mg} / \mathrm{kg}$. Considering the mean sediment $\mathrm{pH}$ was slightly basic at 7.5 plus or minus 0.4 and calcium was the dominant cation, the remainder of the soluble anions are likely bicarbonates. The mean RPD was less than 30 percent for all geochemical analyses except $\mathrm{NO}_{3}-\mathrm{N}$ (32.7 percent) and organic matter (37.5 percent). If the RPD exceeded 30 percent, it does not necessarily mean the data are of poor quality, particularly at the low concentrations for $\mathrm{NO}_{3}-\mathrm{N}$ and organic matter (0.1-0.9 percent by weight).

Depth profiles from bulk sediment and core samples along with field EC and geochemical data also indicated perched zones of soil moisture residing atop of finer-textured, vertical impeding layers. Several higher salinty zones in field EC readings (approximately $0.5 \mathrm{dS} / \mathrm{m}$ ) were measured from 25 to $35,65,110,150$, and $160 \mathrm{ft}$ bls at BF-MW-04 (fig. 14A) and from 40 to 50, 130 to 150 , and $175 \mathrm{ft}$ bls at BF-MW-07 (fig. 14E). Laboratory EC results from the bulk sediments collected during roto-sonic boring and cores from traditional split spoon sampling did not indicate any zones of elevated pore-water concentrations in the unsaturated zone that could impact water quality.

Relic nitrate accumulation in the vadose zone of arid lands, including northern Nevada, can be considerable and pose a substantial risk to water quality in ASR operations. Pore-water concentrations in sediment 1-2 $\mathrm{m}$ bls can exceed $3,000 \mathrm{mg} / \mathrm{L}$ with nitrogen inventories ranging from 30 to $13,600 \mathrm{~kg}$ of nitrogen per hectare (N/ha; Walvoord and others, 2003). The U.S. Environmental Protection Agency drinking water standard for $\mathrm{NO}_{3}-\mathrm{N}$ is $10 \mathrm{mg} / \mathrm{L}$ (U.S. Environmental Protection Agency, 2009). In fact, TMWA operations in Spanish Springs, one valley east of Bedell Flat, have experienced substantial increases in groundwater $\mathrm{NO}_{3}-\mathrm{N}$ during the past 20 years (Menon and others, 2010). Integrating the $\mathrm{NO}_{3}-\mathrm{N}$ content with depth to the aquifer at $180 \mathrm{ft}$ bls, the nitrogen inventories at BF-MW-04 and BF-MW-07 were estimated at 4,270 and $2,436 \mathrm{~kg} \mathrm{~N} / \mathrm{ha}$, respectively, which is elevated but in mid-range of those reported by Walvoord and others (2003). 


\section{BF-MW-04}
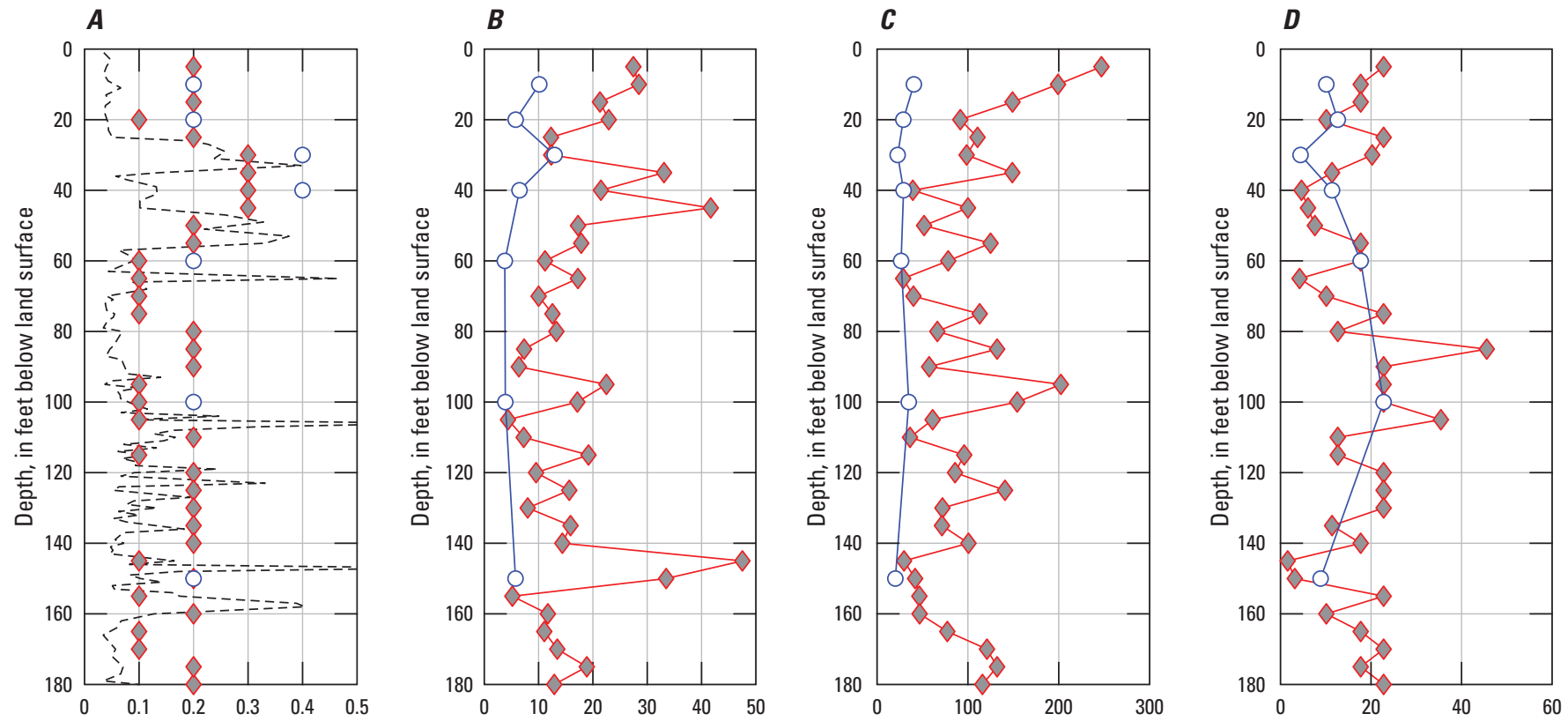

\section{BF-MW-07}
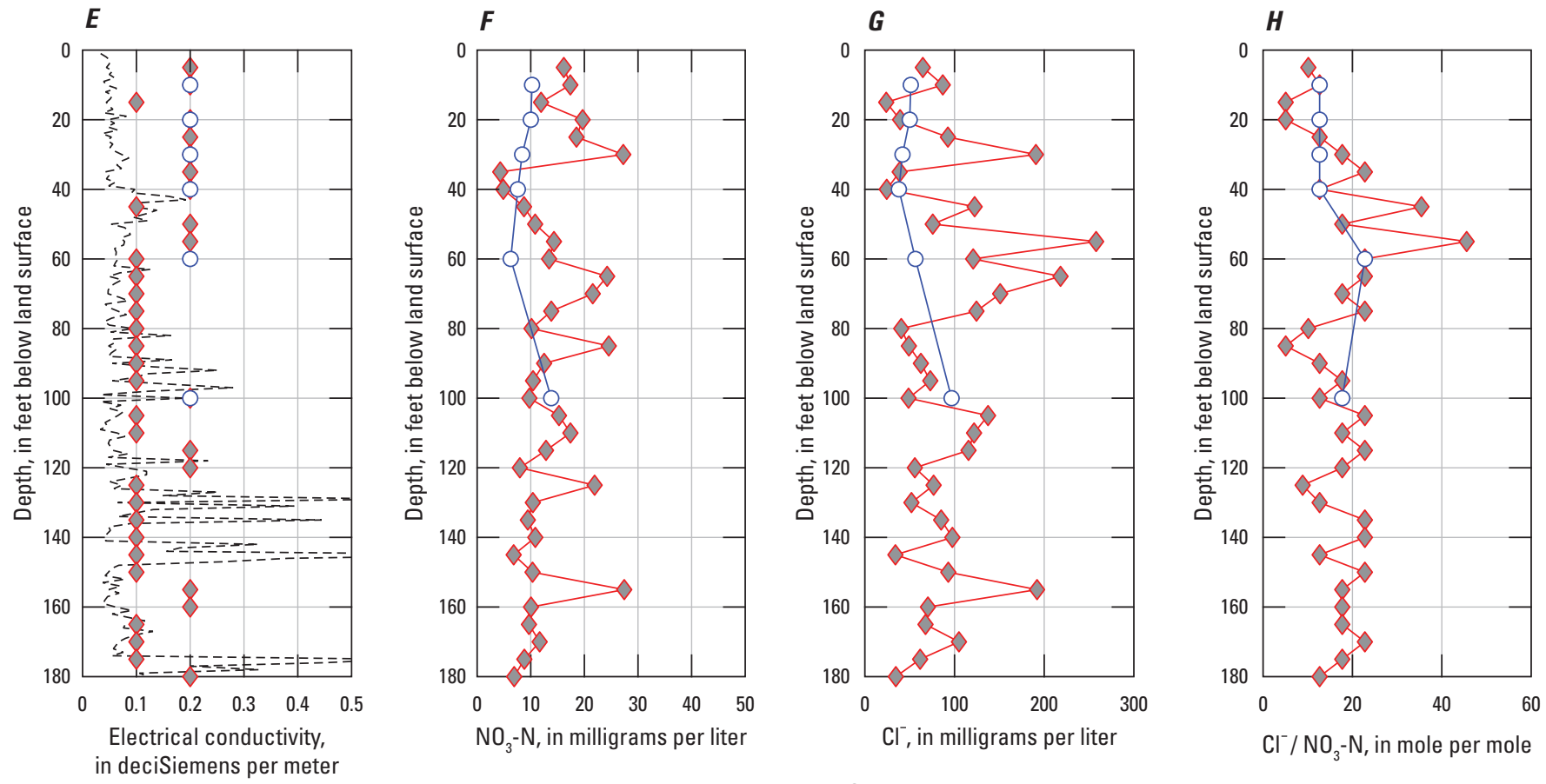

\section{EXPLANATION}

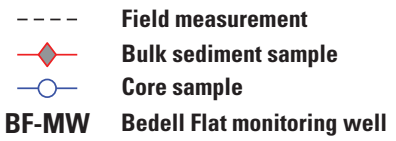

Figure 14. Geochemical characterization from field measurements, bulk sediment samples, and core samples for $A$, electrical conductivity $(\mathrm{EC}), B$, pore-water nitrate as nitrogen $\left(\mathrm{NO}_{3}-\mathrm{N}\right), C$, pore-water chloride $\left(\mathrm{Cl}^{-}\right)$, and $D$, molar ratios of $\mathrm{Cl}^{-}$to $\mathrm{NO}_{3}-\mathrm{N}$ at

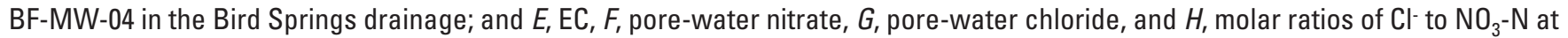
BF-MW-07 in the Sand Hills drainage. 
Soluble anions beneath vegetation (for example, sagebrush) of interfluvial areas in the southwestern United States are characterized by large amounts of accumulation immediately below the root zone, suggesting very low, if any, rates of modern recharge (Phillips, 1994; Stonestrom and others, 2003; Scanlon and others, 2009). These studies have observed peaks in anion concentrations at 2 to $5 \mathrm{~m}$ bls and occasionally secondary peaks deeper in the profile suggest periods of higher recharge during the wetter Pleistocene (McDonald and others, 1996; Tyler and others, 1996). For BF-MW-04 in Bird Springs, $\mathrm{NO}_{3}-\mathrm{N}$ has three noticeable accumulation peaks at 10 and $45 \mathrm{ft}$ bls with a substantial bulge from 140 to $160 \mathrm{ft}$ bls (fig. 14B). Accumulations for $\mathrm{Cl}^{-}$decrease with depth to $20 \mathrm{ft}$ bls with two additional peaks at 95 and $125 \mathrm{ft}$ bls (fig. 14C). For BF-MW-07 in Sand Hills, $\mathrm{NO}_{3}-\mathrm{N}$ has two noticeable accumulation peaks at 30 and $65 \mathrm{ft}$ bls (fig. 14F). Several accumulation zones for $\mathrm{Cl}^{-}$ were measured from 40 to 80,100 to 120 , and 145 to $160 \mathrm{ft}$ bls (fig. 14G). The large discrepancies between pore-water anion concentrations from bulk sediment and cores was primarily caused by large differences in SWC. The cores had considerably higher SWC than either field SWC measurements or bulk sediments, particularly at BF-MW-04 (fig. 13A) which dilutes the overall pore-water concentrations.

The correspondence between peaks in concentrations of $\mathrm{Cl}^{-}$and $\mathrm{NO}_{3}-\mathrm{N}$ at both boreholes was noticeable and consistent with evapo-concentration of conservative tracers within and below the root zone. Although $\mathrm{Cl}^{-}$and nitrogen originate primarily from atmospheric deposition, nitrogen can be utilized and transformed within the root zone as part of the biogeochemical cycle of nitrogen (Hartsough and others, 2001). However, once converted to inorganic $\mathrm{NO}_{3}-\mathrm{N}, \mathrm{Cl}^{-}$and $\mathrm{NO}_{3}-\mathrm{N}$ are essentially conservative tracers in the vadose zone and the molar ratio of $\mathrm{Cl}^{-}$to $\mathrm{NO}_{3}-\mathrm{N}$ should remain relatively constant with depth. Below the rooting zone, depths where the ratio departs from the mean indicate percolating water that experienced different climate, land use, and vegetation (Scanlon and others, 2009). The mean molar ratio for Bird Springs BF-MW-04 was 17.1 plus or minus 8.9 for bulk sediment samples and 12.6 plus or minus 6.0 for cores. Depth profiles from bulk samples indicate areas of enriched $\mathrm{Cl}^{-}$at 85 and $105 \mathrm{ft}$ bls, whereas enriched $\mathrm{NO}_{3}-\mathrm{N}$ is at $40-50 \mathrm{ft}$ bls and 145-150 ft bls at BF-MW-04 (fig. 14D). In Sand Hills at BF-MW-07, the mean $\mathrm{Cl}: \mathrm{NO}_{3}-\mathrm{N}$ molar ratio was 17.5 plus or minus 8.0 for bulk sediment samples and 15.1 plus or minus 4.2 for cores. Molar ratios were more consistent in Sand Hills but did show enriched $\mathrm{Cl}^{-}$from 45 to $75 \mathrm{ft}$ bls and depleted $\mathrm{Cl}^{-}$from 15 to 20 , and 80 to $85 \mathrm{ft}$ bls (figs. 14D, H). Without additional geochemical data (for example, stable isotopes), we can only assume the variability in molar ratios was related to different sourced waters from perched, perennial water tables.

\section{Comparison of Sediment Sample Collection Methods}

One concern that arose during the drilling phase was the representativeness of the roto-sonic borings to more traditional sampling methods. Roto-sonic boring had many advantages over traditional mud rotary drilling including overall speed, a small annulus of disturbance, no fluids needed, continuous casing, and continuous core return. In particular, roto-sonic drilling provided high-resolution borehole logging (appendix 2) and facies interpretations (appendix 3). However, friction from rotation and resonance heated the bit (and sediment) as it was driven into the substrate potentially altering the physical and chemical properties of the sediment samples.

The SWC measured in the field with a portable sensor was compared to 72 extruded bulk samples that also were measured for SWC and texture in the laboratory (table 10). Although significantly correlated (Pearson rank correlation coefficient, $R$, of 0.45 ; probability value, $p$, less than 0.001 ), SWC from the sensor differed with a RMSD of $0.089 \mathrm{~m}^{3} / \mathrm{m}^{3}$ and a mean bias error of $-0.030 \mathrm{~m}^{3} / \mathrm{m}^{3}$. This bias could be attributable to the factory calibration and a lack of temperature correction in the portable sensor (the extruded sediment was very warm). However, the correlation was significant making the sensor a useful field tool. Field ribbon tests and hand texturing also were significantly correlated ( $p$ less than 0.001 ) to hydrometer tests performed in the lab on bulk sediment samples for sand, silt, and clay content. For example, sand content has the highest RMSD (12.4 percent) but a $R$ of 0.76 . Given the speed and economy, the roto-sonic cores provided a continuous record of lithology that was potentially missed using discrete sampling.

Although field characterization of SWC and silt content correlated significantly ( $p$ less than 0.001 ) to discrete soil cores, the correlation was not significant for sand content ( $p$ equals 0.03 ) or clay content ( $p$ equals 0.30 ; table 10). The number of core samples ( $N$ equals 13 ) for texture and chemistry was more limited, making statistical comparison more challenging. Soil water content from field characterization and cores differed by $0.119 \mathrm{~m}^{3} / \mathrm{m}^{3}$ (RMSD) and was biased dry by $-0.08 \mathrm{~m}^{3} / \mathrm{m}^{3}$. Correlation between bulk sediment and core samples ( $N$ equals 13 ) was only significant ( $p$ less than 0.001) for sand content and silt content. The cores were taken from a very discrete, 6-in. layer, whereas field and bulk samples were more integrated over a length scale of feet. Thus, any discrepancy (that is, lack of correlation) might simply be slight differences in the sampling depth (for example, the lithologic changes are very abupt) and given the low statistical power of the tests ( $N$ equals 13 ), it was unlikely that roto-sonic dramatically changed the physical characteristics of bulk sediment samples. 
Correlation between ion content $(\mathrm{mg} / \mathrm{kg})$ was only significant ( $p$ less than 0.05 ) for $\mathrm{SO}_{4}-\mathrm{S}$, sodium, and calcium, whereas none of the pore-water concentrations $(\mathrm{mg} / \mathrm{L})$ were significantly correlated. Any difference in geochemical content and SWC between bulk sediment and cores is compounded

Table 10. Summary statistics for comparisons of physical properties between field measurements and bulk sediment samples at all eight monitoring wells, and physical and geochemical comparisons between field measurements, bulk sediment samples, and core samples BF-MW-04 and BF-MW-07.

[SWC, soil water content; $N$, number of samples; $R$, Pearson rank correlation coefficient; $p$-value, probability value; RMSD, root-mean square difference; MBE, mean bias error; $\mathrm{m}^{3} / \mathrm{m}^{3}$, cubic meters of water per cubic meter of soil; $\mathrm{NO}_{3}-\mathrm{N}$, nitrate as nitrogen; $\mathrm{mg} / \mathrm{L}$, milligram per liter; $\mathrm{Cl}^{-}$, chloride; $\mathrm{SO}_{4}-\mathrm{S}$, sulfate as sulfur; $\mathrm{mg} / \mathrm{kg}$, milligram per kilogram soil]

\begin{tabular}{|c|c|c|c|c|c|c|}
\hline Category & Units & $N$ & $\boldsymbol{R}$ & p-value & RMSD & MBE \\
\hline \multicolumn{7}{|c|}{ Physical property comparison } \\
\hline \multicolumn{7}{|c|}{ Field measurements to bulk sediment samples at all boreholes } \\
\hline SWC & $\mathrm{m}^{3} / \mathrm{m}^{3}$ & 71 & 0.45 & $9 \mathrm{E}-05$ & 0.089 & -0.03 \\
\hline Sand & Percent & 72 & 0.76 & $7 \mathrm{E}-15$ & 12.4 & -1.38 \\
\hline Silt & Percent & 72 & 0.71 & $3 \mathrm{E}-12$ & 9.8 & 1.12 \\
\hline Clay & Percent & 72 & 0.62 & 9E-09 & 6.8 & -1.88 \\
\hline \multicolumn{7}{|c|}{ Field measurements to core samples at BF-MW-04 and BF-MW-07 } \\
\hline SWC & $\mathrm{m}^{3} / \mathrm{m}^{3}$ & 43 & 0.51 & $5 \mathrm{E}-04$ & 0.119 & -0.080 \\
\hline Sand & Percent & 13 & 0.61 & 0.03 & 12.743 & -0.087 \\
\hline Silt & Percent & 13 & 0.86 & $1 \mathrm{E}-04$ & 5.182 & -2.280 \\
\hline Clay & Percent & 13 & 0.31 & 0.30 & 7.326 & -0.634 \\
\hline \multicolumn{7}{|c|}{$\begin{array}{l}\text { Bulk sediment samples to core samples at BF-MW-04 and } \\
\qquad \text { BF-MW-07 }\end{array}$} \\
\hline SWC & $\mathrm{m}^{3} / \mathrm{m}^{3}$ & 13 & 0.49 & 0.09 & 0.160 & -0.112 \\
\hline Sand & Percent & 13 & 0.66 & 0.01 & 8.810 & 1.15 \\
\hline Silt & Percent & 13 & 0.75 & $3 \mathrm{E}-03$ & 5.166 & -1.92 \\
\hline Clay & Percent & 13 & 0.40 & 0.18 & 5.463 & 1.08 \\
\hline
\end{tabular}

Bulk sediment samples to core samples at BF-MW-04 and BF-MW-07

\begin{tabular}{lccrlrc}
$\mathrm{NO}_{3}-\mathrm{N}$ & $\mathrm{mg} / \mathrm{L}$ & 13 & -0.17 & 0.59 & 13.8 & 10.5 \\
$\mathrm{Cl}^{-}$ & $\mathrm{mg} / \mathrm{L}$ & 13 & -0.01 & 0.96 & 81.2 & 53.2 \\
$\mathrm{SO}_{4}-\mathrm{S}$ & $\mathrm{mg} / \mathrm{L}$ & 13 & 0.23 & 0.46 & 24.6 & 14.79 \\
$\mathrm{NO}_{3}-\mathrm{N}$ & $\mathrm{mg} / \mathrm{kg}$ & 13 & 0.45 & 0.13 & 1.4 & 0.38 \\
$\mathrm{Cl}^{-}$ & $\mathrm{mg} / \mathrm{kg}$ & 13 & 0.35 & 0.24 & 3.9 & 1.15 \\
$\mathrm{SO}_{4}-\mathrm{S}$ & $\mathrm{mg} / \mathrm{kg}$ & 13 & 0.76 & $2 \mathrm{E}-03$ & 1.0 & 0.08 \\
Sodium & $\mathrm{mg} / \mathrm{kg}$ & 13 & 0.66 & 0.01 & 21.7 & -11.8 \\
Calcium & $\mathrm{mg} / \mathrm{kg}$ & 13 & 0.80 & $9 \mathrm{E}-04$ & 296 & -98.8 \\
\hline
\end{tabular}

in the calculation of pore-water concentration, where there was already little correlation between the two collection techniques noted above. In general, we cannot conclude there was impact of the roto-sonic drilling method on geochemical characteristics of the bulk sediment samples.

\section{Conceptual Recharge Model for the Bird Springs and Sand Hills Drainages}

The original conceptual model of Bedell Flat made it an ideal candidate for ASR - a deep, sandy, granitic basin at an elevation well above any lacustrine deposit related to pluvial Lake Lahontan. The conceptual model assumed substantial fluvial losses along Bird Springs channel that recharged the unconfined aquifer maintaining a modest hydraulic gradient toward the basin outflow at Tod Hunter Spring. The Bird Springs channel is poorly defined once it reaches the valley floor (fig. 2), indicating most runoff from the headwaters had fully infiltrated. Similarly, the channel in the Sand Hills drainage is essentially indiscernible in the field or even in 1-m lidar data (fig. 4). Under the extreme rainfall and runoff conditions experienced in WY 2017, Bird Springs channel caused major erosion along Bird Springs Road, particularly between boreholes BF-MW-02 and BF-MW-03, yet all runoff infiltrated into the sediment just beyond the BLM well (fig. 4). This conceptual model assumes limited or no perched layers that may inhibit downward infiltration, a relatively large storage capacity in the unsaturated zone and groundwater system, and an unconfined aquifer with minimal groundwater discharge or loss from Bedell Flat.

However, the updated conceptual model using hydrostratigraphic borehole data collected in this study shows a more complicated recharge pathway (fig. 15). The contrast in bedrock geology and channel incision into pediments creates more fines (silt and clay) in the Bird Springs drainage than in the Sand Hills drainage. Bird Springs is predominantly in granitic bedrock, which more easily weathers into coarse sands (quartz) and clay (feldspars). The upper channel is incised into late Quaternary pediments that contain more clay, and the stratigraphy is more heterogeneous. All three boreholes in the upper reaches of Bird Springs (BF-MW-01, -02, and -03) had impeding layer of silty material and $10 \mathrm{~s}$ of feet of perched soil moisture (approximately $0.30 \mathrm{~m}^{3} / \mathrm{m}^{3}$ ) at $40-60 \mathrm{ft}$ bls and a water table at $180 \mathrm{ft}$ bls (fig. 15A), although BF-MW-01 did not reach the saturated zone. When water table was reached, it was beneath thick finer-grained, dry material and water levels rose $10 \mathrm{ft}$ into the boreholes. Extensive vertical anisotropy in hydraulic conductivity is evident in the numerous fluctuations in silt and clay down each borehole. 


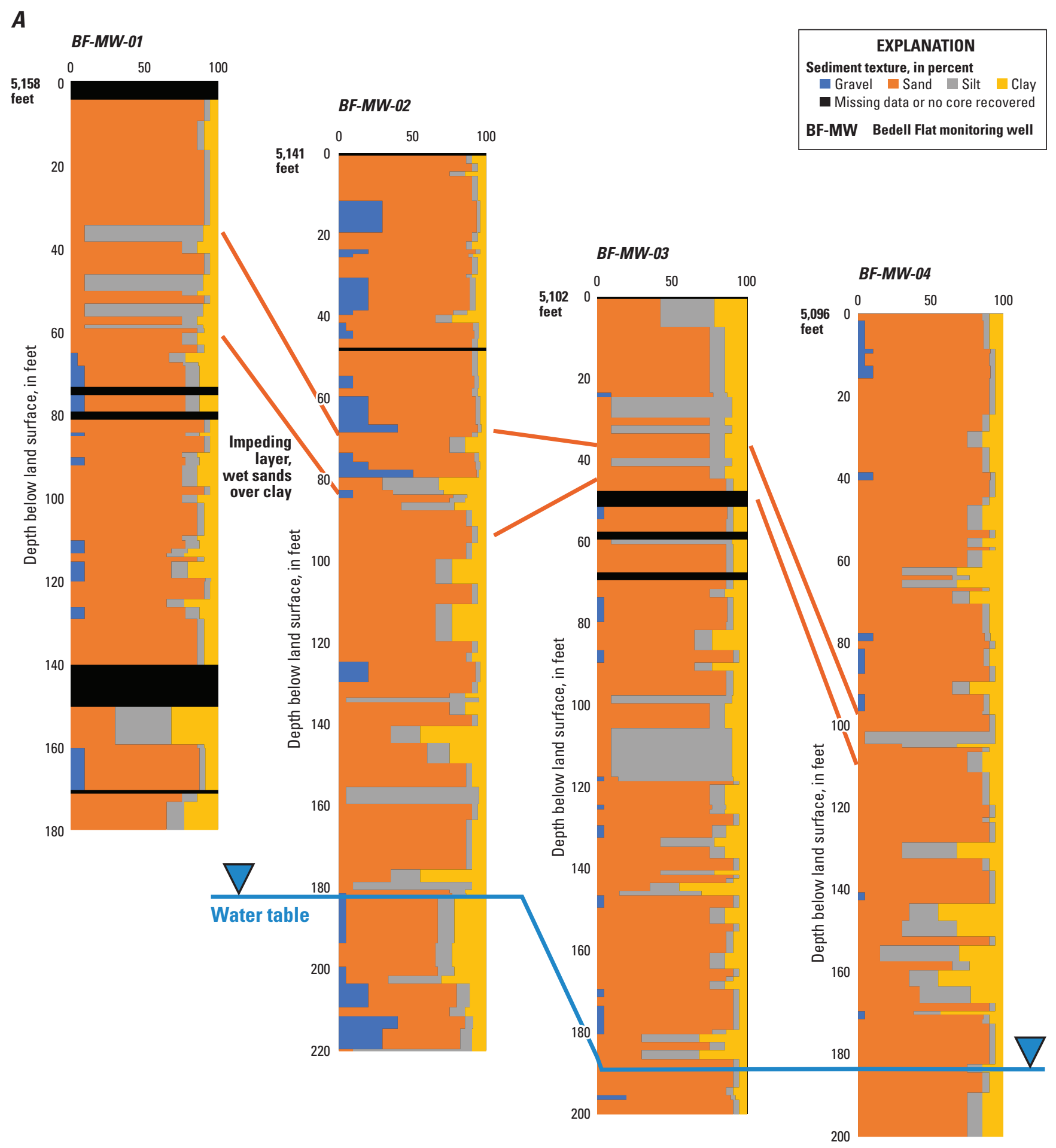

Figure 15. Compiled borehole lithologies corrected for elevation and the new conceptual recharge model for the $A$, Bird Springs and $B$, Sand Hills drainages. 


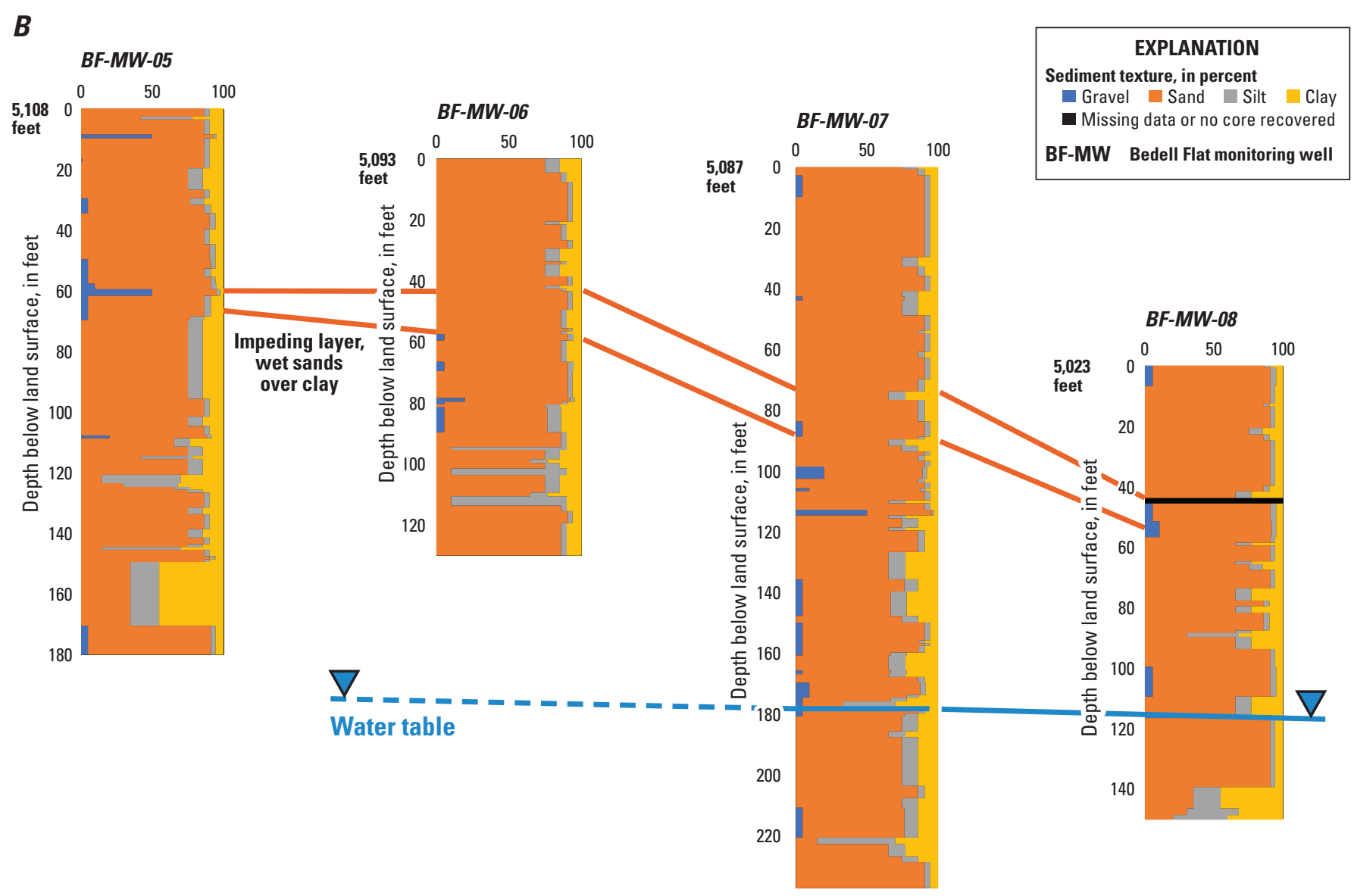

Figure 15.-Continued

The Sand Hills drainage, on the other hand, has no discernable channel because runoff completely infiltrates causing no surface expression from erosion. Various geomorphic events that mobilized sediment in both drainages contribute to the interbedded layers of thin clays and thick sands observed in the borehole logs. In the upper reaches of Sand Hill drainage, the impeding layers, 40-60 ft bls, were thinner (less than $10 \mathrm{ft}$ ) and perched soil moisture zone was also thinner (fig. 15B), reaching approximately $0.15 \mathrm{~m}^{3} / \mathrm{m}^{3}$ in BF-MW-07 (fig. 13E). The saturated zone was also beneath thick finer-grained, dry material, and under hydrostatic pressure. These fine-grained impeding layers also result in perched zones that are likely transmit more water laterally through coarser materials than vertically through the clays.

A RIB on such materials would infiltrate MAR through the surface sediments of either drainage; however, the trajectory of the water may be difficult to predict (O'Leary and others, 2012) and highly unlikely to enter the confined aquifer found at $180 \mathrm{ft}$ bls beneath a thick extensive layer of clay. The impeding clay layers thicken downgradient as the energy decreases, but highly transmissible sands still represent the majority of the sediment profile. While the continuity and slope are unknown, the trajectory of infiltrating water through these laterally transmissive sands from a point source on the surface (for example, RIB) would be analogous to a pachinko machine or plinco board, where an object cascades down a series of obstructions to some final random point at the bottom (for example, aquifer). This structure also makes it less likely that RIB water would propagate an immediate pressure response to the groundwater discharge area at Tod Hunter Spring, which is connected to the confined groundwater system recharged much higher in the drainage. The lateral continuity of the interbedded layers downgradient of this study area would need to be further investigated to assess the storage capacity of the vadose zone and any future impacts to groundwater discharge, and recovery from ASR in Bedell Flat. 


\section{Conclusions}

Bedell Flat is in the most western extent of the Great Basin Desert and the Basin and Range Province where high mountains discharge water down alluvial fans that terminate in ephemeral playa lakes. The Basin and Range is typified by extensional north trending faults with linear mountain ranges offset by normal faults forming structural depressions of thick sediments with alluvial aquifers in the basin fill. Bedell Flat is enclosed primarily by granodiorite mountains with an outcropping of sedimentary rocks that forms the Sand Hills. The predominate drainage in Bedell Flat is Bird Springs, which is incised into granitic rock and older pediments consisting of muddy sands. The Sand Hills drainage runs parallel, but the channel is poorly defined. The confluence of Bird Springs and Sand Hill channels is not visible suggesting any runoff generated has fully infiltrated just below the study area.

Results from seepage runs and model simulations indicate Bird Springs has sufficient capacity to infiltrate a large volume of water into the thick vadose zone beneath. Seepage losses measured and estimated from reaches and transects indicate substantial loss downgradient that is likely capable of supporting a continuous discharge of 2 million gallons per day for managed aquifer recharge. Borehole data suggest that while the unsaturated zone is predominantly coarse sands, thin interbedded layers of clay control the downward percolation of recharge. The sandstone parent material in the Sand Hills drainage had fewer impeding layers but the trajectory of recharge waters from a rapid infiltration basin operation in either drainage would be challenging to predict.

Bedell Flat was, and possibly remains, a candidate for in-channel managed aquifer recharge or rapid infiltration basin in Washoe County, Nevada, in the future. Understanding the extent and continuity of these impeding layers could be refined using geophysical techniques (for example, airborne electromagnetic surveys) or long-duration infiltration tests near boreholes. Surface rapid infiltration basin operations are unlikely to enter the aquifer system confined system given the extensive heterogeneous, layered structure of impeding, fine-grained sediments. If water moves laterally along more permeable sands, it may create a new unconfined aquifer atop and disconnected from the confined system. The storage capacity and recoverability of MAR water would need further investigation.

\section{References Cited}

Abatzoglou, J.T., 2013, Development of gridded surface meteorological data for ecological applications and modelling: International Journal of Climatology, v. 33, no. 1, p. 121-131, https://doi.org/10.1002/joc.3413.

Adams, K.D., and Wesnousky, S.G., 1998, Shoreline processes and the age of the Lake Lahontan highstand in the Jessup embayment, Nevada: Geological Society of America Bulletin, v. 110, no. 10, p. 1318-1332, https://doi.org/10.1130/0016-7606(1998)110\%3C1 318:SPATAO\%3E2.3.CO;2.

Andres, A.S., and Sims, J.T., 2013, Assessing potential impacts of a wastewater rapid infiltration basin system on groundwater quality - A Delaware case study: Journal of Environmental Quality, v. 42, no. 2, p. 391-404, https://doi.org/10.2134/jeq2012.0273.

Barrow, J.C., 1994, The resonant sonic drilling method-An innovative technology for environmental restoration programs: Ground Water Monitoring and Remediation, v. 14, no. 2, p. 153-160, https://doi.org/10.1111/j.1745-6592.1994.tb00110.x.

Berger, D.L., Ponce, D.A., and Ross, W.C., 2001, Hydrogeologic framework of Antelope Valley and Bedell Flat, Washoe County, west-central Nevada: U.S. Geological Survey Water Resources Investigation Report 2001-4220, 11 p., https://doi.org/10.3133/wri014220.

Bouwer, H., 2002, Artificial recharge of groundwater-Hydrogeology and engineering: Hydrogeology Journal, v. 10, p. 121-142, https://doi.org/10.1007/s10040-001-0182-4.

Bouwer, H., Back, J.T., and Oliver, J.M., 1999, Predicting infiltration and ground-water mounds for artificial recharge: Journal of Hydrologic Engineering, v. 4, no. 4, p. 350-357, https://doi.org/10.1061/(ASCE)1084-0699(1999)4:4(350).

Bouwer, H., and Rice, R.C., 1984, Renovation of wastewater at the 23rd Avenue rapid infiltration project: Water Pollution Control Federation, v. 56, p. 76-83.

Caldwell, T.G., Bongiovanni, T., Cosh, M.H., Halley, C., and Young, M.H., 2018, Field and laboratory evaluation of the CS655 soil water content sensor: Vadose Zone Journal, v. 17, no. 1, p. 1-16, https://doi.org/10.2136/vzj2017.12.0214. 
Carsel, R.F., and Parrish, R.S., 1988, Developing joint probability distributions of soil water retention characteristics: Water Resources Research, v. 24, no. 5, p. 755-769, https://doi.org/10.1029/WR024i005p00755.

Chapin, T.P., Todd, A.S., and Zeigler, M.P., 2014, Robust, low-cost data loggers for stream temperature, flow intermittency, and relative conductivity monitoring: Water Resources Research, v. 50, no. 8, p. 6542-6548, https://doi.org/10.1002/2013WR015158.

Chow, V.T., 1959, Open-channel hydraulics: New York, N.Y., McGraw-Hill, 680 p.

Constantz, J., 2008, Heat as a tracer to determine streambed water exchanges: Water Resources Research, v. 44, no. 4, 20 p., https://doi.org/10.1029/2008WR006996.

Dillon, P., 2005, Future management of aquifer recharge: Hydrogeology Journal, v. 13, p. 313-316, https://doi.org/10.1007/s10040-004-0413-6.

Dillon, P., Stuyfzand, P., Grischek, T., Lluria, M., Pyne, R.D.G., Jain, R.C., Bear, J., Schwarz, J., Wang, W., Fernandez, E., Stefan, C., Pettenati, M., van der Gun, J., Sprenger, C., Massmann, G., Scanlon, B.R., Xanke, J., Jokela, P., Zheng, Y., Rossetto, R., Shamrukh, M., Pavelic, P., Murray, E., Ross, A., Bonilla Valverde, J.P., Palma Nava, A., Ansems, N., Posavec, K., Ha, K., Martin, R., and Sapiano, M., 2019, Sixty years of global progress in managed aquifer recharge: Hydrogeology Journal, v. 27, no. 1, p. 1-30, https://doi.org/10.1007/s10040-018-1841-z.

Fetter, C.W., and Holzmacher, R.G., 1974, Groundwater recharge with treated wastewater: Water Pollution Control Federation, v. 46, no. 2, p. 260-270.

Gardner, W.H., 1986, Water content, chap. 21 of Klute, A., ed., Methods of soil analysis-Part 1 physical and mineralogical methods ( $2 \mathrm{~d}$ ed.): Madison, WI, SSSA Book Series, p. 493-544, https://doi.org/10.2136/sssabookser5.1.2ed.c21.

Garside, L.G., 1993, Geologic map of the Bedell Flat quadrangle, Nevada: Nevada Bureau of Mines and Geology, 1:24,000 7.5-minute quadrangle, FS003.

Gee, G.W., Campbell, M.D., Campbell, G.S., and Campbell, J.H., 1992, Rapid measurement of low soil-water potentials using a water activity meter: Soil Science Society of America Journal, v. 56, no. 4, p. 1068-1070, https://doi.org/10.2136/sssaj1992.03615995005 600040010x.

GeoSystems Analysis, 2019, Bedell Flat managed aquifer recharge prefeasibility report: Report to Truckee Meadows Water Authority, $28 \mathrm{p}$.
Grossman, R.B., and Reinsch, T.G., 2002, Bulk density and linear extensibility, in Dane, J.H., and Topp, G.C., eds., Methods of soil analysis, part 4-Physical Methods: Madison, Soil Science Society of America, p. 201-228, https://doi.org/10.2136/sssabookser5.4.c9.

Hartsough, P., Tyler, S.W., Sterling, J., and Walvoord, M., 2001, A $14.6 \mathrm{kyr}$ record of nitrogen flux from desert soil profiles as inferred from vadose zone pore waters: Geophysical Research Letters, v. 28, no. 15, p. 2955-2958, https://doi.org/10.1029/2000GL011823.

Healy, R.W., and Ronan, A.D., 1996, Documentation of computer program VS2DH for simulation of energy transport in variably saturated porous media-Modification of the U.S. Geological Survey's computer program VS2DT: U.S. Geological Survey Water-Resources Investigations Report 96-4230, 36 p., https://doi.org/10.3133/wri964230.

Henry, C.D., Ramelli, A.R., and Faulds, J.E., 2009, Geologic map of the Seven Lakes Mountain quadrangle, Washoe County, Nevada and the eastern part of the Constantia quadrangle, Lassen County, California: Nevada Bureau of Mines and Geology Map 164, 27 p., https://pubs.nbmg.unr.edu/Geologic-Seven-Lakes-Mtnquad-p/m164.htm.

Homer, C., Dewitz, J., Jin, S., Xian, G., Costello, C., Danielson, P., Gass, L., Funk, M., Wickham, J., Stehman, S., Auch, R., and Riitters, K., 2020, Conterminous United States land cover change patterns 2001-2016 from the 2016 National Land Cover Database: ISPRS Journal of Photogrammetry and Remote Sensing, v. 162, p. 184-199, https://doi.org/10.1016/j.isprsjprs.2020.02.019.

Hsieh, P.A., Wingle, W.L., and Healy, R.W., 2000, VS2DI-A graphical software package for simulating fluid flow and solute or energy transport in variably saturated porous media: U.S. Geological Survey Water-Resources Investigations Report 99-4130, 16 p., https://doi.org/10.3133/wri994130.

Kropf, C., White, N., and Pohll, G., 2020, Bedell Flat hydrogeologic investigation and groundwater recharge feasibility report: Truckee Meadows Water Authority, 16 p., https://tmwa.com/wp-content/uploads/2020/11/BedellFinal-Report-w-Appendix-05072020-FINAL.pdf.

Maples, S.R., Fogg, G.E., and Maxwell, R.M., 2019, Modeling managed aquifer recharge processes in a highly heterogeneous, semi-confined aquifer system: Hydrogeology Journal, v. 27, p. 2869-2888, https://doi.org/10.1007/s10040-019-02033-9. 
McDonald, E.V., Pierson, F.B., Flerchinger, G.N., and McFadden, L.D., 1996, Application of a soil-water balance model to evaluate the influence of Holocene climate change on calcic soils, Mojave Desert, California, USA: Geoderma, v. 74, no. 3-4, p. 167-192, https://doi.org/10.1016/S0016-7061(96)00070-5.

Menon, M., Parratt, R.T., Kropf, C.A., and Tyler, S.W., 2010, Factors contributing to nitrate accumulation in mesic desert vadose zones in Spanish Springs Valley, Nevada (USA): Journal of Arid Environments, v. 74, no. 9, p. 1033-1040, https://doi.org/10.1016/j.jaridenv.2010.03.005.

Miller, R.O., Gavlak, R.G., and Horneck, D.A., 2013, Soil, plant, and water reference methods for the Western Region (4th ed.): North American Proficiency Testing Program WREP-125, 155 p., https://www.naptprogram.org/files/ napt/publications/method-papers/western-states-methodsmanual-2013.pdf.

Moffet, C.A., Hardegree, S.P., Abatzoglou, J.T., Hegewisch, K.C., Reuter, R.R., Sheley, R.L., Brunson, M.W., Flerchinger, G.N., and Boehm, A.R., 2019, Weather tools for retrospective assessment of restoration outcomes: Rangeland Ecology and Management, v. 72, no. 2, p. 225-229, https://doi.org/10.1016/j.rama.2018.10.011.

Naranjo, R.C., 2019, Methods for installation, removal, and downloading data from the temperature profiling probe (TROD): U.S. Geological Survey Open-File Report 2019-1066, 14 p., https://doi.org/10.3133/ofr20191066.

Naranjo, R.C., and Smith, D.W., 2016, Quantifying seepage using heat as a tracer in selected irrigation canals, Walker River Basin, Nevada, 2012 and 2013: U. S. Geological Survey Scientific Investigations Report 2016-5133, 169 p., https://doi.org/10.3133/sir20165133.

Naranjo, R.C., Smith, D.W., and Caldwell, T.G., 2021, Documentation of VS2DH seepage models-Surface infiltration and unsaturated zone characterization in support of managed aquifer recharge, Washoe County, Nevada: U.S. Geological Survey data release, https://doi.org/10.5066/P9U9Q5PC.

Naranjo, R.C., and Turcotte, R., 2015, A new temperature profiling probe for investigating groundwater-surface water interaction: Water Resources Research, v. 51, no. 9, p. 7790-7797, https://doi.org/10.1002/2015WR017574.

Nawikas, J.M., O'Leary, D.R., Izbicki, J.A., and Burgess, M.K., 2016, Selected techniques for monitoring water movement through unsaturated alluvium during managed aquifer recharge: U.S. Geological Survey Open-File Report 2016-1180, 8 p., https://doi.org/10.3133/ofr20161180.
Niswonger, R.G., and Prudic, D.E., 2003, Modeling heat as a tracer to estimate streambed seepage and hydraulic conductivity, appendix B in Stonestrom, D.A., and Constantz, J., eds., Heat as a tool for studying the movement of ground water near streams: U.S. Geological Survey Circular 1260, p. 81-89, https://doi.org/10.3133/cir1260.

O’Leary, D.R., Izbicki, J.A., Moran, J.E., Meeth, T., Nakagawa, B., Metzger, L., Bonds, C., and Singleton, M.J., 2012, Movement of water infiltrated from a recharge basin to wells: Ground Water, v. 50, no. 2, p. 242-255, https://doi.org/10.1111/j.1745-6584.2011.00838.x.

Peterson, F.F., 1981, Landforms of the basin and range province-Defined for soil survey: Reno, Nev., Nevada Agricultural Experiment Station, University of Nevada, Reno Technical Bulletin 28, 52 p., https://www.ars.usda.gov/ARSUserFiles/30501000/esd/ pubs/Peterson_LandformsBasinRangeProvince.pdf.

Phillips, F.M., 1994, Environmental tracers for water-movement in desert soils of the American southwest: Soil Science Society of America Journal, v. 58, no. 1, p. 15-24, https://doi.org/10.2136/sssaj1994.03615995005 800010003x.

Raines, G.L., Connors, K.A., Moyer, L.A., and Miller, R.J., 2003, Spatial digital database for the geologic map of Nevada: U.S. Geological Survey Open File Report 2003-66, https://doi.org/10.3133/ofr0366.

Rosenberry, D.O., and LaBaugh, J.W., 2008, Field techniques for estimating water fluxes between surface water and ground water: U.S. Geological Survey Techniques and Methods 4-D2, 135 p., https://doi.org/10.3133/tm4D2.

Rush, F.E., and Glancy, P.A., 1967, Water-resources appraisal of the Warm Springs-Lemmon Valley Area, Washoe County, Nevada: U.S. Department of the Interior, Geological Survey, 70 p., http://images.water.nv.gov/images/publications/ recon\%20reports/rpt43-warm_springs_lemmon_valley.pdf.

Rydlund, P.H., Jr., and Densmore, B.K., 2012, Methods of practice and guidelines for using survey-grade global navigation satellite systems (GNSS) to establish vertical datum in the United States Geological Survey: U.S. Geological Survey Techniques and Methods, book 11, chap. D1, 102 p., with appendixes, https://doi.org/10.3133/tm11D1.

Scanlon, B.R., Stonestrom, D.A., Reedy, R.C., Leaney, F.W., Gates, J., and Cresswell, R.G., 2009, Inventories and mobilization of unsaturated zone sulfate, fluoride, and chloride related to land use change in semiarid regions, southwestern United States and Australia: Water Resources Research, v. 45, no. 7, 17 p., https://doi.org/10.1029/2008WR006963. 
Sharma, S.K., and Kennedy, M.D., 2017, Soil aquifer treatment for wastewater treatment and reuse: International Biodeterioration \& Biodegradation, v. 119, p. 671-677, https://doi.org/10.1016/j.ibiod.2016.09.013.

Sheng, Z., 2005, An aquifer storage and recovery system with reclaimed wastewater to preserve native groundwater resources in El Paso, Texas: Journal of Environmental Management, v. 75, no. 4, p. 367-377, https://doi.org/10.1016/j.jenvman.2004.10.007.

Smith, D.W., Naranjo, R.C., Caldwell, T.G., and O'Connor, K.E., 2021, Supplemental data- Surface infiltration and unsaturated zone characterization in support of managed aquifer recharge, Bedell Flat, Washoe County, Nevada: U.S. Geological Survey data release, https://doi.org/10.5066/P9OAF8L8.

Soil Science Division Staff, 2017, Soil survey manual, in Ditzler, C., Scheffe, K., and Monger, H.C., eds., USDA Handbook 18: Washington, D.C., Government Printing Office, 603 p., https://www.nrcs.usda.gov/wps/portal/nrcs/ detail/soils/scientists/?cid=nrcs142p2_054262.

Standen, K., Costa, L.R.D., and Monteiro, J.-P., 2020, In-channel managed aquifer recharge- $\mathrm{A}$ review of current development worldwide and future potential in Europe: Water, v. 12, no. 11, p. 3099, https://doi.org/10.3390/w12113099.

Stonestrom, D.A., Prudic, D.E., Laczniak, R.J., Akstin, K.C., Boyd, R.A., and Henkelman, K.K., 2003, Estimates of deep percolation beneath native vegetation, irrigated fields, and the Amargosa-River channel, Amargosa Desert, Nye County, Nevada: U.S. Geological Survey Open-File Report 2003-104, 88 p., https://doi.org/10.3133/ofr03104.

Thien, S.J., 1979, A flow diagram for teaching texture-by-feel analysis: Journal of Agronomic Education, v. 8, no. 1, p. 54-55, https://doi.org/10.2134/jae.1979.0054.
Turnipseed, D.P., and Sauer, V.B., 2010, Discharge measurements at gaging stations: U.S. Geological Survey Techniques and Methods 3-A8, 87 p., https://doi.org/10.3133/tm3A8.

Tyler, S.W., Chapman, J.B., Conrad, S.H., Hammermeister, D.P., Blout, D.O., Miller, J.J., Sully, M.J., and Ginanni, J.M., 1996, Soil-water flux in the southern Great Basin, United States-Temporal and spatial variations over the last 120,000 years: Water Resources Research, v. 32, no. 6, p. 1481-1499, https://doi.org/10.1029/96WR00564.

U.S. Environmental Protection Agency, 2009, National primary drinking water regulations table: U.S. Environmental Protection Agency EPA 816-F-09-004, 7 p., https://www.nrc.gov/docs/ML1307/ML13078A040.pdf.

Walvoord, M.A., Phillips, F.M., Stonestrom, D.A., Evans, R.D., Hartsough, P.C., Newman, B.D., and Striegl, R.G., 2003, A reservoir of nitrate beneath desert soils: Science, v. 302, no. 5647, p. 1021-1024, https://doi.org/10.1126/science.1086435.

Welter, D.E., White, J.T., Hunt, R.J., and Doherty, J.E., 2015, Approaches in highly parameterized inversion-PEST++ Version 3, a Parameter ESTimation and uncertainty analysis software suite optimized for large environmental models: U.S. Geological Survey Techniques and Methods 7-C12, 11 p., https://doi.org/10.3133/tm7C12.

Yang, L., Jin, S., Danielson, P., Homer, C., Gass, L., Bender, S.M., Case, A., Costello, C., Dewitz, J., Fry, J., Funk, M., Granneman, B., Liknes, G.C., Rigge, M., and Xian, G., 2018, A new generation of the United States National Land Cover Database-Requirements, research priorities, design, and implementation strategies: ISPRS Journal of Photogrammetry and Remote Sensing, v. 146, p. 108-123, https://doi.org/10.1016/j.isprsjprs.2018.09.006. 


\section{Appendix 1. Measured and Simulated Thermographs for Channel Sediments}

\section{Transect 2}
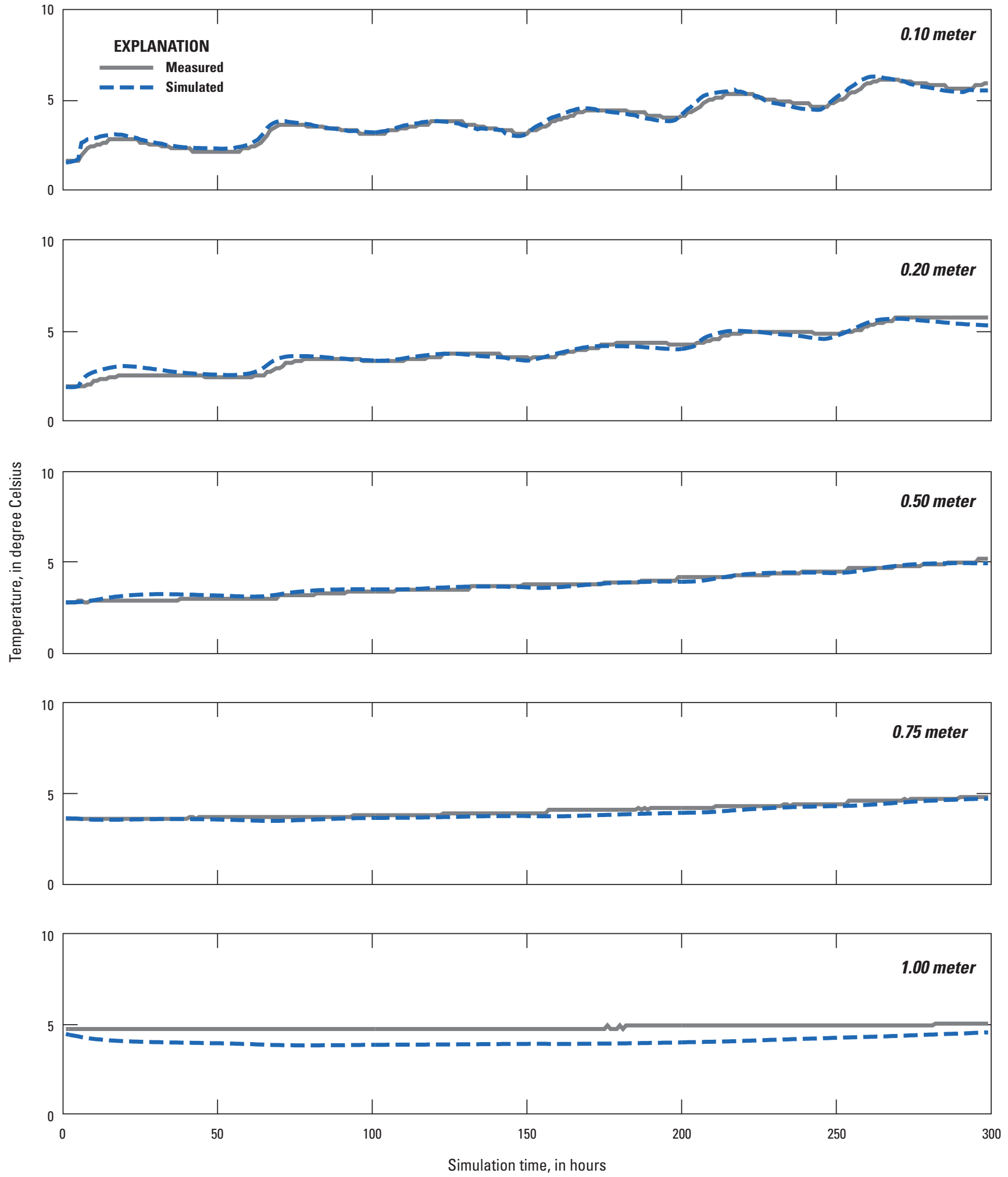

Figure 1.1. Subsurface temperatures observed and simulated at Transect 2 for depths $0.10,0.20,0.50,0.75$, and 1.00 meter below land surface during the calibration period from March 8, 2017, 9:30 a.m. to March 14, 2017, 2:30 p.m. 


\section{Transect 3}
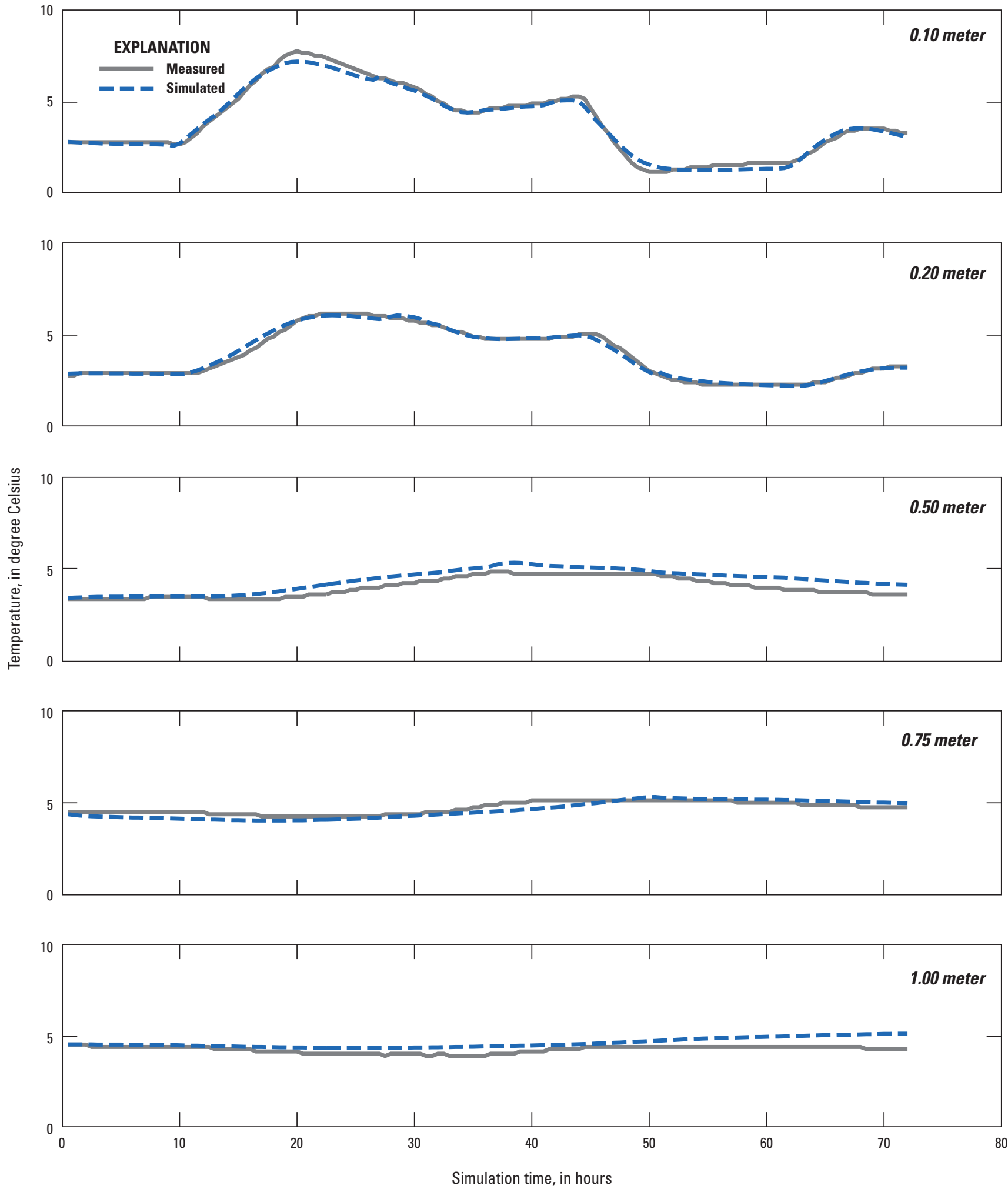

Figure 1.2. Subsurface temperatures observed and simulated at Transect 3 for depths $0.10,0.20,0.50,0.75$, and 1.00 meter below land surface during the calibration period from March 21, 2018, 12:00 a.m. to March 23, 2018, 11:30 p.m. 


\section{Transect 4}
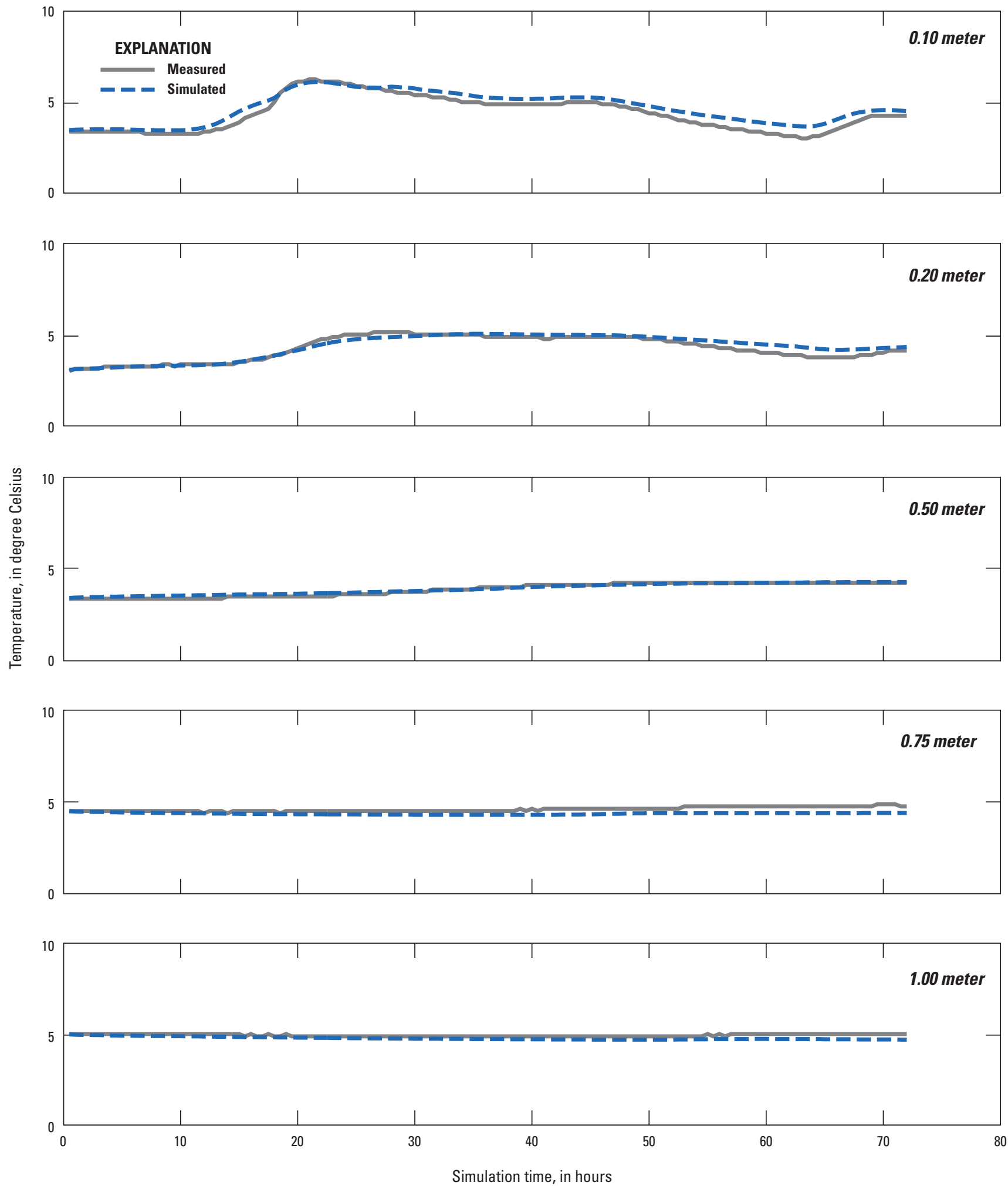

Figure 1.3. Subsurface temperatures observed and simulated at Transect 4 for depths $0.10,0.20,0.50,0.75$, and 1.00 meter below land surface during the calibration period from March 21, 2018, 12:00 a.m. to March 23, 2018, 11:30 p.m. 


\section{Transect 5}
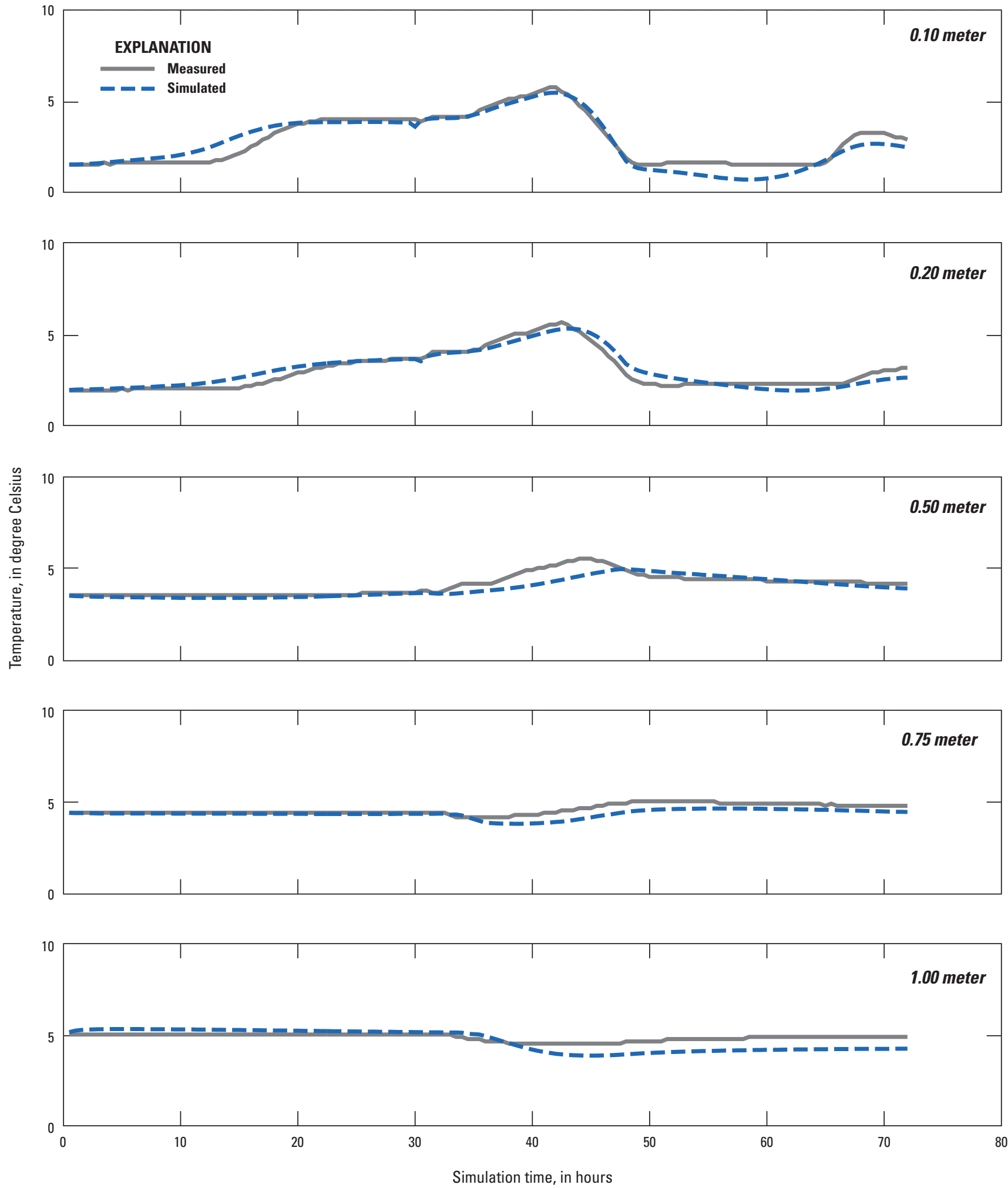

Figure 1.4. Subsurface temperatures observed and simulated at Transect 5 for depths $0.10,0.20,0.50,0.75$, and 1.00 meter below land surface during the calibration period from March 21, 2018, 12:00 a.m. to March 23, 2018, 11:30 p.m. 


\section{Transect 6}
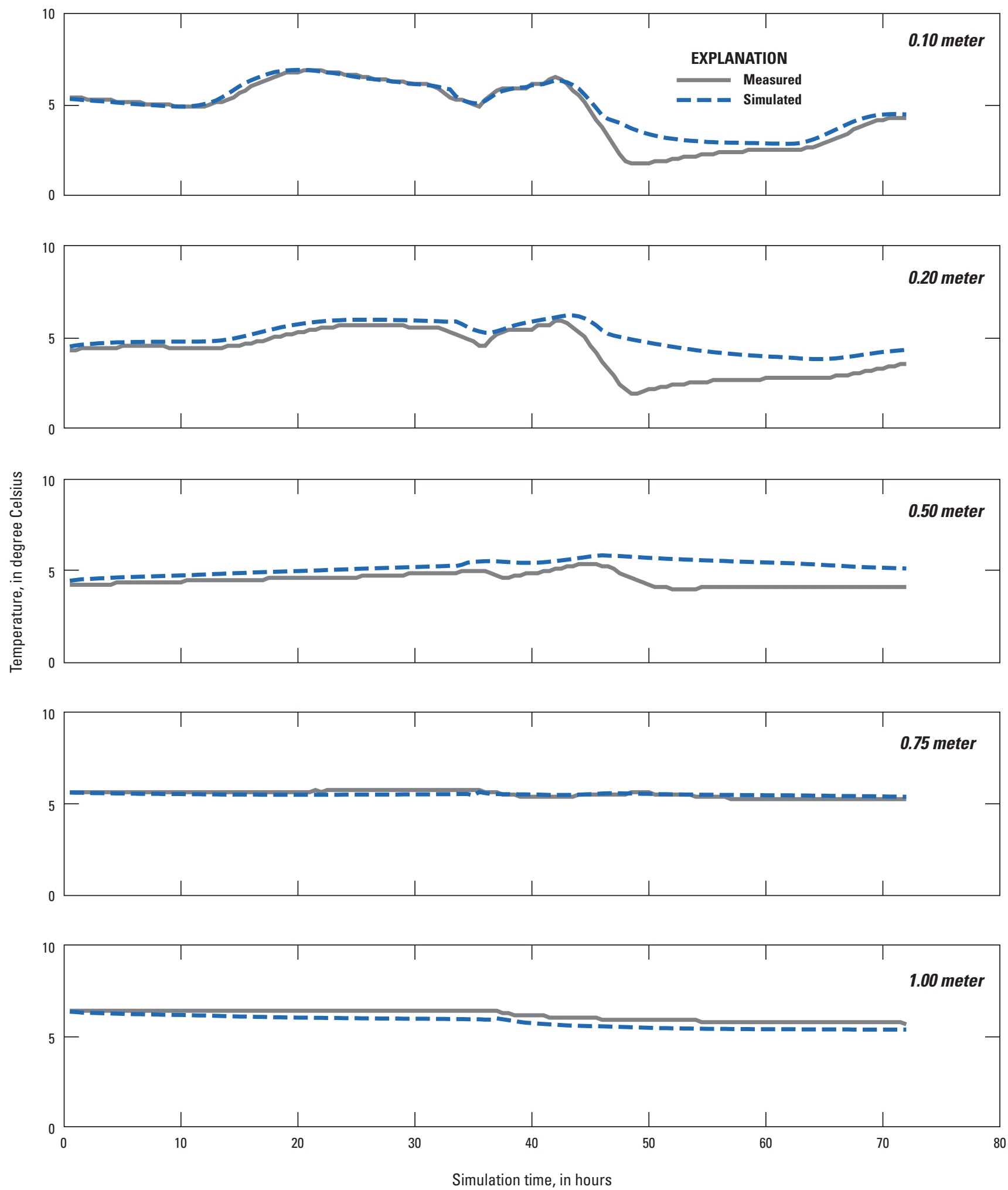

Figure 1.5. Subsurface temperatures observed and simulated at Transect 6 for depths $0.10,0.20,0.50,0.75$, and 1.00 meter below land surface during the calibration period from March 21, 2018, 12:00 a.m. to March 23, 2018, 11:30 p.m. 


\section{Appendix 2. Borehole Characterization Data}

Table 2.1. Soil moisture, texture, and geochemical composition of water extracts from bulk sediment samples at BF-MW-04.

[ft bls, feet below land surface; SWC, soil water content; g/g, grams per gram; MP, matric potential; -m, negative meters of water; EC, electrical conductivity; $\mathrm{dS} / \mathrm{m}$, deciSiemens per meter; $\mathrm{Cl}$, chloride; $\mathrm{mg} / \mathrm{kg}$, milligrams per kilogram; $\mathrm{NO}_{3}-\mathrm{N}$, nitrate as nitrogen; $\mathrm{SO}_{4}-\mathrm{S}$, sulfate as sulfur; $\mathrm{K}$, potassium; $\mathrm{Mg}$, magnesium; $\mathrm{Ca}$, calcium; $\mathrm{Na}$, sodium; OM, organic material; \%, percent; $\mathrm{D}$, duplicate analysis; - , no data]

\begin{tabular}{|c|c|c|c|c|c|c|c|c|c|c|c|c|c|c|}
\hline $\begin{array}{l}\text { Depth } \\
\text { (ft bls) }\end{array}$ & $\begin{array}{l}\text { SWC } \\
(g / g)\end{array}$ & $\begin{array}{l}\text { MP } \\
(-\mathbf{m})\end{array}$ & $\begin{array}{c}E C \\
(\mathrm{dS} / \mathrm{m})\end{array}$ & $\begin{array}{c}\mathrm{Cl}^{-} \\
(\mathrm{mg} / \mathrm{kg})\end{array}$ & $\begin{array}{c}\mathrm{NO}_{3}-\mathrm{N} \\
(\mathrm{mg} / \mathrm{kg})\end{array}$ & $\begin{array}{c}\mathrm{SO}_{4}-\mathrm{S} \\
(\mathrm{mg} / \mathrm{kg})\end{array}$ & $\begin{array}{c}\mathrm{K} \\
(\mathrm{mg} / \mathrm{kg})\end{array}$ & $\begin{array}{c}\mathrm{Mg} \\
(\mathrm{mg} / \mathrm{kg})\end{array}$ & $\begin{array}{c}\text { Ca } \\
(\mathrm{mg} / \mathrm{kg})\end{array}$ & $\begin{array}{c}\mathrm{Na} \\
(\mathrm{mg} / \mathrm{kg})\end{array}$ & $\begin{array}{l}\text { OM } \\
(\%)\end{array}$ & $\begin{array}{c}\text { Sand } \\
(\%)\end{array}$ & $\begin{array}{l}\text { Silt } \\
(\%)\end{array}$ & $\begin{array}{l}\text { Clay } \\
(\%)\end{array}$ \\
\hline 5 & 0.036 & 2,400 & 0.2 & 9 & 1 & 7 & 72 & 226 & 1,091 & 36 & 0.5 & 81 & 6 & 12 \\
\hline 10 & 0.035 & 8.3 & 0.2 & 7 & 1 & 3 & 18 & 98 & 490 & 26 & 0.4 & 89 & 4 & 6 \\
\hline 15 & 0.047 & 12 & 0.2 & 7 & 1 & 4 & 21 & 95 & 473 & 31 & 0.3 & 92 & 2 & 6 \\
\hline 20 & 0.044 & 11.5 & 0.1 & 4 & 1 & 1 & 16 & 82 & 425 & 24 & 0.3 & 94 & 2 & 4 \\
\hline $30 \mathrm{D}$ & - & - & 0.3 & 14 & 2 & 7 & 123 & 283 & 1,381 & 61 & 0.5 & 66 & 16 & 18 \\
\hline 35 & 0.121 & 15.8 & 0.3 & 18 & 4 & 7 & 117 & 322 & 1,535 & 64 & 0.3 & 76 & 8 & 16 \\
\hline 40 & 0.279 & 10.7 & 0.3 & 11 & 6 & 3 & 64 & 186 & 809 & 44 & 0.4 & 88 & 4 & 8 \\
\hline 45 & 0.12 & 15.1 & 0.3 & 12 & 5 & 2 & 81 & 239 & 988 & 46 & 0.3 & 86 & 4 & 10 \\
\hline 65 & - & - & 0.1 & 5 & 3 & 2 & 157 & 525 & 1,979 & 103 & 0.5 & 58 & 20 & 22 \\
\hline $65 \mathrm{D}$ & 0.174 & 12.3 & 0.2 & 5 & 4 & 1 & 149 & 489 & 1,839 & 96 & 0.4 & 58 & 20 & 22 \\
\hline 70 & 0.1 & 11.2 & 0.1 & 4 & 1 & 2 & 77 & 217 & 875 & 48 & 0.3 & 74 & 10 & 16 \\
\hline $70 \mathrm{D}$ & 0.103 & 7.2 & 0.1 & 5 & 2 & 2 & 94 & 254 & 993 & 57 & 0.3 & 74 & 10 & 16 \\
\hline 75 & 0.08 & - & 0.1 & 9 & 1 & 1 & 36 & 124 & 519 & 34 & 0.3 & 86 & 4 & 10 \\
\hline 80 & 0.075 & 6.6 & 0.2 & 5 & 1 & 1 & 53 & 165 & 745 & 52 & 0.4 & 86 & 6 & 8 \\
\hline 85 & 0.136 & 36.3 & 0.2 & 18 & 1 & 1 & 58 & 173 & 863 & 50 & 0.3 & 78 & 10 & 12 \\
\hline 90 & 0.157 & 9.1 & 0.2 & 9 & 1 & 1 & 86 & 272 & 1,383 & 68 & 0.3 & 88 & 4 & 8 \\
\hline 95 & 0.044 & 38.9 & 0.1 & 9 & 1 & 1 & 49 & 136 & 712 & 42 & 0.2 & 88 & 6 & 6 \\
\hline 125 & 0.064 & 20 & 0.2 & 9 & 1 & 1 & 48 & 147 & 734 & 27 & 0.3 & 90 & 4 & 6 \\
\hline 130 & 0.125 & 25.1 & 0.2 & 9 & 1 & 1 & 92 & 225 & 1,197 & 31 & 0.4 & 70 & 8 & 22 \\
\hline 135 & 0.126 & 20.9 & 0.2 & 9 & 2 & 1 & 89 & 290 & 1,519 & 35 & 0.6 & 72 & 16 & 12 \\
\hline 140 & 0.07 & 16.2 & 0.2 & 7 & 1 & 1 & 78 & 227 & 1,146 & 27 & 0.2 & 86 & 4 & 10 \\
\hline 145 & 0.168 & 38 & 0.1 & 5 & 8 & 2 & 254 & 533 & 2,231 & 51 & 0.8 & 48 & 26 & 26 \\
\hline 150 & 0.119 & 93.3 & 0.2 & 5 & 4 & 2 & 172 & 366 & 1,598 & 47 & 0.5 & 56 & 22 & 22 \\
\hline 155 & 0.193 & 11.5 & 0.1 & 9 & 1 & 2 & 177 & 573 & 2,388 & 54 & 0.7 & 38 & 40 & 22 \\
\hline 160 & 0.085 & 14.8 & 0.2 & 4 & 1 & 2 & 86 & 280 & 1,192 & 29 & 0.3 & 78 & 10 & 12 \\
\hline 165 & 0.09 & 16.6 & 0.1 & 7 & 1 & 2 & 73 & 224 & 939 & 25 & 0.5 & 88 & 2 & 10 \\
\hline 170 & 0.074 & 24 & 0.1 & 9 & 1 & 2 & 84 & 211 & 904 & 35 & 0.6 & 88 & 2 & 10 \\
\hline 175 & 0.053 & 69.2 & 0.2 & 7 & 1 & 1 & 83 & 195 & 829 & 34 & 0.5 & 88 & 2 & 10 \\
\hline 180 & 0.078 & 14.8 & 0.2 & 9 & 1 & 2 & 68 & 155 & 639 & 33 & 0.4 & 80 & 8 & 12 \\
\hline
\end{tabular}


Table 2.2. Soil moisture, texture, and geochemical composition of water extracts from bulk sediment samples at BF-MW-07.

[ft bls, feet below land surface; SWC, soil water content; g/g, grams per gram; MP, matric potential; - m, negative meters of water; EC, electrical conductivity; $\mathrm{dS} / \mathrm{m}$, deciSiemens per meter; $\mathrm{Cl}^{-}$, chloride; $\mathrm{mg} / \mathrm{kg}$, milligrams per kilogram; $\mathrm{NO}_{3}-\mathrm{N}$, nitrate as nitrogen; $\mathrm{SO}_{4}-\mathrm{S}$, sulfate as sulfur; $\mathrm{K}$, potassium; $\mathrm{Mg}$, magnesium; $\mathrm{Ca}$, calcium; $\mathrm{Na}$, sodium; OM, organic material; \%, percent; $\mathrm{D}$, duplicate analysis]

\begin{tabular}{|c|c|c|c|c|c|c|c|c|c|c|c|c|c|c|}
\hline $\begin{array}{l}\text { Depth } \\
\text { (ft bls) }\end{array}$ & $\begin{array}{l}\text { SWC } \\
(g / g)\end{array}$ & $\begin{array}{l}\text { MP } \\
(-\mathrm{m})\end{array}$ & $\begin{array}{c}E C \\
(\mathrm{dS} / \mathrm{m})\end{array}$ & $\begin{array}{c}\mathrm{Cl}^{-} \\
(\mathrm{mg} / \mathrm{kg})\end{array}$ & $\begin{array}{c}\mathrm{NO}_{3}-\mathrm{N} \\
(\mathrm{mg} / \mathrm{kg})\end{array}$ & $\begin{array}{c}\mathrm{SO}_{4}-\mathrm{S} \\
(\mathrm{mg} / \mathrm{kg})\end{array}$ & $\begin{array}{c}\mathrm{K} \\
(\mathrm{mg} / \mathrm{kg})\end{array}$ & $\begin{array}{c}\mathrm{Mg} \\
(\mathrm{mg} / \mathrm{kg})\end{array}$ & $\begin{array}{c}\mathrm{Ca} \\
(\mathrm{mg} / \mathrm{kg})\end{array}$ & $\begin{array}{c}\mathrm{Na} \\
(\mathrm{mg} / \mathrm{kg})\end{array}$ & $\begin{array}{l}\text { OM } \\
(\%)\end{array}$ & $\begin{array}{c}\text { Sand } \\
(\%)\end{array}$ & $\begin{array}{l}\text { Silt } \\
(\%)\end{array}$ & $\begin{array}{l}\text { Clay } \\
(\%)\end{array}$ \\
\hline 5 & 0.062 & 77.6 & 0.2 & 4 & 1 & 1 & 53 & 202 & 870 & 27 & 0.4 & 88 & 6 & 6 \\
\hline 10 & 0.058 & 9.8 & 0.2 & 5 & 1 & 1 & 50 & 151 & 663 & 35 & 0.5 & 88 & 4 & 8 \\
\hline $10 \mathrm{D}$ & 0.055 & 14.5 & 0.2 & 5 & 1 & 1 & 51 & 154 & 678 & 35 & 0.2 & 88 & 6 & 6 \\
\hline 15 & 0.084 & 8.5 & 0.1 & 2 & 1 & 2 & 28 & 120 & 717 & 38 & 0.3 & 88 & 4 & 8 \\
\hline 20 & 0.051 & 11.7 & 0.2 & 2 & 1 & 2 & 21 & 70 & 450 & 34 & 0.2 & 90 & 6 & 4 \\
\hline 25 & 0.051 & 5.2 & 0.2 & 5 & 1 & 3 & 17 & 58 & 439 & 34 & 0.1 & 94 & 2 & 4 \\
\hline 30 & 0.07 & 7.4 & 0.2 & 14 & 2 & 3 & 29 & 83 & 519 & 54 & 0.2 & 79 & 9 & 12 \\
\hline 35 & 0.235 & 39.8 & 0.2 & 9 & 1 & 2 & 54 & 156 & 901 & 76 & 0.7 & 78 & 8 & 14 \\
\hline 40 & 0.208 & 83.2 & 0.2 & 5 & 1 & 1 & 31 & 96 & 543 & 45 & 0.3 & 88 & 4 & 8 \\
\hline 45 & 0.105 & 15.1 & 0.1 & 14 & 1 & 1 & 69 & 195 & 990 & 66 & 0.3 & 78 & 4 & 18 \\
\hline 50 & 0.085 & 15.8 & 0.2 & 7 & 1 & 2 & 68 & 218 & 1,095 & 69 & 0.6 & 78 & 4 & 18 \\
\hline $50 \mathrm{D}$ & 0.094 & 13.5 & 0.2 & 9 & 1 & 2 & 72 & 230 & 1,143 & 73 & 0.5 & 80 & 4 & 16 \\
\hline 55 & 0.064 & 16.6 & 0.2 & 18 & 1 & 2 & 59 & 207 & 989 & 57 & 0.6 & 78 & 8 & 14 \\
\hline 60 & 0.068 & 23.4 & 0.1 & 9 & 1 & 2 & 97 & 139 & 684 & 36 & 0.5 & 84 & 4 & 12 \\
\hline 65 & 0.042 & 17.8 & 0.1 & 9 & 1 & 1 & 58 & 138 & 660 & 29 & 0.5 & 86 & 6 & 8 \\
\hline 70 & 0.047 & 30.9 & 0.1 & 7 & 1 & 2 & 41 & 159 & 757 & 28 & 0.4 & 86 & 6 & 8 \\
\hline 75 & 0.073 & 38.9 & 0.1 & 9 & 1 & 2 & 51 & 188 & 914 & 28 & 0.6 & 72 & 12 & 16 \\
\hline 80 & 0.1 & 4.9 & 0.1 & 4 & 1 & 2 & 76 & 228 & 1,120 & 29 & 0.4 & 68 & 14 & 18 \\
\hline 85 & 0.041 & 45.7 & 0.1 & 2 & 1 & 1 & 40 & 119 & 563 & 20 & 0.4 & 87 & 2 & 10 \\
\hline 90 & 0.081 & 13.2 & 0.1 & 5 & 1 & 1 & 53 & 190 & 882 & 24 & 0.8 & 77 & 10 & 12 \\
\hline 95 & 0.097 & 11.7 & 0.1 & 7 & 1 & 2 & 72 & 264 & 1,212 & 31 & 0.4 & 73 & 4 & 22 \\
\hline 100 & 0.104 & 7.9 & 0.2 & 5 & 1 & 3 & 75 & 213 & 1,005 & 27 & 0.4 & 73 & 10 & 16 \\
\hline 105 & 0.06 & 33.9 & 0.1 & 9 & 1 & 2 & 46 & 185 & 869 & 23 & 0.4 & 81 & 6 & 12 \\
\hline 110 & 0.053 & 33.9 & 0.1 & 7 & 1 & 2 & 54 & 193 & 888 & 25 & 0.3 & 81 & 6 & 12 \\
\hline 115 & 0.071 & 14.1 & 0.2 & 9 & 1 & 2 & 75 & 252 & 1,115 & 25 & 0.7 & 73 & 4 & 22 \\
\hline 120 & 0.115 & 9.5 & 0.2 & 7 & 1 & 2 & 75 & 251 & 1,103 & 22 & 0.7 & 73 & 4 & 22 \\
\hline 125 & 0.083 & 33.9 & 0.1 & 7 & 2 & 2 & 54 & 183 & 787 & 17 & 0.5 & 85 & 2 & 12 \\
\hline $125 \mathrm{D}$ & 0.077 & 23.4 & 0.1 & 4 & 1 & 1 & 46 & 161 & 712 & 17 & 0.1 & 83 & 4 & 12 \\
\hline 130 & 0.088 & 70.8 & 0.1 & 5 & 1 & 2 & 75 & 226 & 1,004 & 19 & 0.7 & 75 & 6 & 18 \\
\hline 135 & 0.097 & 25.7 & 0.1 & 9 & 1 & 2 & 71 & 233 & 1,055 & 22 & 0.5 & 75 & 8 & 16 \\
\hline 140 & 0.084 & 52.5 & 0.1 & 9 & 1 & 3 & 91 & 297 & 1,378 & 29 & 0.3 & 69 & 8 & 22 \\
\hline 145 & 0.134 & 120.2 & 0.1 & 5 & 1 & 3 & 123 & 339 & 1,454 & 28 & 0.5 & 67 & 10 & 22 \\
\hline 150 & 0.088 & 7.9 & 0.1 & 9 & 1 & 3 & 73 & 213 & 935 & 23 & 0.7 & 77 & 10 & 12 \\
\hline 155 & 0.067 & 851.1 & 0.2 & 14 & 2 & 2 & 62 & 166 & 737 & 29 & 0.4 & 79 & 8 & 12 \\
\hline 160 & 0.091 & 39.8 & 0.2 & 7 & 1 & 2 & 93 & 323 & 1,349 & 24 & 0.6 & 77 & 4 & 18 \\
\hline 165 & 0.095 & 20.9 & 0.1 & 7 & 1 & 2 & 99 & 257 & 1,029 & 27 & 0.4 & 73 & 4 & 22 \\
\hline 170 & 0.078 & 19.1 & 0.1 & 9 & 1 & 2 & 71 & 211 & 851 & 28 & 0.5 & 83 & 4 & 12 \\
\hline 175 & 0.104 & 91.2 & 0.1 & 7 & 1 & 3 & 109 & 368 & 1,515 & 25 & 0.9 & 66 & 9 & 25 \\
\hline $175 \mathrm{D}$ & 0.084 & 109.6 & 0.1 & 5 & 1 & 2 & 111 & 369 & 1,541 & 27 & 0.8 & 61 & 14 & 24 \\
\hline 180 & 0.132 & 14.1 & 0.2 & 5 & 1 & 2 & 106 & 308 & 1,300 & 27 & 0.5 & 65 & 12 & 22 \\
\hline
\end{tabular}


Table 2.3. Soil moisture, texture, and geochemical composition of water extracts from core samples.

[ft bls, feet below land surface; BD, bulk density; $\mathrm{g} / \mathrm{cm}^{3}$, grams soil per cubic centimeter; SWC, soil water content; $\mathrm{m}^{3} / \mathrm{m}^{3}$, cubic meter per cubic meter; EC, electrical conductivity; $\mathrm{dS} / \mathrm{m}$, deciSiemens per meter; $\mathrm{Cl}$, chloride; $\mathrm{mg} / \mathrm{kg}$, milligrams per kilogram; $\mathrm{NO}_{3}-\mathrm{N}$, nitrate as nitrogen; $\mathrm{SO}_{4}-\mathrm{S}$, sulfate as sulfur; $\mathrm{K}$, potassium; Mg, magnesium; Ca, calcium; Na, sodium; OM, organic material; \%, percent; BF-MW, Bedell Flat-Monitoring Well]

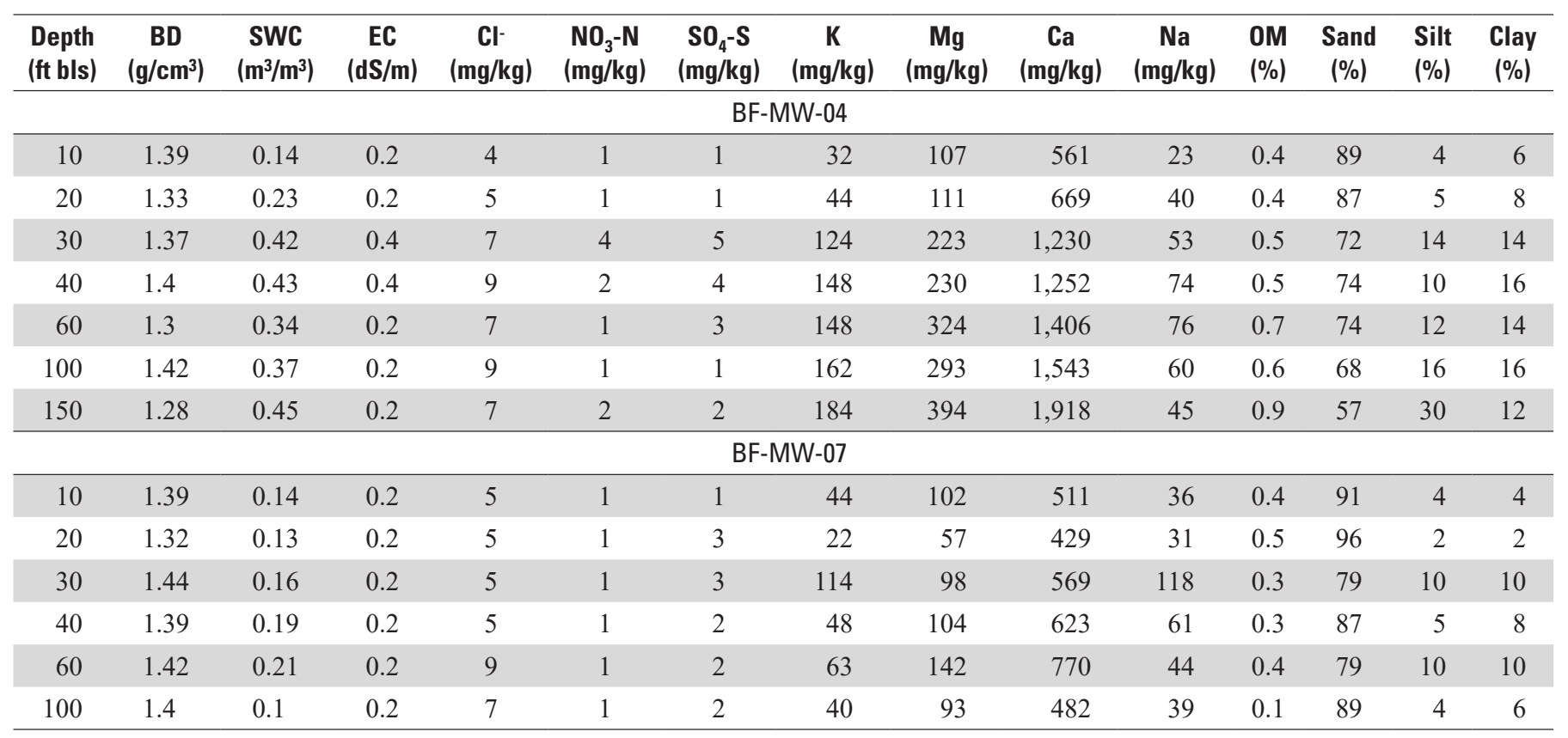




\section{Appendix 3. Chip Trays from Roto-Sonic Boreholes}

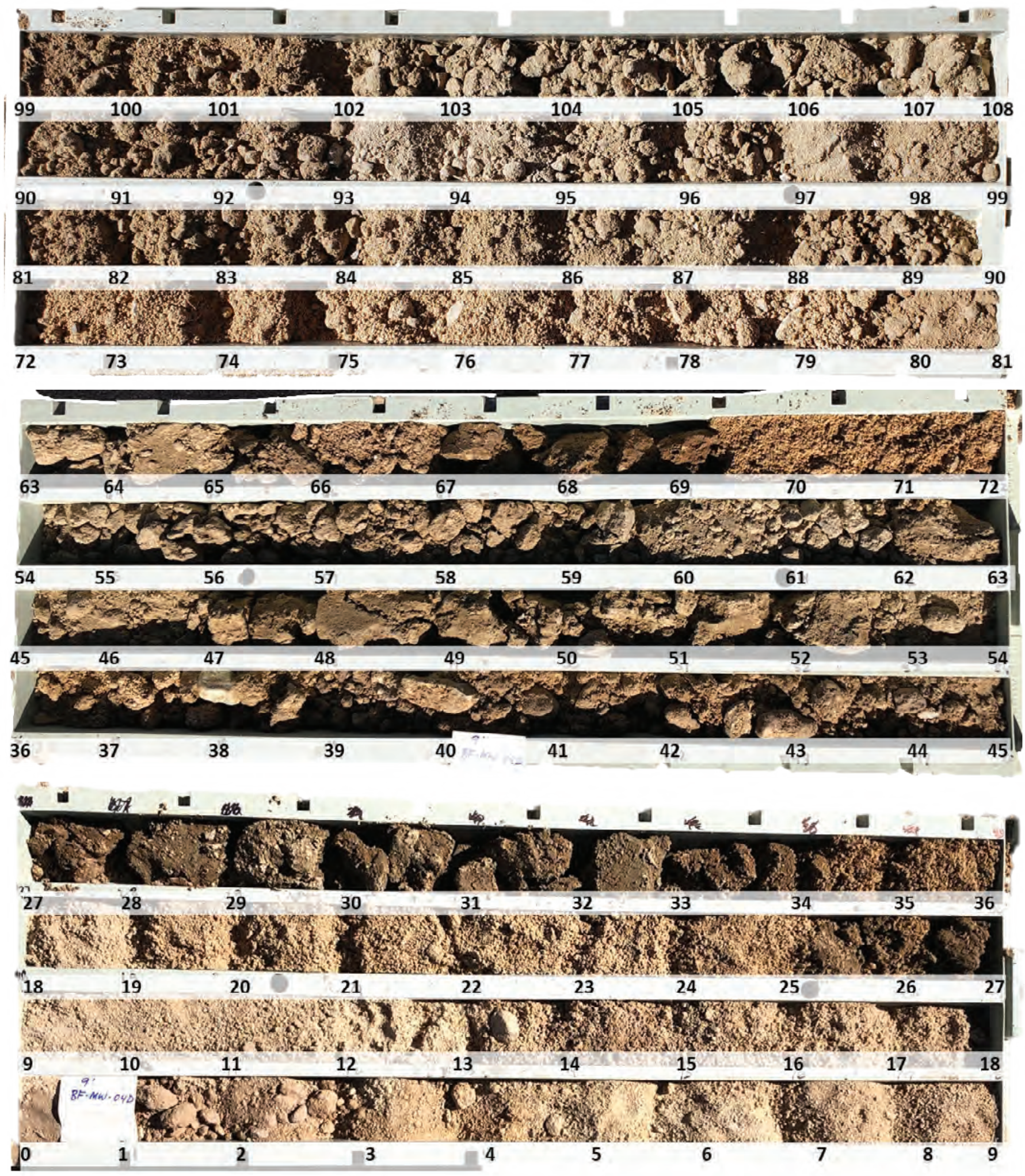

Figure 3.1. BF-MW-04 from surface to 108 feet below land surface. 


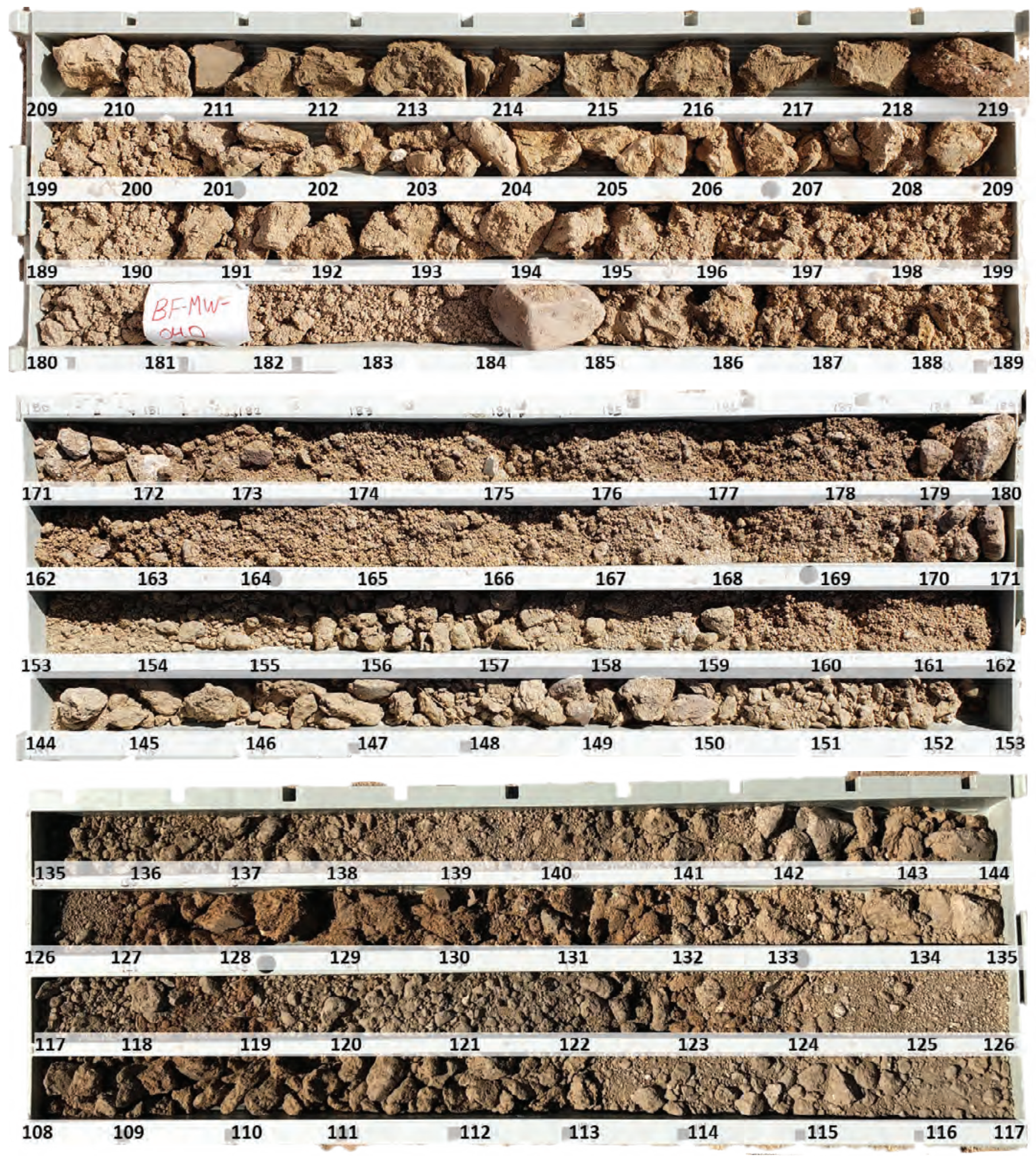

Figure 3.2. BF-MW-04 from 108 to 219 feet below land surface. 


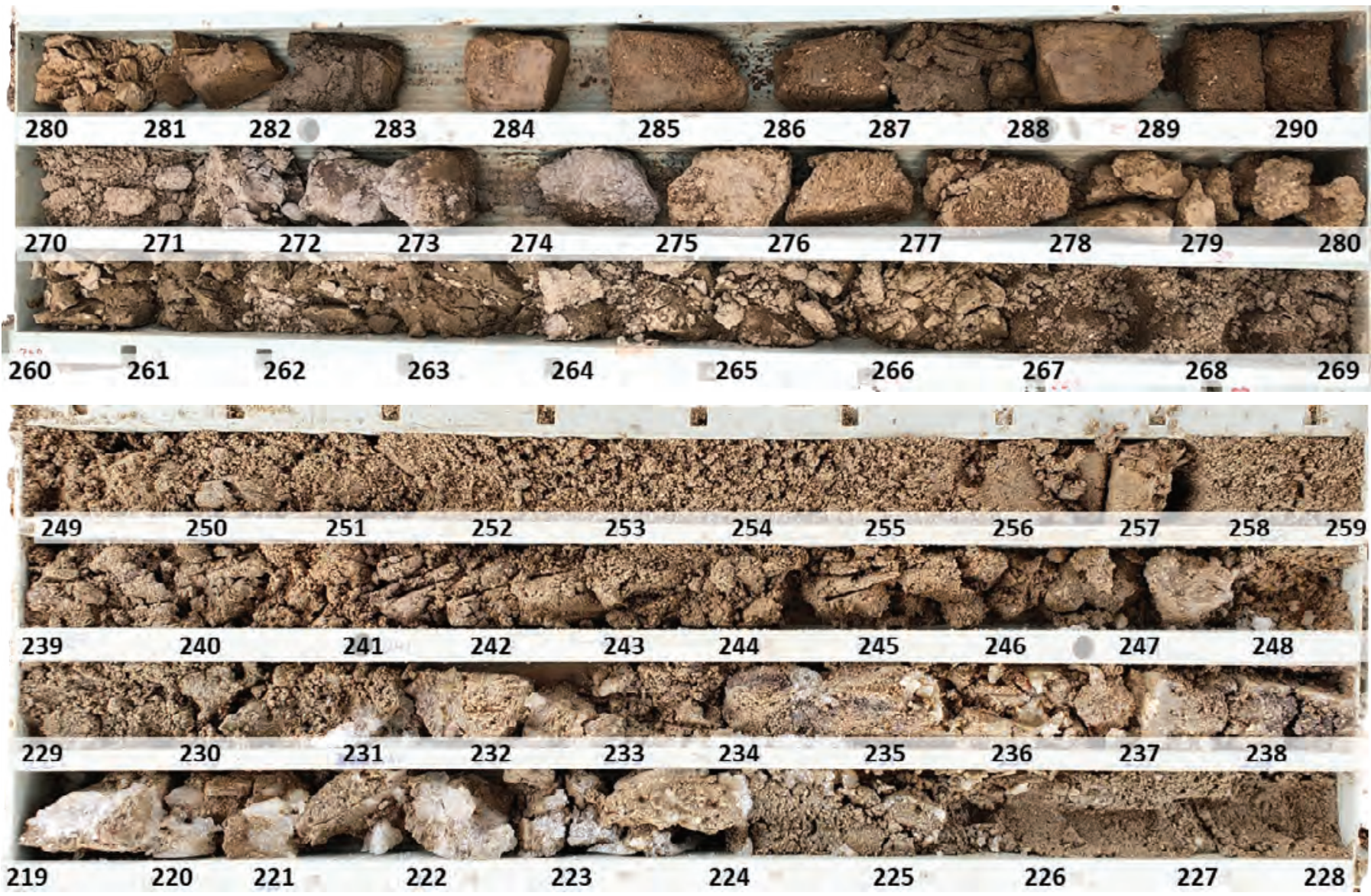

Figure 3.3. BF-MW-04 from 219 to 290 feet below land surface. 

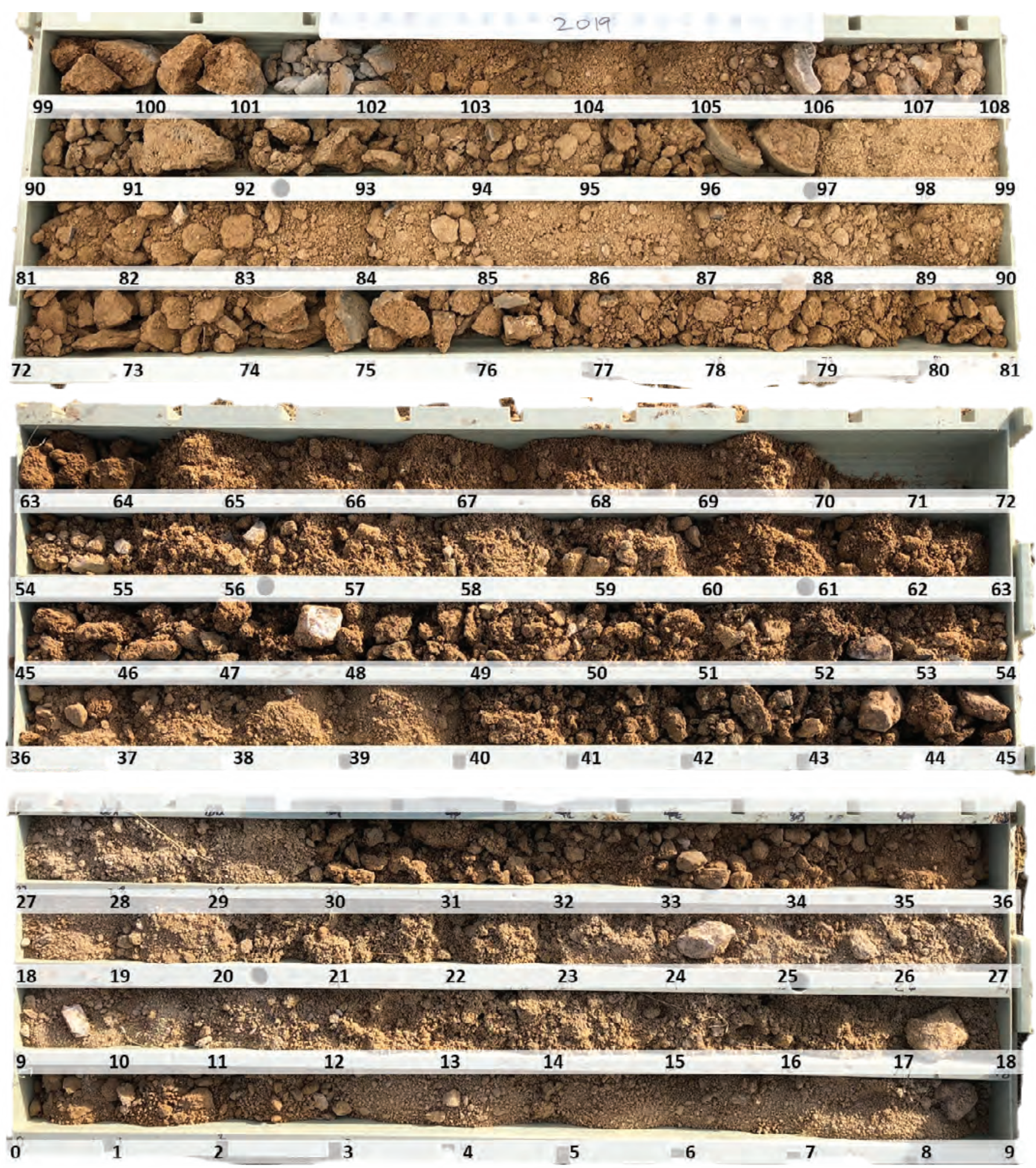

Figure 3.4. BF-MW-07 from surface to 108 feet below land surface. 


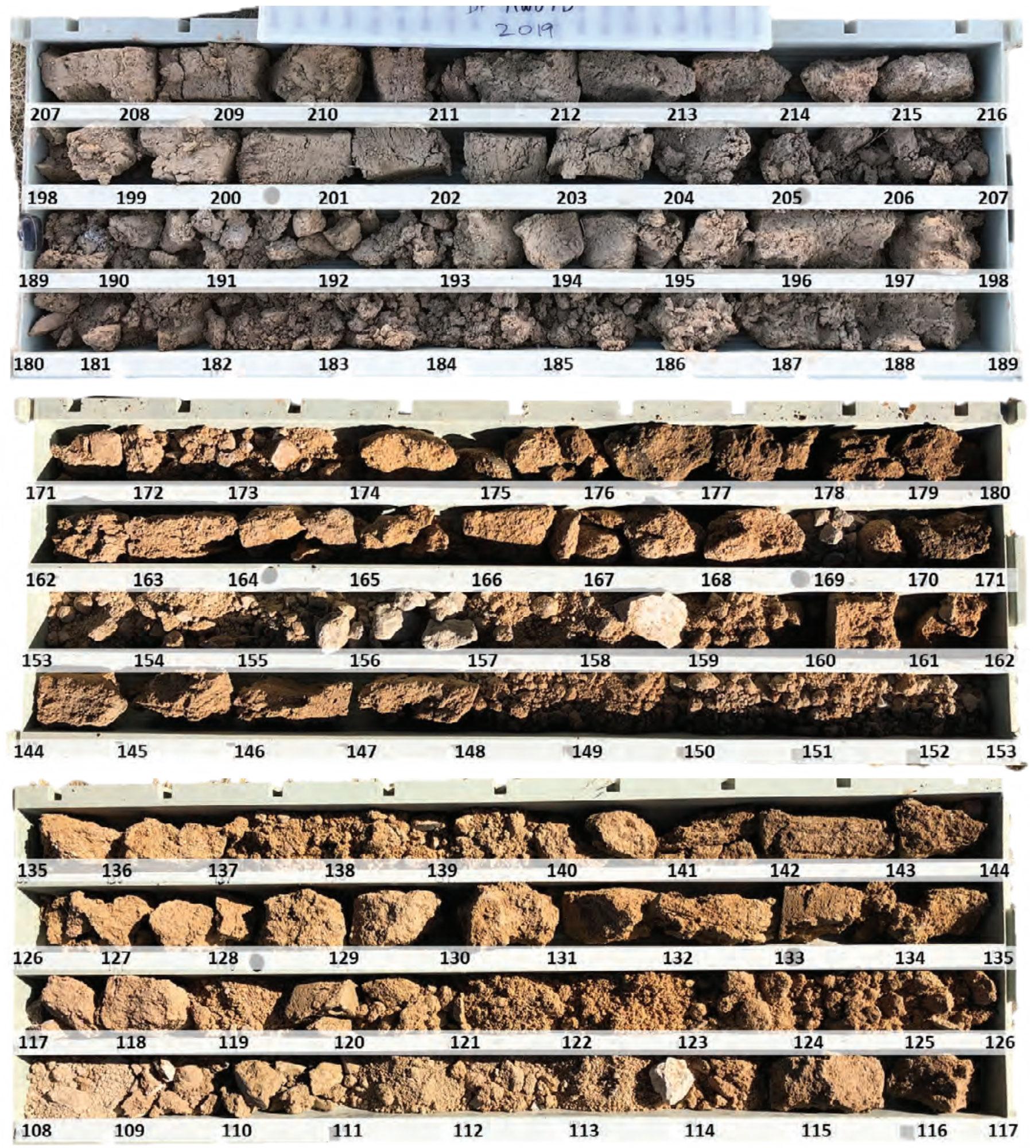

Figure 3.5. BF-MW-07 from 108 to 216 feet below land surface. 


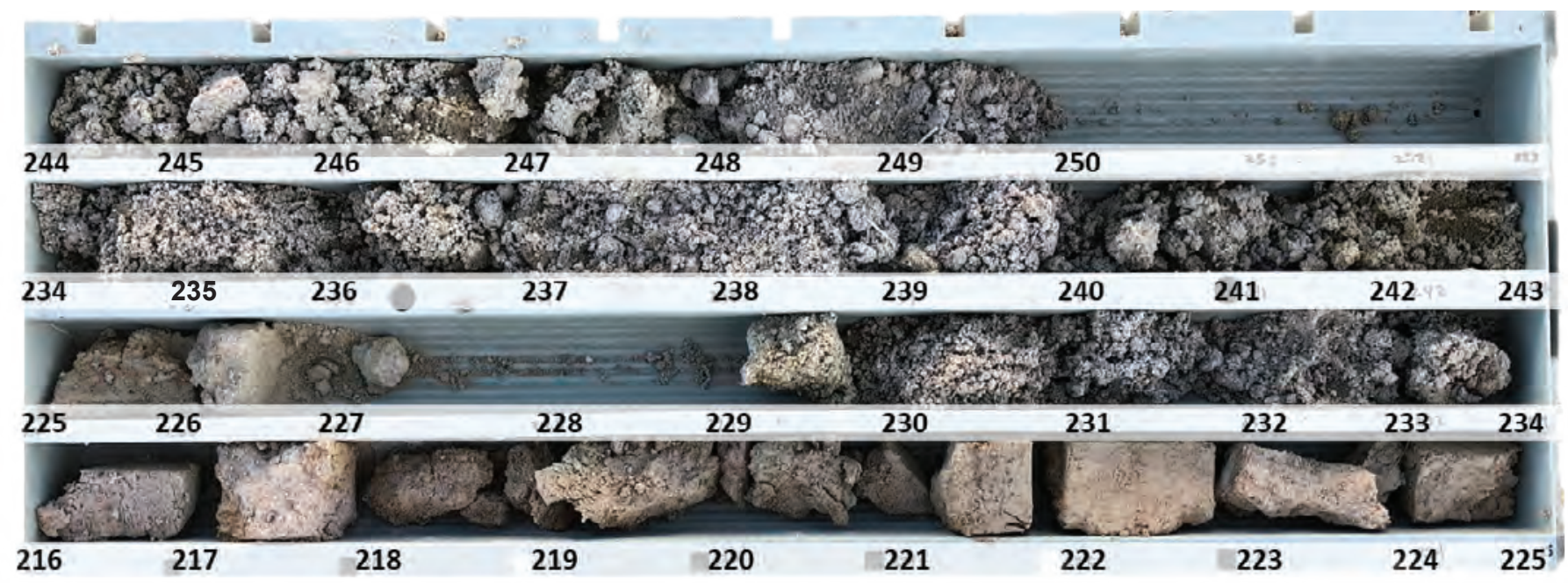

Figure 3.6. BF-MW-07 from 216 to 250 feet below land surface. 


\section{Appendix 4. Field Procedure for Roto-Sonic Borehole Field Characterization}

Ten-foot (ft) sections of cuttings come out in approximately 2-ft intervals per bag.

1. Use a HydroSense Soil Water Content Probe with 12-centimeter sensor.

o Insert sensors completely into soil bags for every $\mathrm{ft}$ of extruded core

o Hit 'Store data' being sure to hit 'ok' if 'no GPS lock' message appears

o Write water content, period, and time on the HydroSense field data sheet

2. Cut open bag to expose the soil—use a spatula to expose the center of core-ignore the edges.

3. Collect bulk sediment sample at $5 \mathrm{ft}$ intervals.

o Write the 'BF-MW-number-zz' and sampling date on the bag in two spots

o Use a spatula to sample extruded core center

o Collect one-eighth of the large sample bag - about 2 cups of sediment

4. Complete the hand-texture classification ball and ribbon test.

o Note the textural breaks in each extruded bag

o Form a ball, then ribbon, then wet a pinch of soil

o Note the textural classification on the sheet: sand (S), loamy sand (LS), sandy loam (SL), sandy clay loam (SaCL), silty clay loam ( $\mathrm{SiCL})$, etc.

o Note if the sand is fine, medium, or coarse grained

o Are there gravels? If so, note rock type (granite, quartzite, andesite, and tuff), angularity, and general size

o Is the material loose, soft, hard, or rigid?

o Note all of the answers on the Borehole Log data sheet.

5. Use a spatula to obtain 1-ft interval samples for the core trays.

o If it is rigid, cut the soil block to fit the tray.

o Center sample in core tray at appropriate depth below land surface

o Once a core tray is full, take a picture with a sign indicating the well name and spread tray evenly on surface

6. Take a chip tray sample every $10 \mathrm{ft}$ that typifies the bulk texture of that section for Truckee Meadows Water Authority (TMWA).

7. Collect the split spoon core at specific intervals at 10,20,30,40,60, and $100 \mathrm{ft}$ below land surface.

o Note the blow counts from the driller on the HydroSense Sheet for each of three, 6-inch sections.

o Drillers will lay the core out and denote the orientation with an arrow toward land surface.

o Carefully slice and cap the best 'full' core from the three sections, noting which one was selected

o Write the well identification and depth on each cap and on the brass body of the core

o Seal each cap with electrical tape

o Put it in a secondary plastic bag with other cores from that borehole, seal secondary bag when full (approximately six cores) 


\section{Appendix 5. Field Textural Lookup Table}

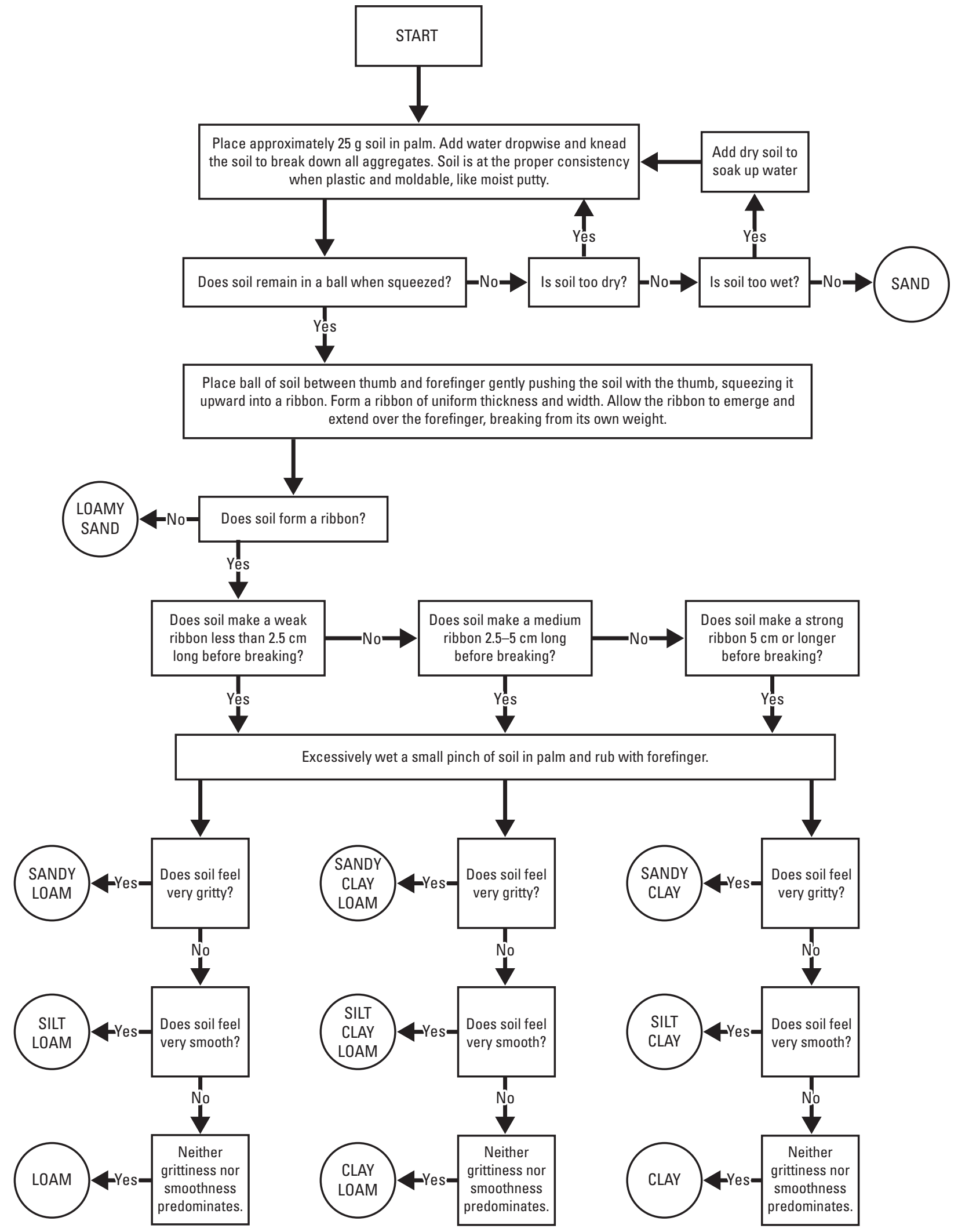

Figure 5.1. Ball and ribbon hand texturing flow chart from the U.S. Department of Agriculture-Natural Resource Conservation Service (USDA-NRCS), adapted from Thien (1979). 
Table 5.1. The U.S. Department of Agriculture (USDA) size ranges for each textural class and lookup table values applied to field characterization.

[*Indicates mean size classes derived from laboratory analyses. Other classes were estimated.]

\begin{tabular}{|c|c|c|c|c|c|c|c|c|}
\hline & \multicolumn{4}{|c|}{ Range percent } & \multicolumn{4}{|c|}{ Lookup values for field characterization } \\
\hline & Sand & Silt & Clay & Textural class & Abbreviation & Sand & Silt & Clay \\
\hline \multirow[t]{2}{*}{ Sandy soils } & $86-100$ & $0-14$ & $0-10$ & Sand & $\mathrm{S}^{*}$ & 90.5 & 3.9 & 5.6 \\
\hline & $70-86$ & $0-30$ & $0-15$ & Loamy sand & $\mathrm{LS}^{*}$ & 86 & 4.3 & 9.7 \\
\hline Loamy soils & $50-70$ & $0-50$ & $0-20$ & Sandy loam & $\mathrm{SL}^{*}$ & 75.1 & 10.4 & 14.5 \\
\hline \multirow{3}{*}{$\begin{array}{l}\text { Loamy soils } \\
\text { (medium } \\
\text { texture) }\end{array}$} & $23-52$ & $28-50$ & $7-27$ & Loam & $\mathrm{L}$ & 42 & 36 & 22 \\
\hline & $20-50$ & $74-88$ & $0-27$ & Silty loam & $\mathrm{SiL}$ & 10 & 80 & 10 \\
\hline & $0-20$ & $88-100$ & $0-12$ & Silt & $\mathrm{Si}$ & 5 & 90 & 5 \\
\hline \multirow{3}{*}{$\begin{array}{l}\text { Loamy soils } \\
\text { (more fine } \\
\text { texture) }\end{array}$} & $20-45$ & $15-52$ & $27-40$ & Clay loam & CL & 30 & 38 & 32 \\
\hline & $45-80$ & $0-28$ & $20-35$ & Sandy clay loam & $\mathrm{SaCL}^{*}$ & 65.1 & 11.8 & 23.1 \\
\hline & $0-20$ & $40-73$ & $27-40$ & Silty clay loam & $\mathrm{SiCL}$ & 15 & 55 & 30 \\
\hline \multirow{3}{*}{$\begin{array}{l}\text { Clayey soils } \\
\text { (fine } \\
\text { texture) }\end{array}$} & $45-65$ & $0-20$ & $35-55$ & Sandy clay & $\mathrm{SaC}$ & 60 & 15 & 25 \\
\hline & $0-20$ & $40-60$ & $40-60$ & Silty clay & $\mathrm{SiC}$ & 20 & 40 & 40 \\
\hline & $0-45$ & $0-40$ & $40-100$ & Clay & $\mathrm{C}$ & 35 & 20 & 45 \\
\hline
\end{tabular}


For more information concerning the research in this report, contact the

Nevada Water Science Center

U.S. Geological Survey

2730 N. Deer Run Road

Carson City, Nevada 89701

https://www.usgs.gov/centers/nv-water

Publishing support provided by the U.S. Geological Survey

Science Publishing Network, Sacramento Publishing Service Center 


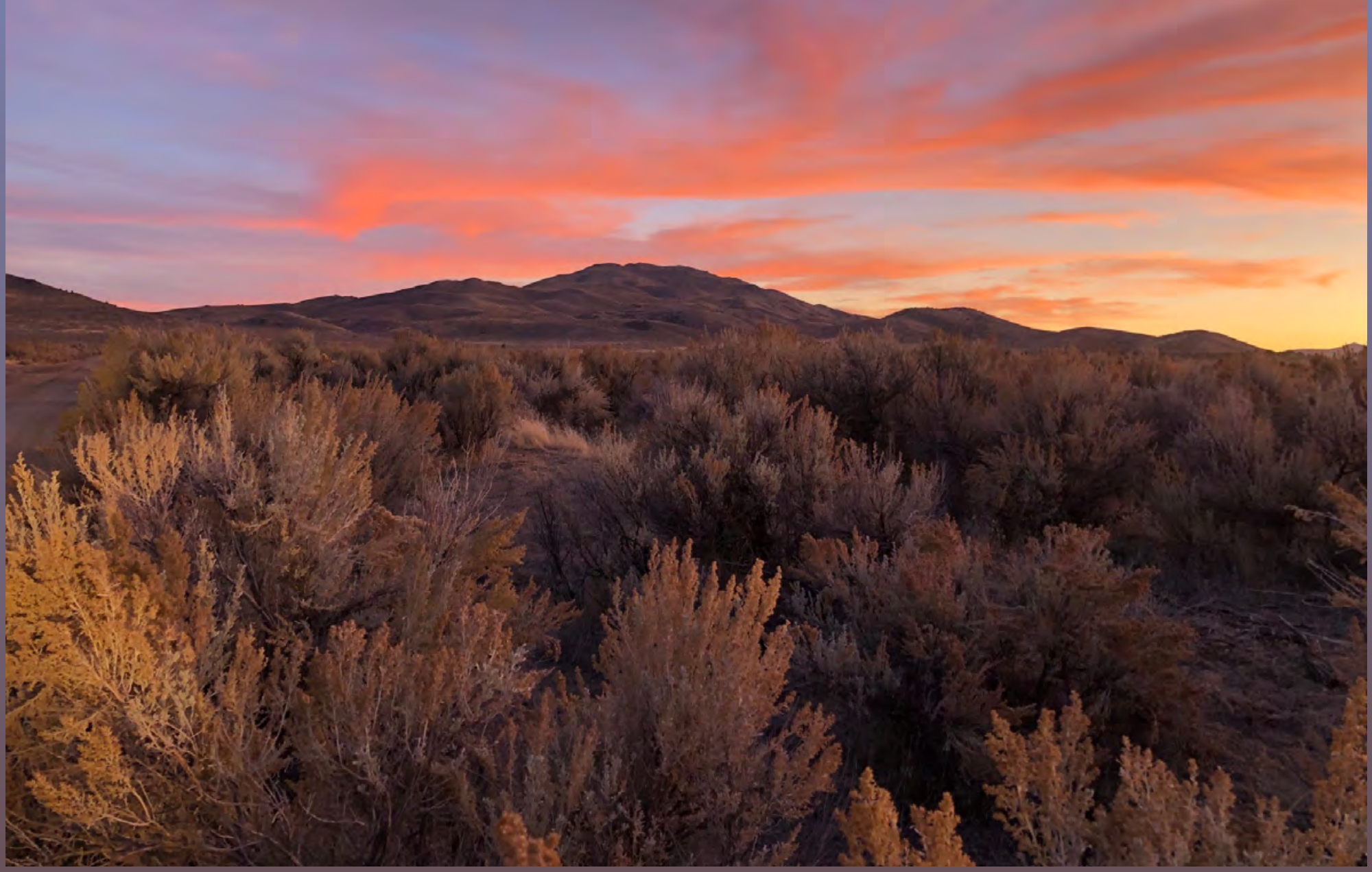

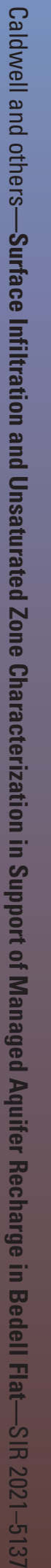

